\title{
A Source Rock
}

evaluation of the

Mesozoic Sediments of the Well Hyllebjerg-1 Danish Subbasin

By Birthe J. Schmidt
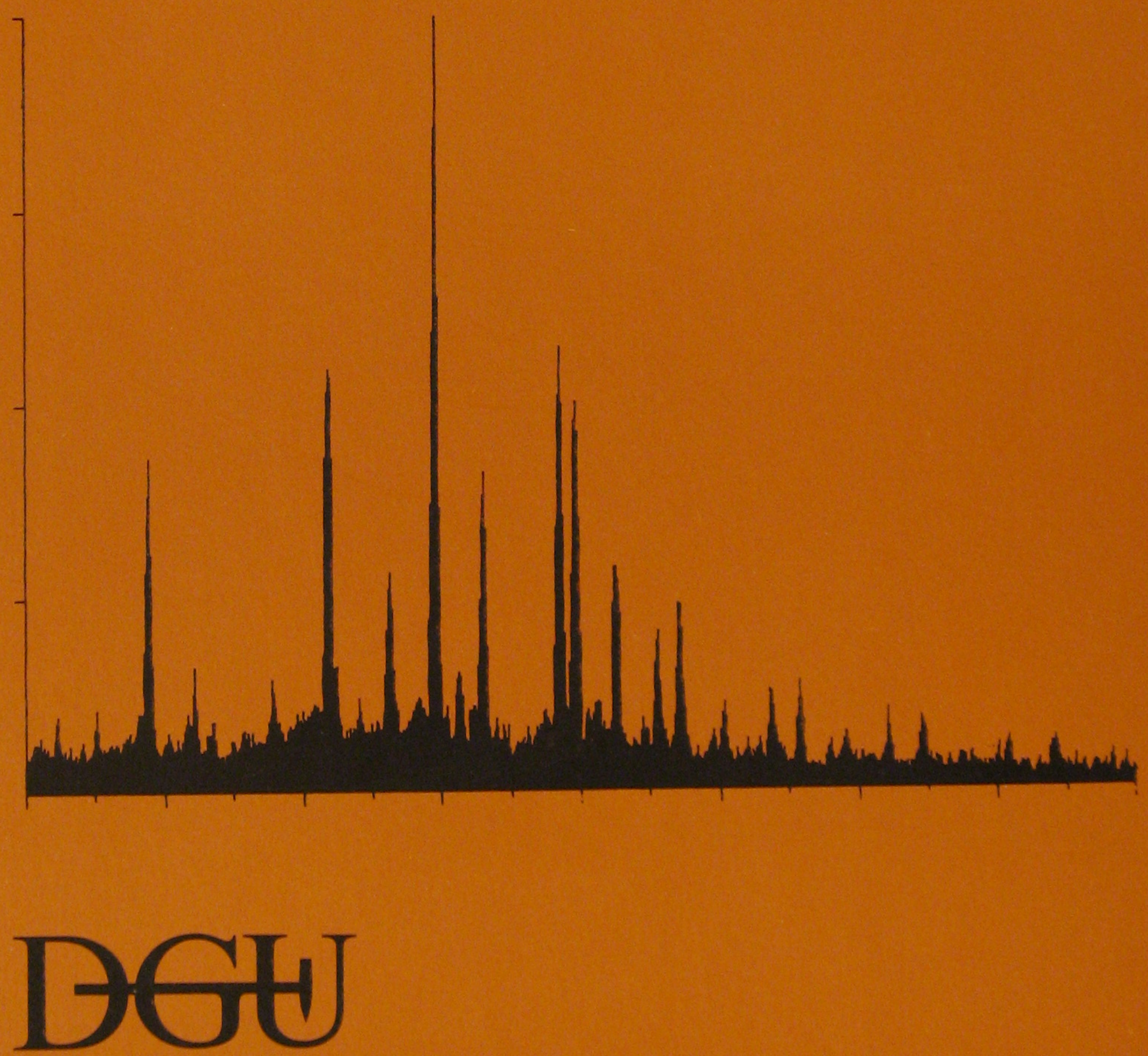

Geological Survey of Denmark

Ministry of the Environment

1988 
A Source Rock evaluation of the

- Mesozoic Sediments of the Well Hyllebjerg-1 Danish Subbasin

By Birthe J. Schmidt

April 1988

DGU series C. no. 9 
Keywords :

Danish Subbasin, Mesozoic, Hydrocarbon deposits and sedimentary rocks

DGU serie $C$ no. 9

ISBN 87-88640-24-8

ISSN 0900-6362

Printed in 750 copies

Printed at DGU

DGU 1988-05-01

Received: Oct. 1986

Birthe J. Schmidt

Institute of Geology,

University of Aarhus,

DK-8000 Arhus C.

Denmark

(C) Geological Survey of Denmark

Thoravej 8, DK-2400 Copenhagen NV, Denmark 
Contents

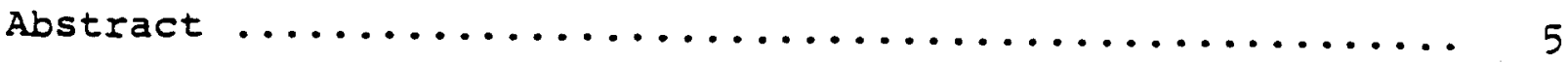

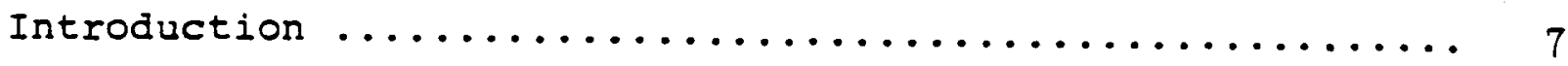

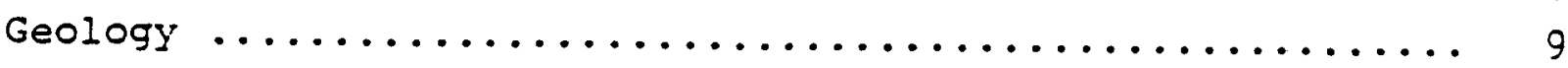

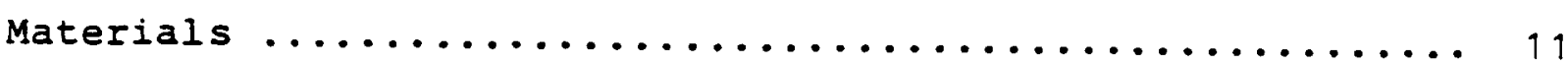

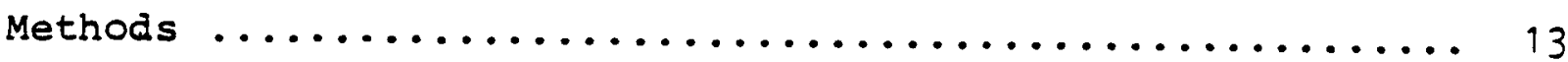

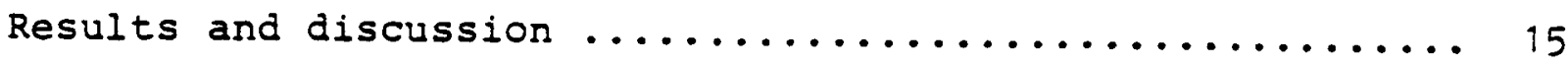

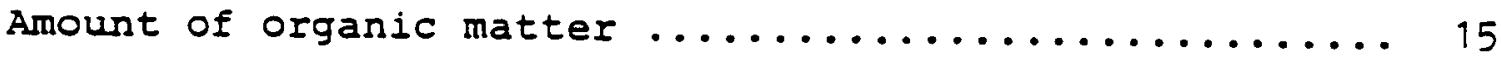

Composition of the organic matter ............. 17

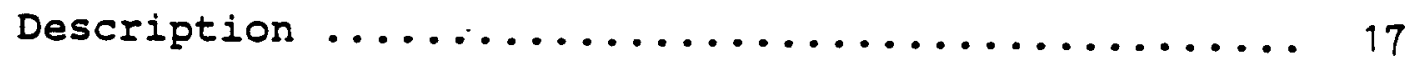

Hydrocarbon potential .................... 21

Vitrinite reflectance measurements ............... 24

spectral fluorescence measurements ............... 29

Extractable organic matter and chromatographic

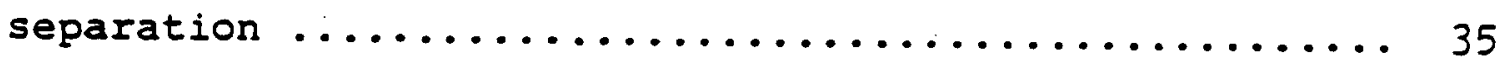

Gas chromatography ..................... 37

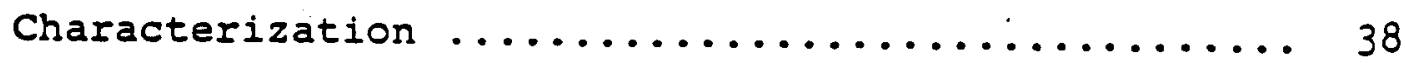

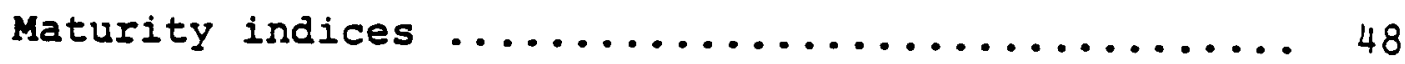

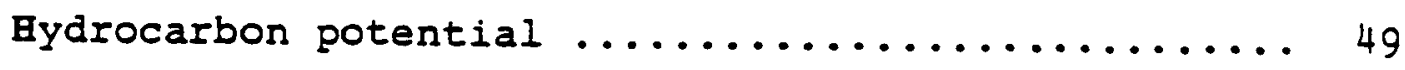

Gas chromatography - mass spectrometry of biomarkers .. 51

Conclusion ............................. 56

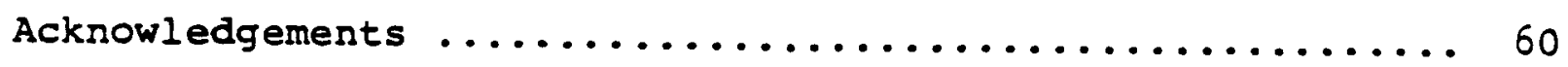

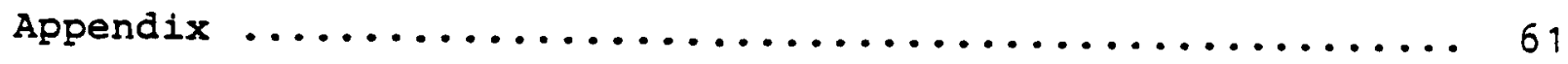

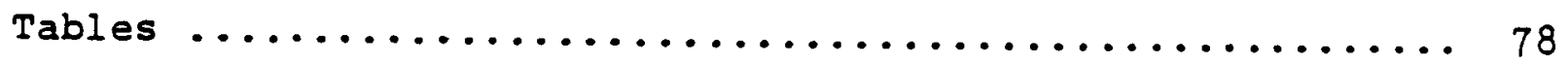

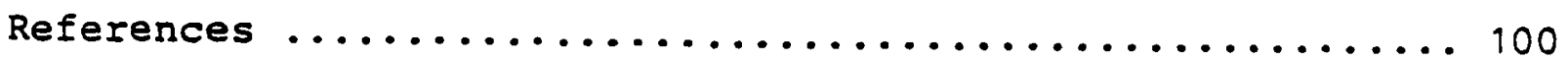


ABSTRACT

The source rock potential of Mesozoic sediments (cuttings) from the Hyllebjerg 1 well, Danish Subbasin, has been assesed using a number of different petrographical and organochemical methods.

Upper Jurassic sediments (Bream Formation) equivalent to the principal source rocks of the North Sea graben structures (Kimmeridge Clay Formation and lateral equivalents) do not show similar prominent source rock characteristics in this well, although a higher proportion of algal material is observed.

Sediments with the most promising source rock characteristics for liquid hydrocarbons were detected mainly in the lower Jurassic sequences of the upper Fjerritslev Formation (F-4 and upper F-3 Member) and in one horizon in the Upper Cretaceous Vedsted Formation which showed a good quality composition and a relatively high content of organic matter. But these sediments may be excluded as actual source rocks in this well as maturity (assuming the threshold value near $0.60 \% R_{0}$ ) is eirst reached at approximately $8500^{\circ}$ depth i.e. at the top of the Gassum Formation (Upper Triassic/Lower Jurassic). The conditions may only by sightly different off - structure is this area, as the F-4 and F-3 Member sequence according to seismic sections is found at approximately the same depth. But the depth to (and the thickness of) the Fjerritslev Formation is increasing towards the SE into the rimsynclines of the saltdomes nearby. While sufficient maturity is reached in the deeper part of the well, no commercial accumulations of hydrocarbons were encountered. This is attributed to the mainly reworked, unfavourable type of organic matter and the generally decreasing organic content downwards in the well, approaching 
the lower limit for potential source rocks (set at $0,5 \%$ $T O C)$. However, generation and migration of small amounts of gaseous hydrocarbons from Gassum Formation sediments containing more humic-influenced organic matter with only minor reworking cannot generally be excluded either here or elsewhere in the basin. Some more attention should also be paid to the Vinding Formation sediments which contain some algae-rich (Botryocous-type) oil-prone horizons of more favourable source rock conditions.

Mature sediments are found at shallower depths ( $\left.8500^{\prime}\right)$ in this well in the central part of the basin compared to the more marginal areas $\left(8900^{\circ}\right)$ where a slightly higher geothermal gradient in Hyllebjerg $1\left(28^{\circ} \mathrm{C} / \mathrm{km}\right.$ uncorrected) is seen compared with the marginal areas $\left(23.5^{\circ} \mathrm{C} / \mathrm{km}\right.$ uncorrected) away from the basinal depocenter. The basinal depocenter also has a higher heat flow. 
This investigation on the well Hyllebjerg 1 forms part of the larger EFP-85 project "Maturity analyses of the sediments in the Danish Subbasin". The purpose of the project is to investigate the source rock potential of the released deeper wells from the Danish off-shore area (outside the Central Graben), supplemented by a well from the central art of the on-shore area of the Danish Subbasin. Most of the other on-shore wells have been investigated and their oil/gas potential has been estimated (Thomsen et al. 1983, Thomsen et al. 1987).

With financial support for 6 months work initially granted by the Danish Ministry of Energy (EFP-projekt - aktst. 118, 1983) the investigation started in 1984 with a detailed analysis of the well Hyllebjerg 1 . The results from Hyllebjerg 1 will contribute essentially to knowledge of the maturity conditions of the Mesozoic sequence of the central on-shore part of the Danish Subbasin, which is generally characterized by relatively high geothermal gradients and some sequences of potential hydrocarbon source rocks.

This report is based on the data available at the end of the short project period, supplemented with analyses performed at the Rheinisch-Westfalische Technische Hochschule in Aachen (F.R.G.) in the spring of 1985 (grant support by SNF) and completed under EFP -85 . 
3
10
0
0
0
5
0
0
0
5
0
0
0
0
9
5
5
0
0
4
0
5
09
0

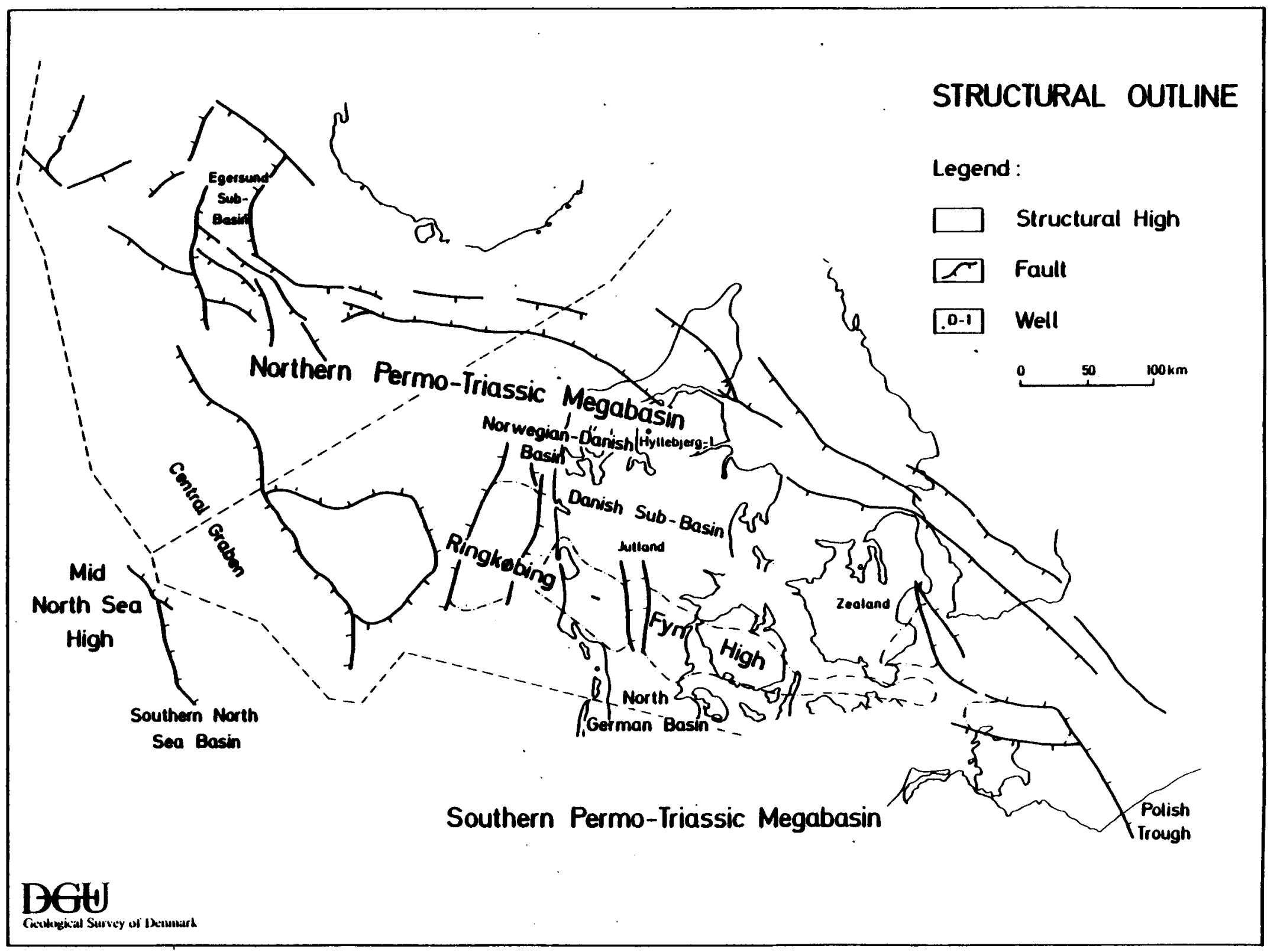


The well Hyllebjerg 1 was drilled as an exploration well on a low relief collapse structure (solution of salt from Oddesund Formation) in $1975 / 76$ to a depth of 2883 m (b. KB) in the central part of the Danish Subbasin (fig.1) It encountered thick sequences of Mesozoic sediments; $1485 \mathrm{~m}$ of Triassic, Jurassic and Lower Cretaceous sediments occurred in the investigated sequence.

The regional and stratigraphic aspects and environments of deposition in the Danish area are described in detail by Larsen (1966), Christensen (1974), Michelsen (1975, 1978), Bertelsen $(1978,1980)$ and Koch (1983). The lithostratigraphic division used here is based on wire line logs (DGU, unpublished results). Well data are published in the Well Data Summary Sheets vol. 2 (1981). The general lithostratigraphy showing the formations and members encountered in the investigation is seen in $\mathrm{fig} .2$. 


\section{PRE-TERTIARY LITHOSTRATIGRAPHY}

\begin{tabular}{|c|c|c|}
\hline \multirow{12}{*}{ 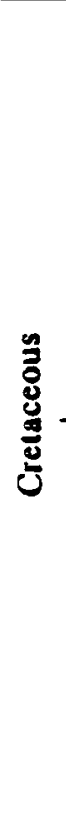 } & & Maastrichtian \\
\hline & \multirow{5}{*}{$\begin{array}{l}\overrightarrow{\mathrm{D}} \\
\text { 을 }\end{array}$} & Campanian \\
\hline & & Santonian \\
\hline & & Coniacian \\
\hline & & Turonian \\
\hline & & Cenomanian \\
\hline & \multirow{6}{*}{ 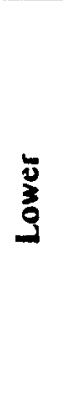 } & Albian \\
\hline & & Aptian \\
\hline & & Barremian \\
\hline & & Hauterivian \\
\hline & & Valanginian \\
\hline & & Ryazanian \\
\hline \multirow{11}{*}{ 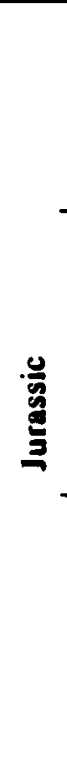 } & \multirow{3}{*}{$\begin{array}{l}\text { ఏ } \\
\text { 옹 }\end{array}$} & Volgian \\
\hline & & Kimmeridgian \\
\hline & & Oxfordian \\
\hline & \multirow{4}{*}{$\frac{0}{\bar{z}}$} & Callovian \\
\hline & & Bathonian \\
\hline & & Bajocian \\
\hline & & Aalenian \\
\hline & \multirow{4}{*}{$\begin{array}{l}5 \\
\vdots \\
3 \\
9\end{array}$} & Toarcian \\
\hline & & Pliensbachian \\
\hline & & Sinemurian \\
\hline & & Hettangian \\
\hline \multirow{6}{*}{$\begin{array}{l}\text { 号 } \\
\text { 总 } \\
\text { 量 }\end{array}$} & \multirow{3}{*}{$\begin{array}{l}\text { 일 } \\
\frac{2}{2}\end{array}$} & Rhaetian \\
\hline & & Norian \\
\hline & & Carnian \\
\hline & \multirow{2}{*}{$\frac{\tilde{y}}{\bar{z}}$} & Ladinian \\
\hline & & Anisian \\
\hline & \multirow[t]{2}{*}{$\begin{array}{l}\overline{\mathbf{J}} \\
\mathbf{z} \\
\end{array}$} & Scythian \\
\hline & & Permian \\
\hline
\end{tabular}

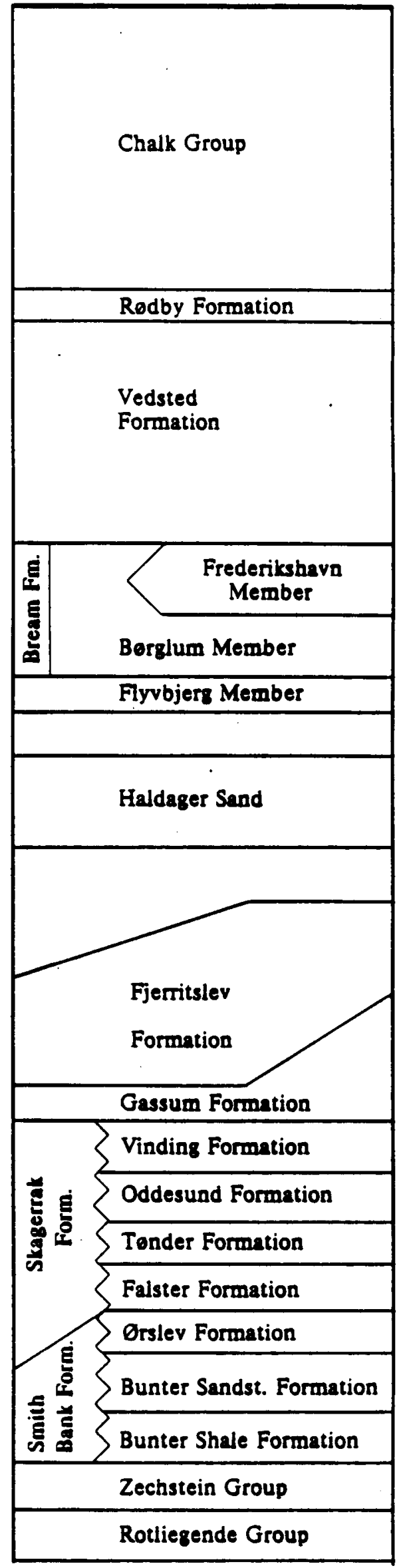


Only cuttings were available from the Hyllebjerg 1 well; Samples were collected at approximately $60^{\circ}$ intervals throughout the Mesozoic sequence.

Fig. 2 Generalized Iithostratigraphy of the Danish Subbasin. (Michelsen ?987). 
In this study, the source rock potential of the Mesozoic sediments was evaluated by different optical and chemical methods. Coal petrographic optical methods (e.g. reflectance measurements on huminite/vitrinite and spectral fluorescence measurements on extracted bitumens) were used for estimating the maturity of the sediments. Normal reflected light observations combined with fluorescence light techniques, were also used to provide information on the composition (type) of organic matter present. These optical methods were also used to assess the degree of reworking of the organic matter and the presence of cavings or other contaminants.

Combustion in an induction furnace was used to estimate the amount of organic matter. The maturity and type of organic matter was evaluated by several chemical parameters obtained from various analyses of the bitumen fraction (e.g. extraction data, gas chromatographic analyses (GC) and combined gas chromatographic - mass spectrometric analyses (GC-MS )) .

Details of the analytical methods and instruments used are given in the appendix. 
14 
Amount of organic matter

Total organic carbon (TOC) values are listed in table 1 (together with the dominant cuttings Iithology) and shown in fig. 3. The relative amount of organic matter in the polished specimens was also assessed under the microscope during description of the organic matter composition (table 7).

Most of the samples were claystones/shales or coarser grained silts/sandstones; a few carbonaceous cuttings were included in the uppermost and lowermost samples.

The total organic carbon values varied from 0.19 to $2.71 \%$. wt for the various samples analysed with the lower values in the more sandy and carbonaceous samples. Most samples contained about 1\% wt TOC, which is the average value for a "normal" shale (Gehmann 1962, Hunt 1972').

The uppermost 3 samples of the Vedsted Formation had rather low organic contents with values of about $0.5 \%$ wt TOC, in part caused by considerable contamination, especialIy by chalk cavings, especially in 910A and 913A. Some low values are also seen in samples from the Gassum, Vinding and oddesund Formations with a slightly decreasing trend in TOC-values downwards. Mean values for hydrocarbon source rocks (shales/claystones) are in the range of $1.5-2.5 \%$ wt TOC (Tissot \& Welte 1984). In the North Sea the range is 1-8\% wt TOC (Thomsen et al. 1987).

Only few samples fall within the typical source rock range, as TOC-values > $1.5 \%$ wt are only recorded from a few upper Fjerritslev Formation samples and one anomalously organic-rich sample from the Vedsted Formation. While a few coaly particles are present in some of the sandy samples from the Haldager and Gassum Formations, no pronounced high TOC-values are recorded here. 
HYLLEBJERG 1

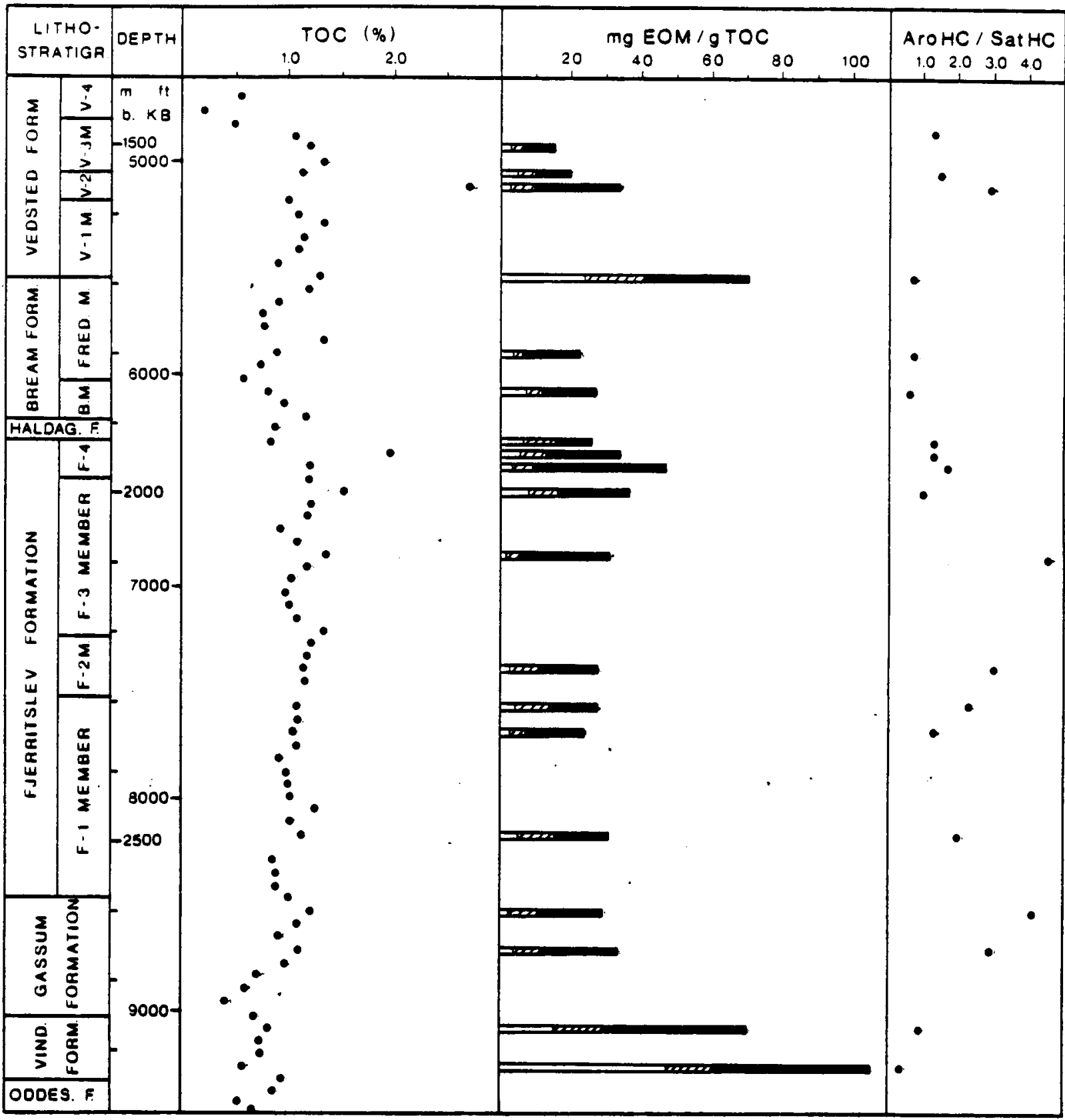

Sat HC Aro HC Res + Ason

Sat HC. Saturated Hydrocarbons

Aro HC. Aromalic Hydrocarbons

Res - Resins

Asoh. Asphaitenes

Fig. 3 Total organic carbon (TOC) and extractability values ( $E O M$ = extractable organic matter) 
As minimum values are conventionally set at $0.5 \%$ wt TOC for shales and $0.3 \%$ wt TOC for carbonates to be potential source rocks (Tissot \& Welte 1984), most of the samples meet this demand, but in some of the samples from the deeper part of this well the lower organic content may be critical for the hydrocarbon potential. However the hydrocarbon potential is only affected by the percentage of carbon which is hydroçarbon prone.

If the lower limit is set at $1 \%$ and $0.5 \%$ wt TOC for shales and carbonates respectively, as is done in many laboratories (Tissot \& Welte 1984), the amount of organic matter seems generally too low in the sediments from the Vinding and Oddesund Formations for them to be potential source rocks, whilst in most of the other sediments investigated, TOC-values are close to this critical value.

Thus, on the basis of TOC-values, the hydrocarbon potential must be regarded as relatively low for most of the sediments in the investigated sequence, with the possible exception of the samples noted above.

\section{Composition of the organic matter}

Description:

Coal petrographic descriptions of the organic matter and evaluations of its composition are given in table 7 . A short summary of the sediments from the different Formations is given below:

The Vedsted Formation is characterized by marine claystone and siltstone. The organic matter is generally dominated by pseudovitrinite with slightly increasing contents of liptinite (alginite) with depth. The uppermost samples 909A-913A are dominated by pseudovitrinite, often showing evidence of reworking and/or oxidation (oxidation rims and shrinkage- 
cracks); only a few wisps of huminite/vitrinite and liptinite fragments are present. In $910 \mathrm{~A}$ and $911 \mathrm{~A}$ the composition tends to be masked by contamination. In $912 \mathrm{~A}$ and $913 \mathrm{~A}$, some more coarse-grained huminite/vitrinites are present. Samples $\underline{914 \mathrm{~A}}$ and $915 \mathrm{~A}$ are still dominated by pseudovitrinite, but with an increased liptinite content (especially in 915A) and only a few small huminite/vitrinite fragments. Among the alginites some dinoflagellates can be identified. Sample $916 \mathrm{~A}$ is very different from the other material examined from this formation. It is characterized by a very bigh and very fine grained organic content, mostly composed of liptinite, especially bituminite (associated with many small pyrite framboids) and a few alginites (dinoflagellates). The huminite/vitrinite grains are small and angular. There is a relatively high content of. fine grained inertinite. The following samples $917 \mathrm{~A}-922 \mathrm{~A}$ resemble $914 \mathrm{~A}$ and $915 \mathrm{~A}$.

The Bream Formation is characterized by low energy sediments (Børglum Member) overlain by high energy near-shore sediments (Erederikshavn Member). The organic matter is composed of about equal amounts of liptinite (most alginite) and pseudovitrinite, with only very low huminite/vitrinite contents. Samples $923 \mathrm{~A}-926 \mathrm{~A}$ have varying organic contents with the somewhat higher organic contents caused mainly by fine grained liptodetrinites and some alginites (dinoflagellates). In the samples $927 \mathrm{~A}$ and $928 \mathrm{~A}$, the lipitinite content is slightly increased and large alginite fragments (dinoflagellates) are dominant in 929A, especially in the coarse grained cuttings. Thereafter the grain size and organic content decrease with depth. In $230 \mathrm{~A}-934 \mathrm{~A}$ the Iiptinite is mostly fine grains, and more inertinite is observed.

The Haldager Formation is characterized by fluvial-deltaic sediments (Haldager Sand Member) overlain by marine heterolithic shallow water sediments (Flyvbjerg Member). The organic matter is composed of roughly equal amounts of liptinite and pseudovitrinite. Sample $935 \mathrm{~A}$ resembles the overlying material as fine grained liptinites are prevalent, 
but the identifiable liptinites show a somewhat more terrestrial composition (sporinite, bituminite, ?cutinite). Sample $936 \mathrm{~A}$ (transition to the Fjerritslev Formation) is similar to $935 \mathrm{~A}$, but also contains some small angular huminite/ vitrinite particles (a few of them are very large).

The Fjerritslev Formation is divided into four members characterized by marine claystone and shale, representing changing energy environments. The organic matter is dominated by fine grained liptinite (most bituminite and liptodetrinites, some alginite and sporinite) in the upper section (F-4 and upper part of F-3 Members) but the content decreases with depth. However the pseudovitrinite and huminite/vitrinite proportions increase with depth, with pseudovitrinite dominating the lower part of the section (especially in the F-1 Member). In the lowermost part of the Formation, the organic matter becomes coarser, indicating the transition to the Gassum Formation.

The organic content is relatively high in the uppermost of the samples $937 \mathrm{~A}-947 \mathrm{~A}$ and is dominated by liptinite. In $937 \mathrm{~A}$ pseudovitrinite and huminite/vitrinite particles still make up a considerable proportion of the organie matter, but their amount clearly decreases in the following samples as the quantity of liptinite increases. The liptinite is very fine grained and composed of many bituminite streaks (with dull orange-brown pluorescence and small greenish fluorescing ?algal-inclusions) associated with small pyrite framboids, some sporinite and some large alginites (Tasmanites) and fragments of alginite. In some of the samples (941-944A) most of the organic matter is composed of bituminite. Slightly varying amounts of alginites are present in all samples. Tasmanites have been observed only in samples $937 \mathrm{~A}$, 938A, 940A and 945A. The contents of pseudovitrinite and huminite/vitrinite are again enhanced in $946 \mathrm{~A}$ and $947 \mathrm{~A}$ which contain more coarse grained organic matter. Sample 948A-950A are rich in pseudovitrinite with some coarse grained huminite/vitrinite (with cellular structure) whilst the liptinite content is low. The liptinite generally fluoresces dull orange, suggesting some reworking. 
In samples 951A-967A pseudovitrinite is generally dominant with less huminite/vitrinite and varying, but small, amounts of liptinite. In $952 \mathrm{~A}-956 \mathrm{~A}$ almost no liptinite (mostly small unidentifiable liptodetrinites) is observed. In some of the samples (957A, 958A) a few Tasmanites are present, probably in ?cavings. True huminite/vitrinite grains are usually sparse, but are slightly more abundant (coarse grained with recognizable cellular structure) in $954 \mathrm{~A}-956 \mathrm{~A}$. In $957 \mathrm{~A}$ and deeper sample the pseudovitrinite proportion clearly dominates with many grains showing evidence of reworking and/or oxidation (oxidation rims and shrinkage cracks). These samples are also characterized by some small splinters of inertinite, some containing sclerotinites (especially 963A-966A).

In $968 \mathrm{~A}$ and $969 \mathrm{~A}$ highly mixed cuttings are observed with compositions like the samples above and below. In 970A-972A (the latter sample belongs to the Gassum Formation) a coarsening of the organic particles composed of about equal amounts of pseudovitrinite and huminite/vitrinite is seen (angular and gnarled) while the liptinite content is very low.

The Gassum Formation is characterized by deltaic - shallow water littoral sand- and siltstones interbedded with claystones. The content of the organic matter pluctuates with coarse-grained pseudovitrinite and huminite/vitrinite particles, low liptinite (terrestrial marker) contents and a few genuine coal grains. There is a decreasing organic content downwards.

Samples 973A-977A are somewhat variable. The upper ones are not essentially different from the overlying samples, but a few genuine coal grains (composed of desmocolinite, corpocollinite, sporinite - 973A) are observed and a low, but more varied content, of terrestrial liptinites, mostly sporinite and bituminite (in some samples (973A, 976A) resinite and cutinite are also observed). In $975 \mathrm{~A}$ many carbonaceous cuttings are present with angular huminitel vitrinite and pseudovitrinite particles present. In 
$978 \mathrm{~A}$ and $979 \mathrm{~A}$ highly mixed lithologies with some coarse grained cuttings of very low organic content are observed. A low content of organic matter is also observed in $980 \mathrm{~A}$ and $981 \mathrm{~A}$ consisting mainly of pseudovitrinite and few angular huminitel vitrinite particles. There is almost no liptinite present.

The Vinding Formation is characterized by shallow brackishmarine deposits of claystone and limestone. The organic matter is characterized by a generaliy low organic content, mostly of liptinite, liptodetrinites and alginite of Botryococcus type). Unfortunately only a few samples were available for analysis.

In $982 \mathrm{~A}$ some small huminite/vitrinite and pseudovitrinite grains are seen together with some liptinite (liptodetrinites and sporinite). In $984 \mathrm{~A}$ and $985 \mathrm{~A}$ the low organic content is largely dominated by liptinite; in $984 \mathrm{~A}$ mostly as liptodetrinites and in $985 \mathrm{~A}$ as alginite of Botryococcus-type. Botryococcus (bright yellow fluorescence) are especially numerous in a few cuttings, whilst in others the Botryococcus algae show yellow-orange fluorescence and their tousled apperance may be due to reworking and/or oxidation.

The Oddesund Formation is characterized by continental and brackish water claystones and siltstones with carbonates and evaporites. There is only a very low organic content. The general composition in 987A-989A is difficult to estimate because of the very low content and finegrained nature of the organic matter.

Hydrocarbon potential:

The composition of the organic matter is affected by the depositional environment of the sediments. Land-derived organic matter is generally found in near-shore areas, whilst phytoplankton represent the main source of organic matter in marine sediments, as noted by many authors (e.8. Dow 1977b, Brooks 1981, Huc 1980, Tissot \& Welte 1984, 
Glennie 1984). This is also valid for the composition of the organic matter encountered in the Danish Subbasin (Lindgreen \& Thomsen 1982, Schmidt 1985) though a relatively high input of terrestrial material, with an obvious reworked appearance, is present in many of the marine sediments of the Mesozoic. This is especially seen in the Vedsted Formation (except for the sample $916 \mathrm{~A}$ ) and the deeper part of the Fjerritslev Formation (F-1, F-2 and deeper F-3 Members). Here the organic matter is dominated by extensively. reworked and oxidized pseudovitrinite with only a minor contribution of liptinite. As most of the pseudovitrinite may be thermalIy inert, the hydrocarbon potential is considered to be low for these sediments.

This may to some degree also be true for the Bream Formation sediments, but the somewhat higher content of liptinites (the small liptodetrinites may be derived from phytoplankton) may increase the hydrocarbon potential as algal material normally has a good potential for oil. The Bream Formation sediments are equivalent to the "black shales" (viery organic rich, composed of algal and bituminous organic material) of the Kimmeridge Clay Formation/ Børglum Member in the Graben structures of the North Sea, where they provide the dominant source rock for oil in the central and northern North Sea (Barnard \& Cooper 1981, Cornford 1984). However, in the equivalent sediments in this well no comparably favourable organic matter compositions were detected.

Too little information is avallable from the Haldager Formation to provide a general characterisation of 1 ts hydrocarbon potential as only one sample without pronounced organic content was available.

The sediments of the upper part of the Fjerritslev Formation sediments (F-4, upper F-3 Member) with a high organic content dominated by bituminite and alginite have one of the most promising source rock potentials of the sediments investigated. Generally, bituminite (often considered to be bacterial lipids and decomposition products of algae and faunal plankton (Teichmüller 1982)) and alginite are consi- 
dered to be good precursors for oil. Bituminite, together with alginite, are the predominant macerals of oil source rocks and oil shales (Tissot \& Welte 1984, Hutton et al. 1980). As the sediments investigated locally show these characteristics, they are considered to have a good oil potential (unless the bituminite is composed of degraded humic material of terrigeneous origin which may lower the potential). This type of sediment thus indicates reducing depositional enviroments with good preservation conditions for the organic matter. This is in good agreement with the assumed depositional environment of the upper F-3 and F-4 Member sediments in deep water and lagoonal environments with strongly reducing conditions close to the bottom (Michelsen 1978).

Sample $916 \mathrm{~A}$ from the Vedsted Formation is of the same sediment type (high organic content of bituminite with some alginite in association with a very high content of pyrite framboids). Thus a change during the lower Cretaceous from more or less "normal" marine coditions to more anoxic en- vironments and the reverse seems tö be indicated. The common occurrence of framboidal pyrite seems to attest to the action of sulphate reducing bacteria during this event.

In the Gassum Formation sediments, organic matter is characterized by a higher input of terrestrial matter with only minor signs of reworking. Also the liptinite composition shows a somewhat more terrestrial imprint to the organic matter. The humic composition indicates a major potential for gas whilst the liptinites present may contribute with oil or condensate of characteristic type if a sufficient maturity is reached.

Sediments of the Vinding Formation have a good potential for oil in some horizons as the organic matter is mainly composed of algal material of Botryococcus-type. But as the amount is estimated to be low, the hydrocarbon potential will be reduced.

The organic matter in sediments representing part of the Oddesund Formation reveals no clear evidence of its hydro- 
carbon potential, but it is generally assumed to be low because of the low content of organic matter.

\section{Vitrinite reflectance measurements}

The results of the vitrinite reflectance measurements are presented in Table 2 and the reflectance trend for the well is illustrated in Fig. 4.

The measurements have generally been performed on very small wisps and splinters of huminite/vitrinite. Many of the samples contain low reflecting bituminous and "A"-types (Stach et al. 1975) unsultable for rank determination and making the analysis problematic (see appendix).

Sample 973A from the Gassum Formation is used as a marker horizon as it contains a few coal particles which unambigously define the maturity/rank of the sediment. In these coal particles desmocolinite and corpocollinite can be recognized and are used to estimate the lower and upper limit respectively of the realistic reflectance range. These results, together with measurements of the dispersed huminitel vitrinite in the same sample are shown in $11 \mathrm{~g} .5$. The range of the dispersed vitrinite particles is sightly broader than for the measurements on the coal particles.

Larger fragments of angular huminite/vitrinite are present in samples $936 \mathrm{~A}$ and $975 \mathrm{~A}$, Indicating autochtonous material.

As the reflectance measurements on these particles showed a unimodal distribution with relatively little scattering of the values, and many measurements were possible, these samples are also used as marker horizons. The reflectance range used for these samples proved to be in good agreement with the marker horizon values.

During the analyses much attention was paid to the lithology of the cuttings so as to avold measurements on cavings or mud additives. The last casing was set in Cretaceous 
HYLLEBJERG 1

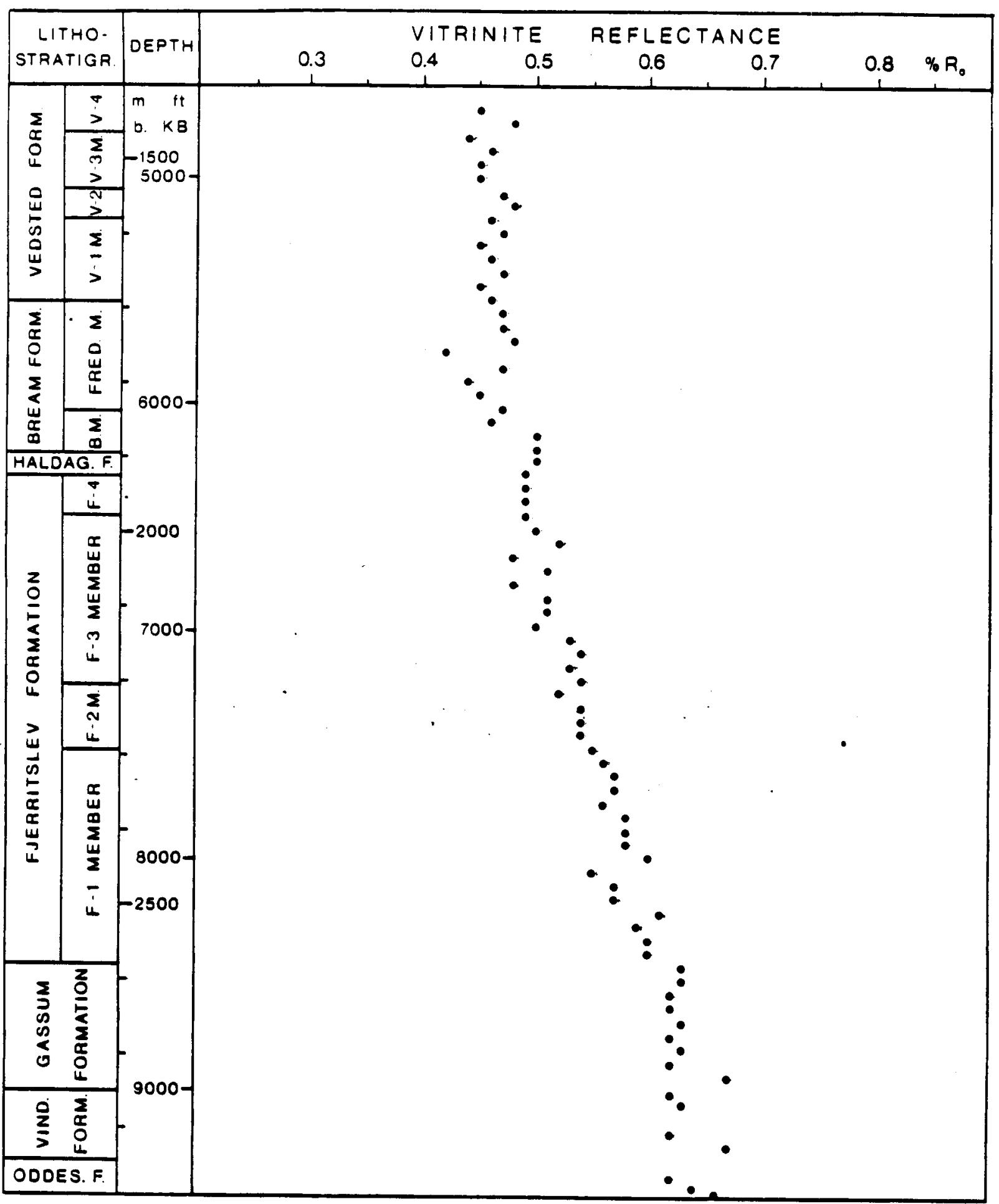

Fig. 4 Vitrinite reflectance measurements. 
sediments at 3495 ft.b.KB (Well Data Summary Sheets 1981). The analyses were performed on the samples from the top downwards: Cuttings in samples with different lithology from the overlying one were chosen for measurements if they were considered to represent meaningful lithological change in the sequence, provided that the reflectance range is not significantly lower than in the previous samples. Since the investigated intervals often have almost identical lithologies, the possibility that material from overlying lower rank intervals have been included in the measurements cannot always be excluded. A sequence with rapidly changing lithology with low organic contents of often oxidized and/or reworked material and sometimes large amounts of contaminants (as is seen particularly in the deepest part of the well) is difficult to measure and gives less reliable results than the rest of the well.

All mean $R_{0}$-values are plotted against depth to illustrate the reflectance trend ( 18.4$)$.

The maturity of the organic matter is dependent on timetemperature relationships. Maturation increases approximately Iinearly with time and exponentially with temperature and a semi-logaritmic plot of huminite/vitrinite values versus depth in a continously subsiding basin will show a straigth line i.e. the maturation profile, assuming a constant geothermal gradient (Dow 1977a).

Consequently, Least square regression analysis has been undertaken. Using this calculation method a very high degree of correlation is achieved $(r=0.96)$ and the following $R$-values are estimated: surface 0.29 \% $R, 1000 \mathrm{~m}: 0.38$ \% $R$, $2000 \mathrm{m:} 0.51 \% \mathrm{R}_{0}, 3000 \mathrm{~m}: 0.68 \mathrm{kR}$ and $4000 \mathrm{~m}: 0.90 \mathrm{o} \mathrm{R}_{0}$ which establishes the reflectance trend.

Reflectance measurements on corresponding Mesozoic sediments from wells outside the basinal depocenter of the Danish Subbasin show a steeper average maturation profile (less maturation per unit depth) than the Hyllebjerg 1 profile (see 1 ig.6). This seems to be due to the sligthly higher geothermal gradient in the central part of the basin 


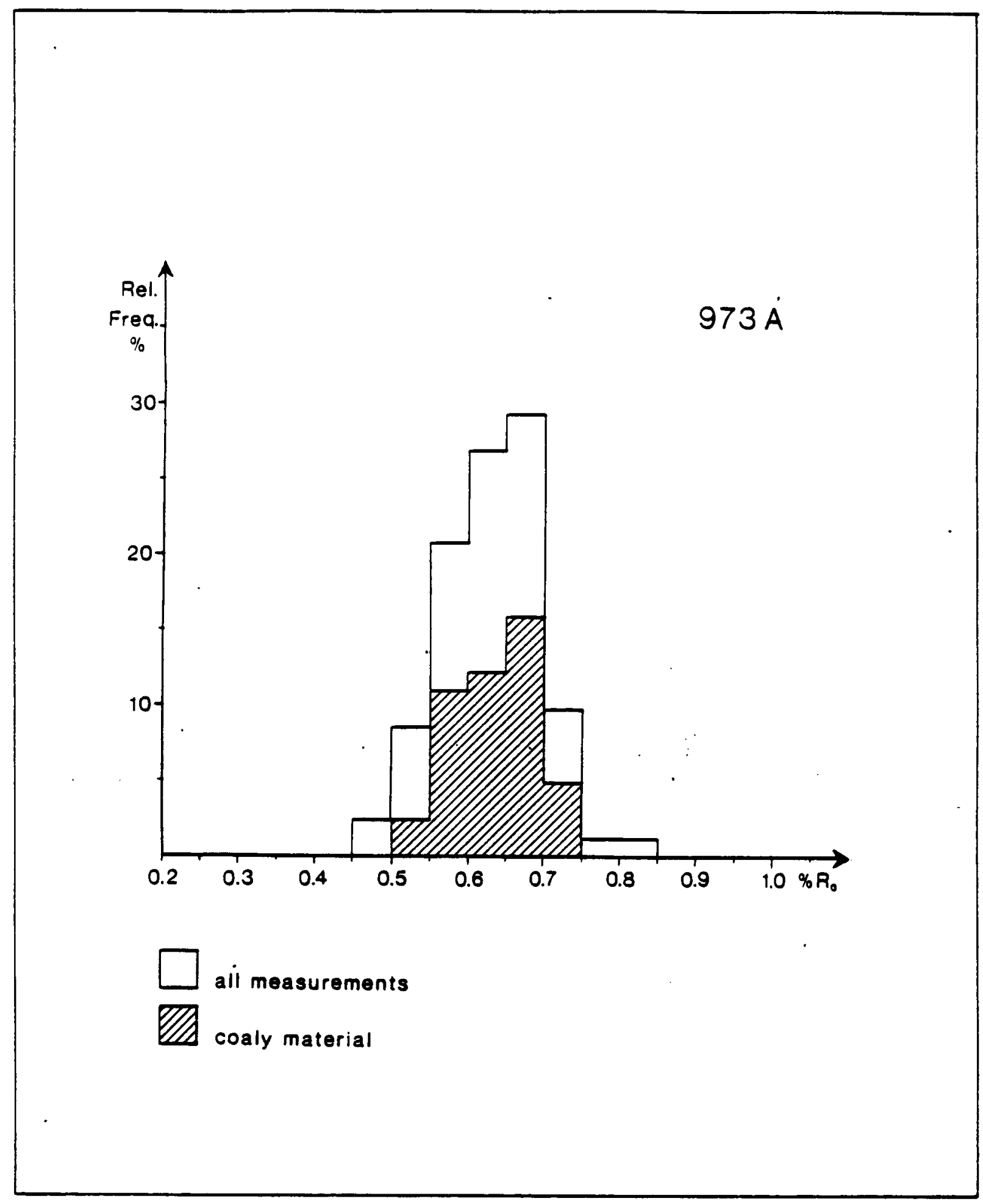

Fig. 5 Reflectogram of the marker horizon $973 \mathrm{~A}$, showing all reflectance measurements with measurements on the coaly material indicated (= shaded area). $\mathrm{R}_{0}=$ $0.63 \%$. 
(Hyllebjerg 1: $28^{\circ} \mathrm{C} / \mathrm{km}$ uncorrected) compared with the more marginal areas towards the Fennoscandian Border zone and above the Ringkøbing-Fyn-High where it is estimated to average $23.5^{\circ} \mathrm{C} / \mathrm{km}$ uncorrected (Madsen 1975, 1978, Balling 1978, 1979, Michelsen et al. 1981). In the central part of the basin also a higher heat flow has been calculated (Balling 1979).

Mature sediments may thus be expected at shallower depths in Hyllebjerg 1 than in the other investigated wells outside the basinal depocenter.

The $R_{0}$-values 1 ie between approximately 0.40 and $0.65 \% R$ and show a clear depth related trend from immature to slightly matured sediments, reaching $0.65 \mathrm{KR}$ at the terminal depth of the well (equivalent to the high volatile bituminous $B / C$ coal rank). Conventionally $0.55 \% R$ is used as a threshold value for the onset of oil generation (world - wide accepted "average"), but different maturity levels exist for different types of organic matter with varying rates of transformation with increasing temperature (IIssot \& Welte 1984, Vandenbrouke 1980) (see fig. A-1). A maturation level of $0.50 \mathrm{RR}$ is reached at a depth of approximately $6400^{\circ}$, i.e. at the top of the Fjerritslev Formation. Thus the sediments from the upper part of the well, including Vedsted, Bream and Haldager Formation deposits, are obviously immature as the reflectance trend shows values below $0.50 \mathrm{gR}$. The sediments beneath might have attained maturity but no commerclal hydrocarbons have been encountered in the well. The exact threshold value for onset of the oil generation zone, i.e. the top of the socalled "oll window" has not been estimated yet for this on-shore area.

However, according to Cornford (1984) the threshold value in terms of vitrinite reflectance is set near $0,60 \% \mathrm{R}$ for the North Sea area. With $0,60 \% \mathrm{R}$ taken as a threshold value (also used by Thomsen et al 1987) mature sediments might be reached near the top of the Gassum Formation sediments at about $8500^{\circ}$ depth. By extrapolation of the reflectance trend the lower limit of $1.3 \mathrm{kR}$ ( $1 . e$. the base of this "ofl 
window") can be predicted at approximately $17.400^{\circ}$. depth, presumably in Triassic redbeds.

Thus the "oil window" is expected from $8500^{\circ}-17.400^{\circ}$ (2600m

- $5300 \mathrm{~m}$ ) at the location of Hyllebjers 1 , which is a narrower interval occuring at a shallower depth than the 2700-6000 m estimated for the marginal area of the Danish Subbasin (Lindgreen \& Thomsen 1982). Whilst sufficient maturity seems to be reached in the deeper part of the well, only small traces of non migrated hydrocarbons can be detected. The possible reasons for this will be discussed in the final section.

\section{Spectral fluorescence measurements}

The fluorescence data from measurements on extracted bitumens are listed in table 3. The calculated trichromatic coordinates $x, y$ from the measured spectral curves are plotted graphically in a two-dimensional diagram (DIN 6164 for the illumination $D 65$, fig. 7) where the maturity can be shown. The straight lines which divide the diagram into 24 parts indicate the shade of colour, while the curved lines characterize the degree of colour saturation.

It is shown that the shade of fluorescence colour of extracts from coals and different source rocks changes with increasing maturity in a clock-wise direction in the diagram (blue line no. 16-19) at the coalification stage of peat, through green (20-24) and yellow (1) to orange (4-6) at the highly coalified stage of anthracite and even higher values) simultaneously with an increase in saturation (Hagemann \& Hollerbach 1981a).

According to recent investigations (Hagemann, pers. comm.) the shade of colour can be correlated with huminite/vitrinite reflectance although the changes in fluorescence properties of the extracts are discontinous, while the reflectance behaviour of the huminite/vitrinite particles indicates a gradual continuous changes. The colour shade between 
MATURATION PROFILE

-Hyllebjerg 1

- Danish Subbasin (marginal)

E

0

Fig. 6 (Data for marginal Danish Subbasin from Lindgreen \& Thomsen (1982)). 
lines 21 and 24.5 corresponds to a huminitel vitrinite reflectance of approximately $0.25-0.50 \% R$, line 24.5 with approximately 0.50-0.75 \% $R$, lines $1-3$ with $0.75-1.15$ and lines 3-5.5 with approximately 1.20-1.50\% $R_{0}$. The dividing Iine between immature and mature sediments is drawn at about the shade of colour between lines 24.5 and 1 (Hagemann, pers. comm.).

The plotted chromaticity values in fig. 7 shows the samples to range from almost unaffected to mature organic matter. The results are generally in reasonable accordance with those of Hagemann as most values plot between the shade lines 24 and 1 , indicating relectance values of about $0,45-0,75 \% R_{0}$. An increasing maturity is seen in a clockwise direction starting from samples af the Vedsted Formation to samples of the Fjerritslev, Gassum and Vinding Formation, together with an increase in saturation from close to curve no. 2 to curve no. 5 .

Some lower and higher shade values are observed which do not correspond to the reflectance measurements. The lower shade values are from the Vedsted and Bream Formation samples which consist of unconsolidated material.

The calculated two shade values about line 22 (samples $916 \mathrm{~A}$ and 923A) suggest unrealisticly immature, almost recent sediments (rank equivalent to peat - soft brown coal) but the gas chromatograms show severely biodegraded and possibly contaminated samples respectively. The reflectance measurements show higher maturity with values about $0.45-0.50$ \% $\mathrm{R}$.

Maturity estimations from chromaticity values of the other samples (913A-932A) of the Vedsted and Bream Formations (between the shade lines 23-24.5) must also be done with some reservation as the extracts from these samples often seem to be more or less contaminated, and only very small amounts were available.

The shade values. obtained from the Fjerritslev, Gassum and Vinding Formations are rather similar, mostly between shade Iines 24.5 and 1 , which indicates the transition zone from immature to mature sediments. A few of the samples from the 


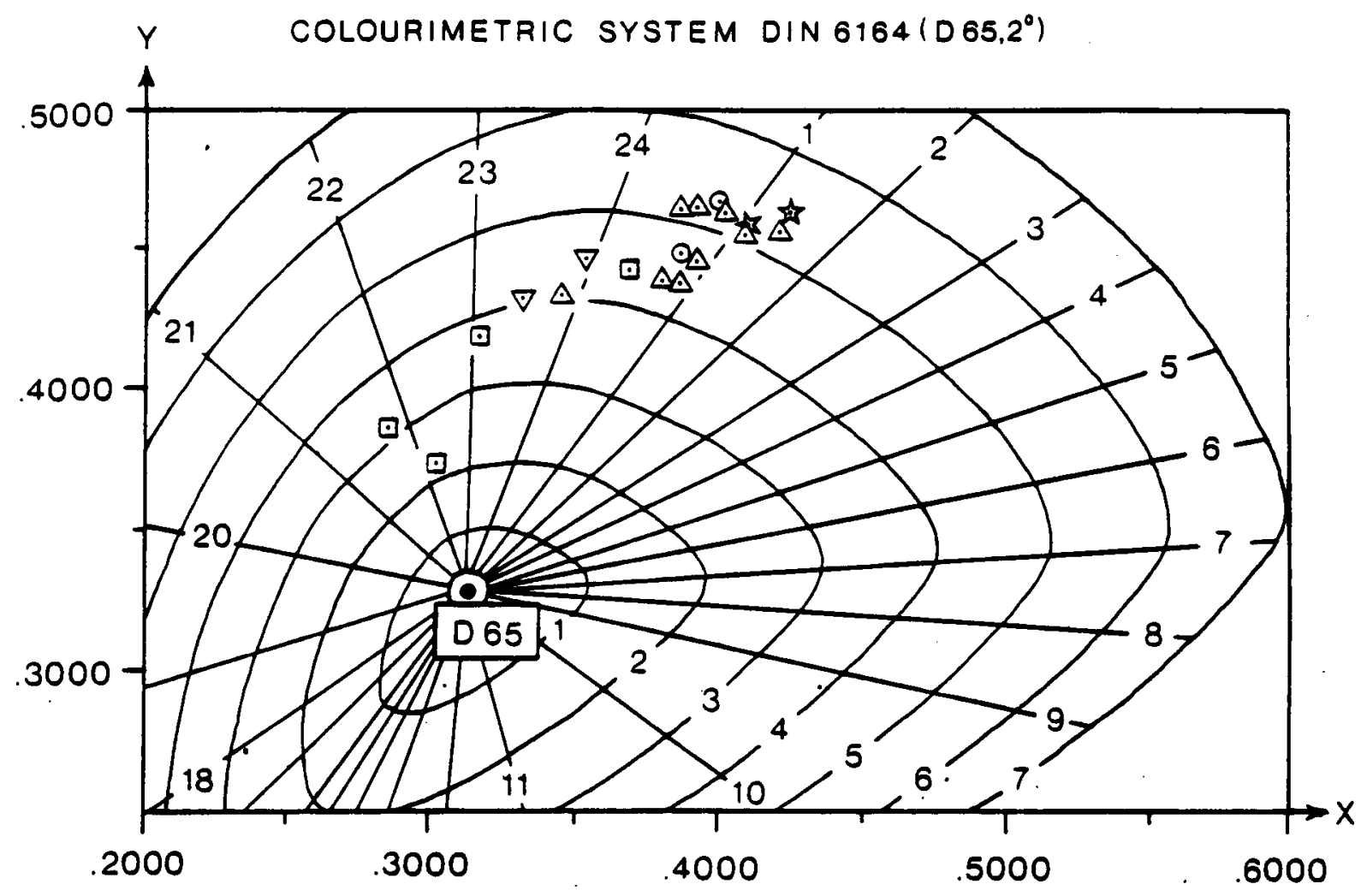

- VEDSTED FORMATION

$\nabla$ BREAM FORMATION

$\triangle$ FJERRITSLEV FORMATION

* GASSUM FORMATION

- VINDING FORMATION

Fig. 7 Chromaticity diagram DIN 6164 showing shade (straight lines 1-24) and saturation of colour (curved lines 1-7) of extracts from different cutting samples. 
Fjerritslev and Gassum Formations (945A, 954A, 973A and 976A) clearly lie in the "oil window" (boundaries approximately at shade line 24.5-1 to 4) with their shade values higher than 1 . On the other hand the fluorescence analysis indicates that the two lowermost samples from the Vinding Formation (982A, 985A) do not reach this maturity. This clearly contradicts the reflectance measurements and extractability results which both show the highest maturity for the Vinding Formation samples. This is also shown by linear regression analysis. Calculations on $Q$-values from the spectral curves and $\lambda$ max values with corresponding $R_{0}$-values show relatively low correlations $(r=0.59$ and 0.58 respectively; $916 \mathrm{~A}$ and $923 \mathrm{~A}$ omitted). (See fig. 8). In the literature (Ottenjann et al. 1974, Teichmiller \& Ottenjann 1977 , Teichmuller \& Wolf 1977, Teichmüller 1979, Ottenjann 1980, Teichmüller \& Durand 1983) it is shown that different liptinite macerals have originally different fluorescence colours and distinctively changing spectral fluorescence properties with increasing maturation. Alginites show more shorter wavelength iluorescence colours with higher intensities than most other liptinites (i.e. sporinite, cutinite and bituminite) at equal maturity.

Maturation is characterized by a decrease of fluorescence intensity, and a shift in eluorescence colour to the red part of the spectrum. Spectral composition and intensity vary for the different liptinite macerals, as well as for the different maturity levels.

In this study samples $945 \mathrm{~A}, 954 \mathrm{~A}, 973 \mathrm{~A}$ and $976 \mathrm{~A}$ with the highest shade values $>1$ and thus a higher proportion of the longer wave length orange red light in the spectra (i.e. high Q-values), also show the highest aromatic hydrocarbons/saturated hydrocarbons ratio > 2.5 (see table 4 and (ig. 3).

A high aromatic hydrocarbon/saturated hydrocarbon ratio may indicate terrestrial origin or a high terrestrial proportion of organic matter with fluorescence parameters which normally indicate mature material and thus can resemble increased maturity. In contradiction to this, aromatic 

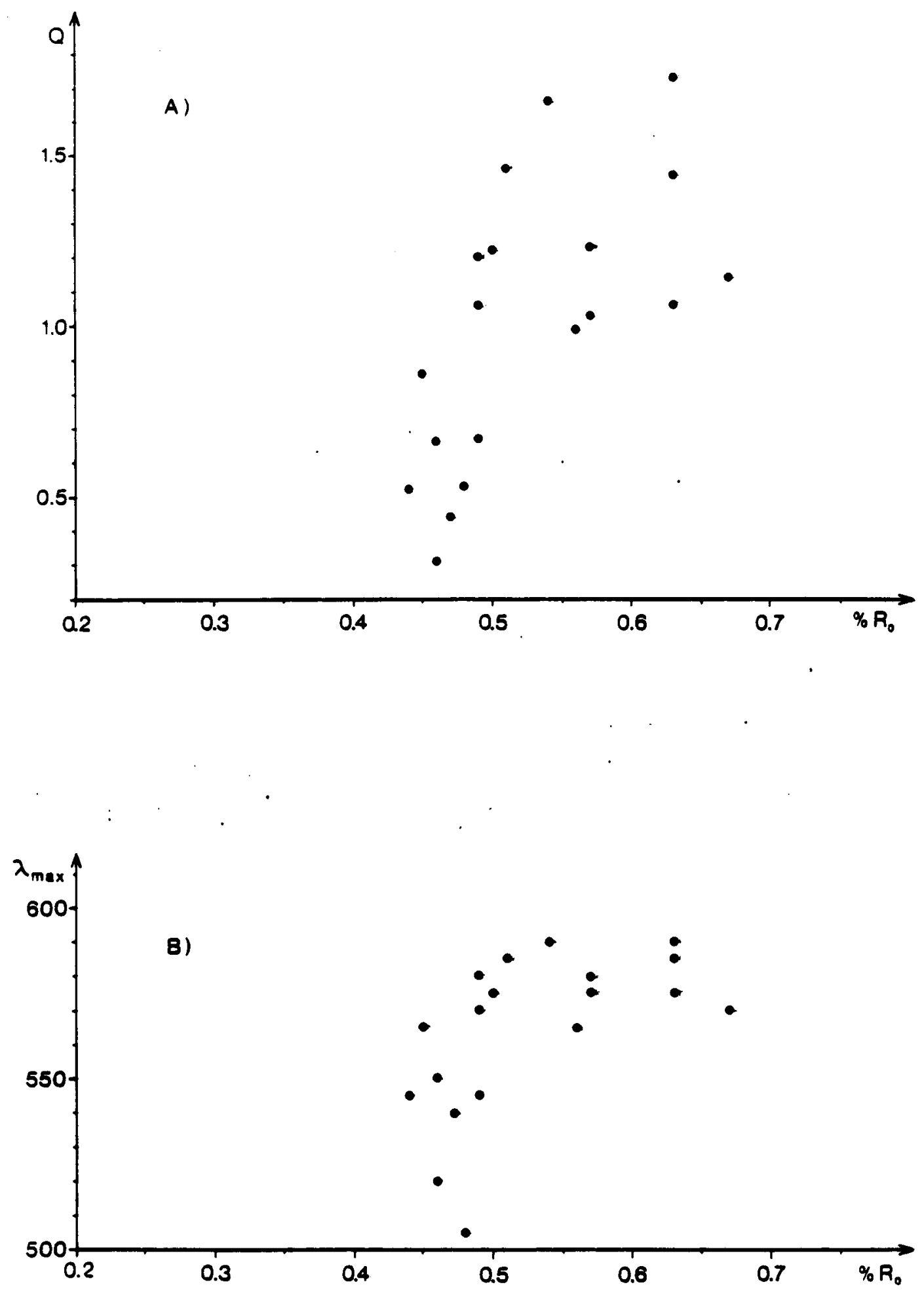

Fig. 8 Correlation tests of Q-values (=relative intensity at $650 \mathrm{~nm} /$ relative intensity at $500 \mathrm{~nm}$ ) and $\lambda_{\max }-$ values ( $=$ the position of the maximum wavelenght in nm) from the spectral eluorescence curves with the corresponding $\% \mathrm{R}_{0}$-values ( = vitrinite reflectance).
A) $r=0.59$
B) $r=0.58$ 
hydrocarbons/saturated hydrocarbons ratio < 1.0 are obtained from samples 929A, 932A, $982 \mathrm{~A}$ and $985 \mathrm{~A}$ with algal or marine phytoplankton dominated organic material, giving clearly lower fluorescence parameters. As lipophilic substances, such as the aromatic and heteroaromatic compounds, influence the spectral character of the fluorescing light, it is not surprising that the investigated samples with such varying extract composition show different spectral curves, giving a complex maturation picture, as is also seen for the different liptinite macerals.

The distribution of the fluorescence data in the chromaticity diagram, and the reasonable correlations with the reflectance values, seem to reflect dependence on the organic type which have different fluorescence properties. The latter are superimposed on, and to some extent mask, the maturation effect.

This is clearly in opposition to Hagemann \& Hollerbach (1980, 1981a, 1981b) who claimed that the extract composition was independent of the kerogen type. However, it must be pointed out that this method has not previously been tested on cutting material from a basin with often shifting lithologies and thus varying organic compositions (kerogen types), and more data are needed. However, it does seem possible to use this new analytical method for a rough ma+..-ity estimation.

Extractable organic matter (EOM) and chromatographic separation

Extraction methods are described in the appendix

The amounts of extractable organic matter (EOM) and the composition of the chromatographic fractions are given in table 4. The EOM and the hydrocarbon content (saturated plus aromatic hydrocarbons) are normalized to total organic carbon content (TOC) to minimize random spread of extraction 
results due to the different content of organic matter. The results are shown in fig. 3, where the composition is also indicated.

As relatively minor amounts of sediment were available, only small extracts were obtained (between 8 and $54 \mathrm{mg}$ ). As part of this was used for fluorescence measurements very little was left for the chromatographic separation. Evaluation of the results must therefore be done with care as some scatter is to be expected.

The EOM results how increasing extractabilities and hydrocarbon ratios downwards, indicating increased maturity.

Most of the (upper) samples have ratios between 20-50 mg EOM/g TOC with the lowest ratios somewhat below $20 \mathrm{mg} E O M / g$ TOC form the uppermost samples. The same is true for the hydrocarbon content (mg HC/g TOC) as most samples generally have ratios < $10 \mathrm{mg} \mathrm{HC} / \mathrm{g}$ TOC (especially in the uppermost samples). or slightly above. This seems to indicate immature or Plushed sediments as in recent (immature) sediments the extractability and hydrocarbon ratios are fairly low with hydrocarbon contents generally $>10 \mathrm{mg} \mathrm{HC} / \mathrm{g}$ TOC (Tissot \& Welte 1984). In these samples, with approximately equal amounts of extracts, the varying composition of the extract may reflect different types of organic matter, as is seen under the microscope.

In samples $982 \mathrm{~A}$ and $985 \mathrm{~A}$ from the deepest part of the well there is a rapid increase in the EOM and the hydrocarbon content. This reflects increased maturity, though it may partly be caused by a change from terrestrial influenced to marine/brackish plant material, as is documented in the microscopic description of the organic matter. According to Tissot \& Welte (1984) the extractability is increased with greater maturity to a maximum of about $100-200 \mathrm{mg}$ EOM/g TOC with 70-150 mg HC/g TOC (actual amount dependent on the kerogen type) in the principal phase of oil formation, after which the extract values decrease as the principal phase is passed. Thus sample 985A, with a ratio above $100 \mathrm{mg}$ EOM/g TOC and $60 \mathrm{mg} \mathrm{HC} / \mathrm{g}$ TOC presumably represents a mature extract, although the hydrocarbon ratio obtained is lower than 
the former values. Mature sediments can therefore be found at approximately $9200^{\circ}$ depth in the Vinding Formation.

In the literature, extractability values of immature sediments with potential source rock characteristics are typically reported to be $30-40 \mathrm{mg}$ EOM/g TOC ( $T$ issot \& Welte 1984). According to this study, most sediments in the investigated sequence show relatively unfavourable source rock conditions. Only sediments from the F-4 and F-3 Member of the Fjerritslev Formation and possibly a few horizons from the Vedsted Formation, the F-1 Member of the Fjerritslev Formation and the Gassum Formation, lie within this range and may have a source rock potential for oil.

\section{Gas chromatography}

The gas chromatograms of the saturated fractions are shown in fig. 9. a-e, and the different ratios (pristane/n-C

alkane), phytane/n-C 18 alkane (phytane/n-C 18 ), pristane/phytane and Carbon Preference Index (CPI)) calculated from the peak areas are listed in table 5 and shown in fig. 10 .

The intensities in the chromatograms are not directly comparable since very small amounts of saturated hydrocarbons were available for analysis and sometimes the chromatograms have been recorded under high detector signal amplification; column bleeding can also be recognized in some of the chromatograms, especially for $929 \mathrm{~A}$ and $932 \mathrm{~A}$ and also slightly for some of the other samples.

In addition to this there are contamination and biodegradation problems.

Sample 923 is characterized by higher $\mathrm{n}-\mathrm{C}_{16}$ and $\mathrm{n}-\mathrm{C}_{18}$ peaks together with a large hump in the high molecular range. Because of the absence of the most n-alkanes it is considered to be biodegraded though there is a higher concentration of the $\mathrm{n}-\mathrm{C}_{16}$ and $\mathrm{n}-\mathrm{C}_{18}$ which cannot be explained. 
If it is contaminated the presence of contamination is not supported by the EOM/TOC value.

Contamination can be an uncertain factor, especially in the upper samples from the Vedsted and Bream Formation which consist of relatively unconsolidated material which is difficult to separate from the drilling mud by washing. Small amounts of contaminiation by drilling mud and/or mud additives can considerably affect and mask the results. However severe contamination from the mud itself is not likely as freshwater based mud with bentonite was used during the drilling, but the mud filtrate itself has not been analysed.

Sample $916 \mathrm{~A}$ on the other hand is anomalous in showing very high pristane and phytane peaks, giving high pristane/n-C, alkane and phytane/n-C 18 ratios compared with all the other samples. This may be caused by biodegradation (presumably due to meteoric water or storage of wet samples) which leads to loss of the n-alkane content, especially in the low molecular weight. range, while the isoprenoids are less affected and so pristane and phytane become relatively more abundant giving enlarged pristane/n-C 17 alkane and phytane/n-C 18 ratios (Deroo et al. 1974, Balley et al. 1973).

Since different lithologies and environments of deposition were investigated in this study, a variety of compositions of the organic matter can be expected to be indicated by the gas chromatograms.

Characterization:

A short summary of the main characteristics of the gas chromatograms is given below:

The Vedsted Formation is represented by samples 913A, 915A, $916 \mathrm{~A}$ and 923A. As $916 \mathrm{~A}$ and $923 \mathrm{~A}$ are blodegraded and/or contaminated. only samples $913 \mathrm{~A}$ and $915 \mathrm{~A}$ are reliable, as 

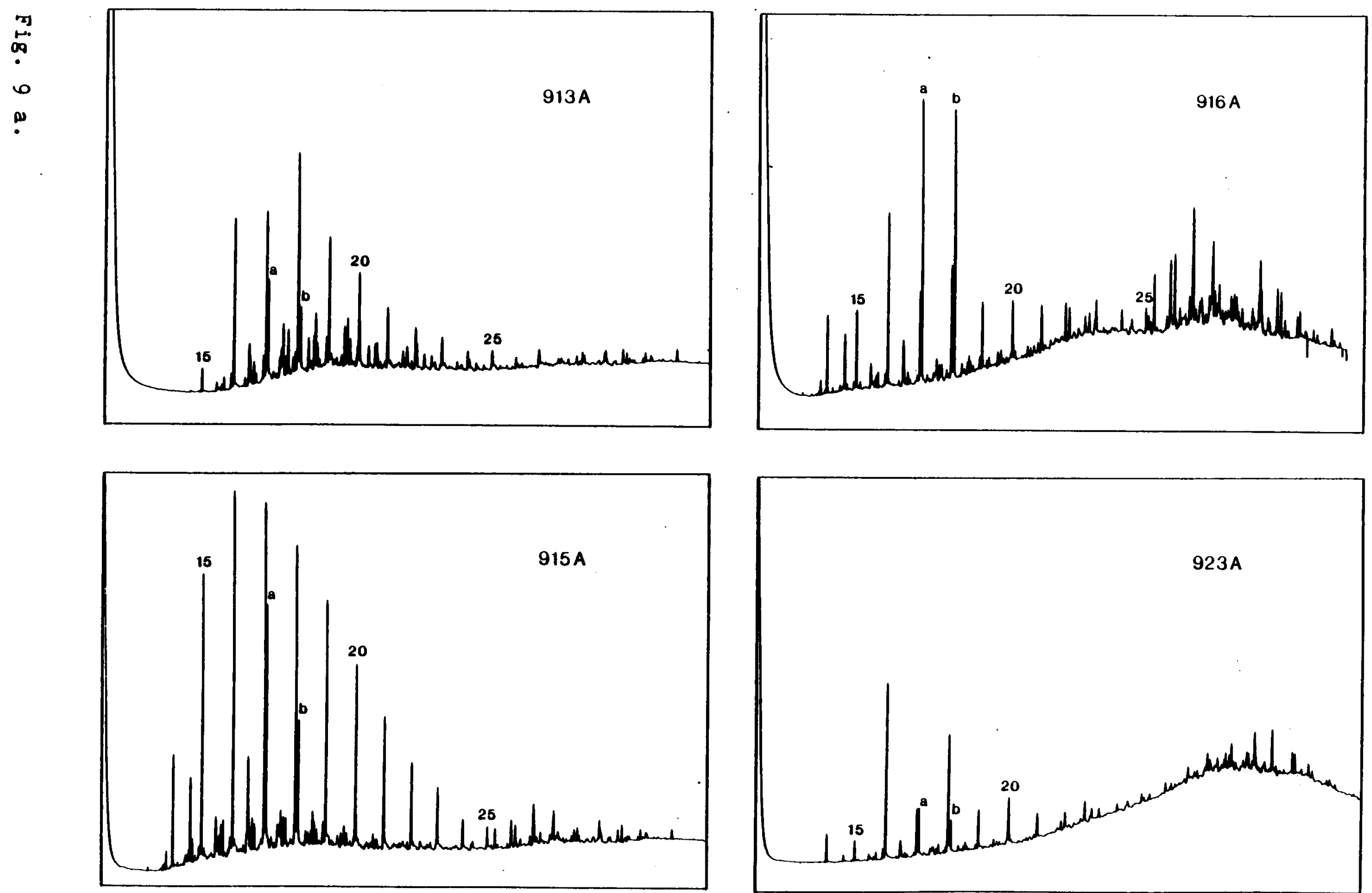

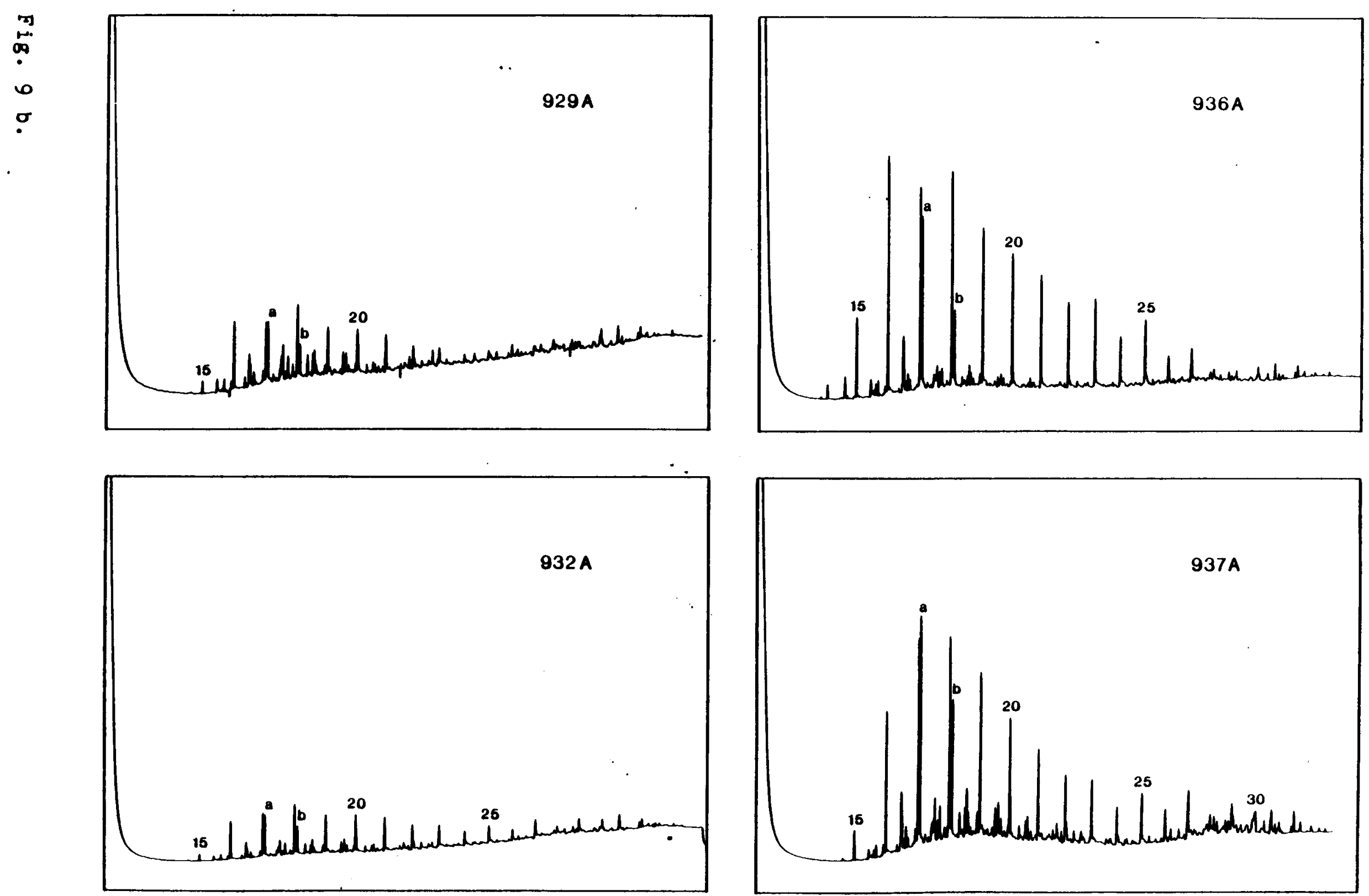

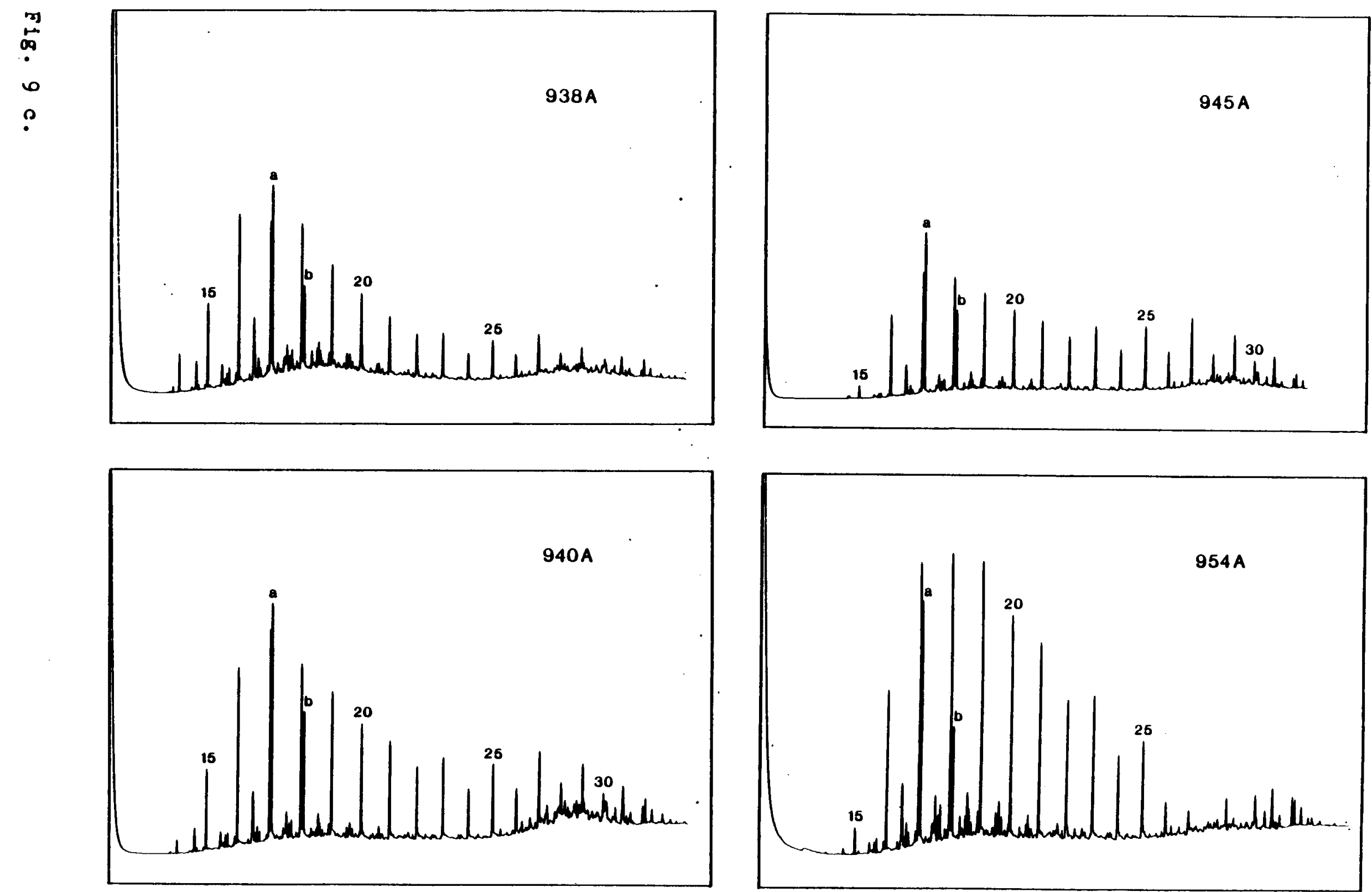

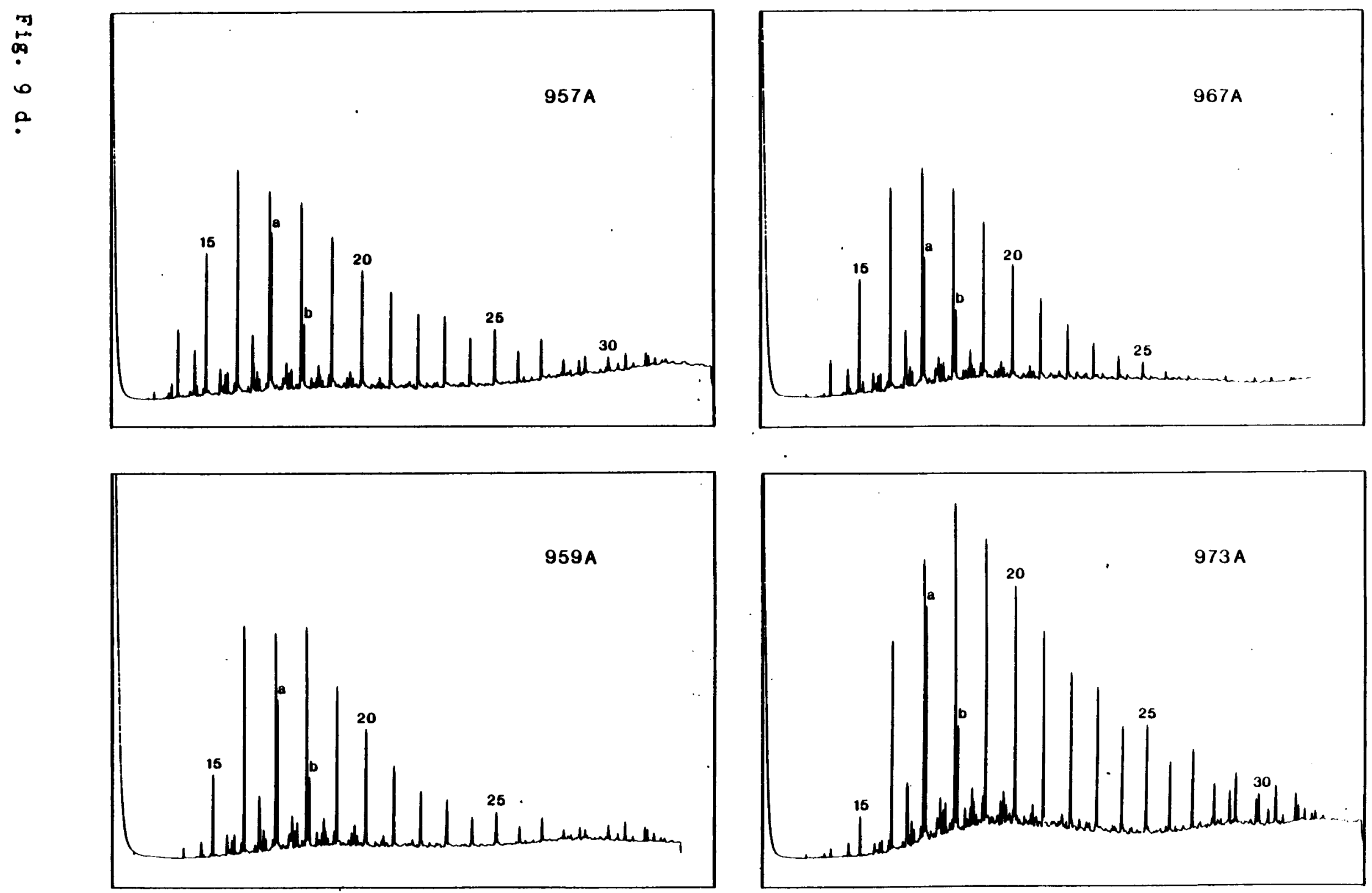

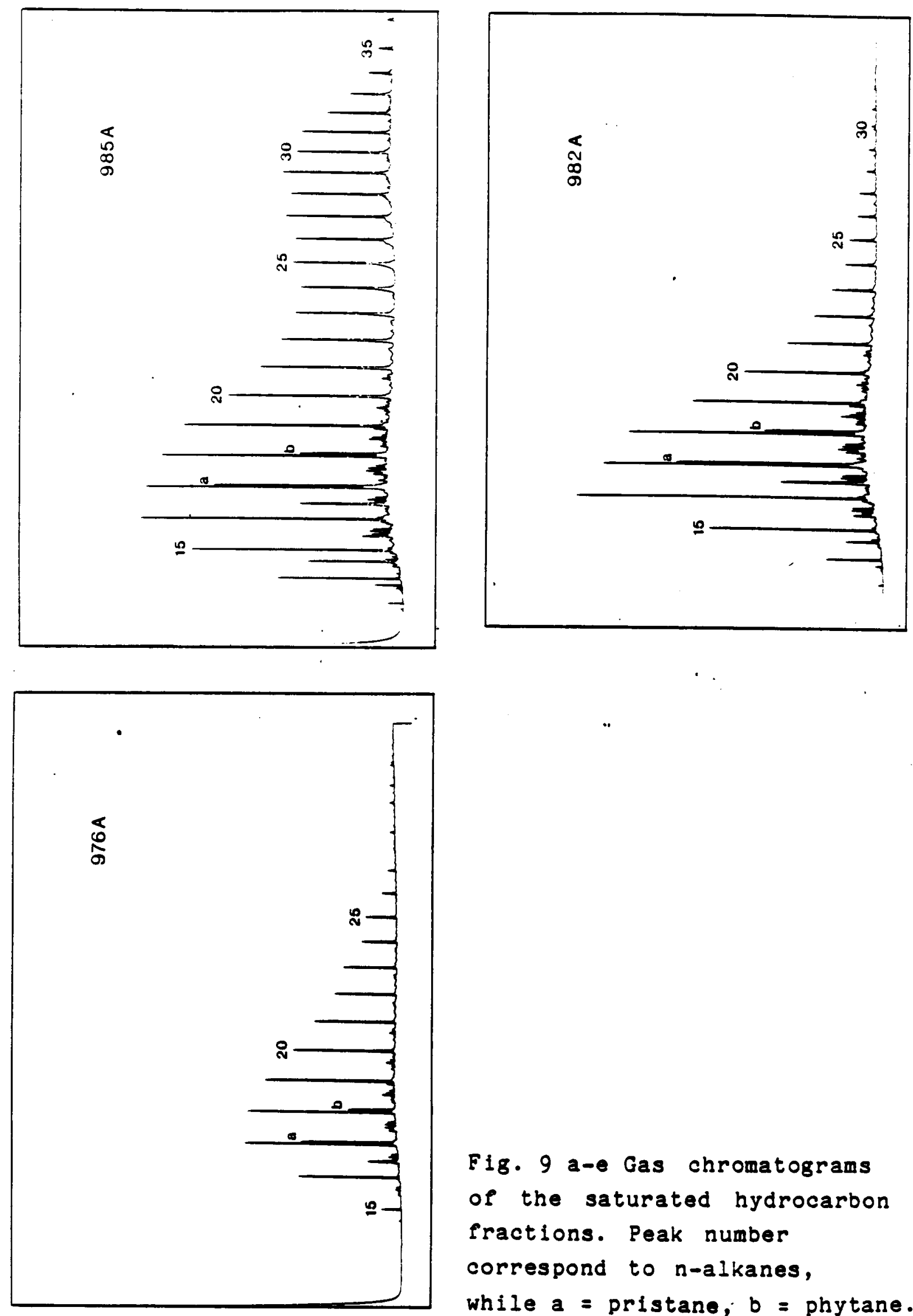

Fig. 9 a-e Gas chromatograms of the saturated hydrocarbon fractions. Peak number correspond to n-alkanes, while $a=$ pristane; $b=$ phytane. 
discussed previously. In these gas chromatograms the n-alkanes in the low molecular weight range are dominant with a maximum at $n-C_{17}$ typical of marine algal material. Only a few small peaks in the higher molecular range $>n-C_{23}$ are seen (indicative of terrestric input). This is in ${ }^{23}$ good accordance with the marine type of sediments and the visual appearance of $915 \mathrm{~A}$ (dinoflagellates can be identified among the alginites) while in $913 \mathrm{~A}$ the terrestrial input appears to be more prominent.

The Bream Formation is represented by gas chromatograms of samples 929A and 932, which only show small peak intensites because of the small amounts of hydrocarbon extracts available. In $929 \mathrm{~A}$ only short chain alkanes were detected with $n-C_{17}$ predominant, indicative of marine phytoplankton, whilst in $932 \mathrm{~A}$ longer chain $n-a l k a n e s$ with a prominent $n-C$ peak were also detected, indicating some mixing with organic matter of terrestrial origin. This terrestrial input is not confirmed by the microscropic observations. In both samples a dominance of marine algal material is seen under the microscope (some dinoflagellates are observed) in accordance with the marine-dominated nature of the sediments.

The Haldager Formation: No samples of this formation have been analysed.

The Fferritslev Formation is represented by samples $936 \mathrm{~A}$, 937A, 938A, 940A, 945A, 954A, 957A, 959A and 967A.

In the gas chromatograms of $936 \mathrm{~A}$ (transition from the Haldager Formation to F-4 Member) n-alkanes in the low molecular range with a $n-C_{17}$ maximum are dominant, indicating a high contribution of marine algal material. Under the microscope, the terrestrial contribution seems larger due to some large angular huminite/vitrinite particles. These may be flooded into the marine environment. The gas chromatograms from the other samples from the F-4 and F-3 Member (937-945) are rather similar. They show a slightly bimodal n-alkane distribution with a high maximum at $\mathrm{n}-\mathrm{C}_{17}$ and a 
smaller one at $n-C_{27}$, indicating varying proportions of a dual algal-higher plant source for the organic matter. In the gas chromatograms from the deeper samples $940 \mathrm{~A}$ and $945 \mathrm{~A}$ a slightly higher input of terrestrial material is observed compared to the upper two samples $937 \mathrm{~A}$ and $938 \mathrm{~A}$. Under the microscope these samples from the $F-4$ and $F-3$ Member also look very similar as they are dominated by liptinite composed mainly of bituminite and some recognizable alginite and sporinite. Alginite (a few algae of Tasmanites type) is seen in all samples and is probably responsible for the $n-C_{17}$ maximum. The bituminite content increases downwards in these samples and is the main organic component in the lowermost two samples. As there is only a minor contribution of huminite/vitrinite in these samples, it is assumed that at least some of the bituminite is of terrestrial origin, providing the high molecular weight range n-alkanes.

The gas chromatograms from samples $954 \mathrm{~A}-967 \mathrm{~A}$ (F-2 and F-1 Member) are relatively similar. In all samples short chain alkanes are clearly dominant, with prominent $n-C_{17}$ peaks. Only. a few small peaks were detected beyond $n-C_{25}$. (especialIy seen in $957 \mathrm{~A}$ and $959 \mathrm{~A}$ ). The prominent $\mathrm{n}-\mathrm{C}_{17}{ }^{25}$ peaks (some evaporation is seen in 954A) might indicate a considerable marine phytoplankton origin for the organic matter, which is consistent with the marine sediment type. Under the microscope most of the organic matter seems to be of terrestrial mainly reworked which thus may not have contributed to the extract. Silghtly increased maturity is seen in $967 \mathrm{~A}$ (no CPI-calculation was possible) compared with the others.

The Gassum Formation is represented by samples $973 \mathrm{~A}$ and 976A. Like the preceeding gas chromatograms, $973 \mathrm{~A}$ and $976 \mathrm{~A}$ are dominated by n-alkanes in the low molecular weight range. However $973 \mathrm{~A}$ is also associated with several small peaks of longer chain n-alkanes beyon $n-C_{25}$ (normally derived from higher land plant material). $973 \mathrm{~A}$ is notable for its content of a few microscopically identifibale coal particles. But the terrestrial input is not particularly significant in the gaschromatogram. This may be due to the 
HYLLEBJERG 1

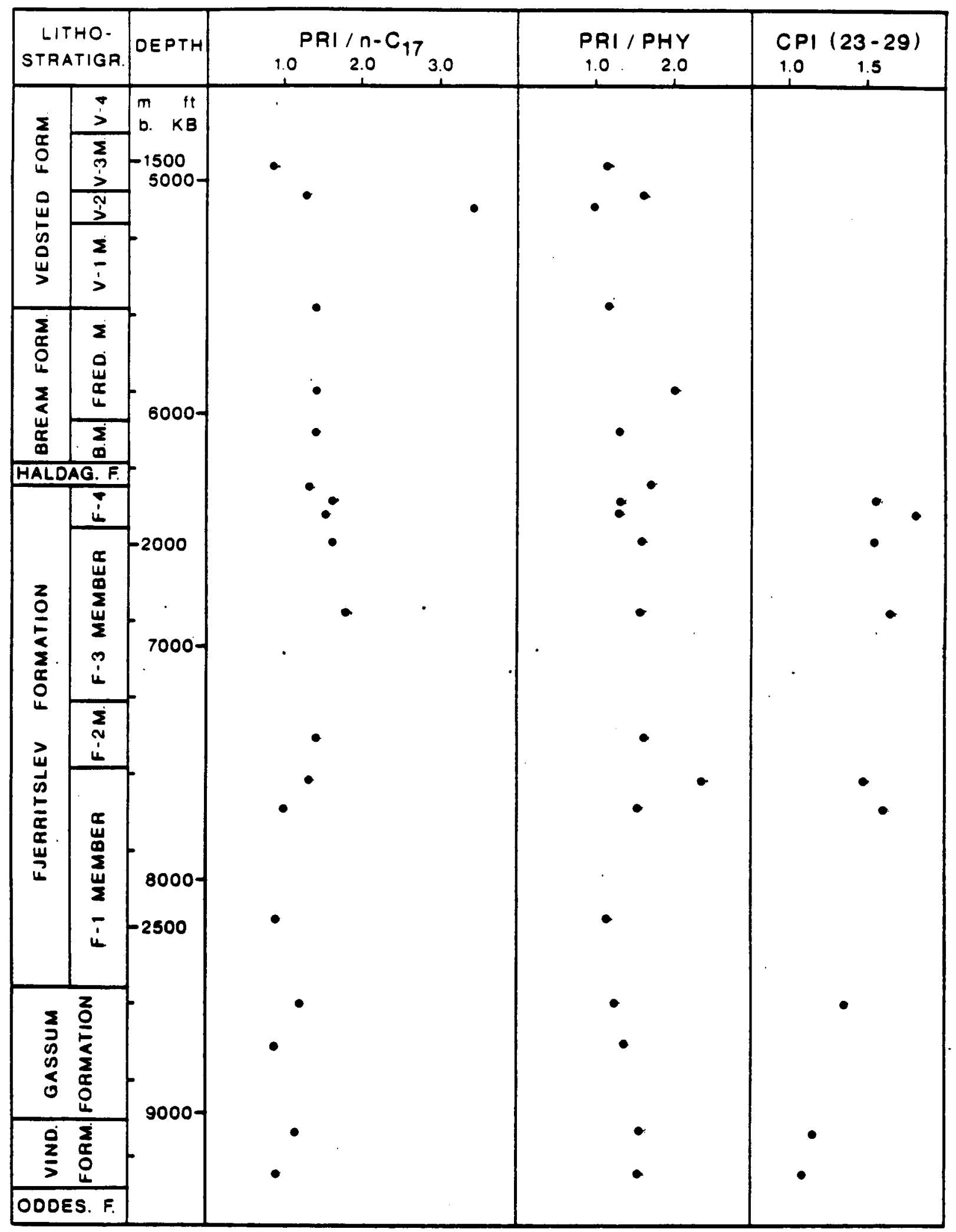

Fig. 10 Calculated maturity indices obtained from quantified peak areas in the corresponding gas chromatograms. 
fact that only very small amounts of the organic matter may have been extracted from the terrestrial material and that the terrestrial influence has been overestimated optically. It may also be caused by the small amount of extract available and thus not optimal analysis. The gaschromatogram of sample $976 \mathrm{~A}$ resembles the former but with a more smooth n-alkane distribution curve with an only slightly discernible odd-predominance. The CPI cannot be calculated.

The Vinding Formation is represented by gas chromatograms $982 \mathrm{~A}$ and $985 \mathrm{~A}$.

$982 \mathrm{~A}$ closely resembles $976 \mathrm{~A}$ as it is mostly dominated by shorter chain n-alkanes, though small peaks of longer chain $n$-alkanes can be detected up to $n-C_{31}$ (indicating at least some input of terrestrial higher plant material). Under the microscope, a rather mixed organic matter composition is seen. In the gas chromatogram the dominance of the n-alkanes in the low molecular range and the almost non-existent odd carbon number predominance must reflect increased maturity which restricts further differentiation of the organic composition.

The gas chromatogram from 985A is very different from all the others in showing a clear bimodal distribution of the n-alkanes with a very high proportion of the long chained $n$-alkanes up to $n-C_{36}$. In the low molecular range the $n-C_{1}$ peak is (according to the integrated peak areas) slightiy predominant, indicating fresh water plant material (Hutton et al. 1980). In the high molecular range the prominent $n-C_{29}$ peak normaliy indicates a higher land plant material. It can alternatively be derived from the fresh-brackish water algae Botryococcus (Hutton et al. 1980). This source is confirmed as under the microscrope a liptinite dominance is seen, mainly composed of Botryococcus-like algae. The lowered CPI-value close to 1 reflects a mature sediment.

The Oddesund Formation: No samples from deposits belonging to this formation have been analysed. 
Maturity indices:

The CPI-index was originally proposed by Bray \& Evans (1961) who calculated it as the ratio of the sum of the percentages of $\mathrm{C}_{25}{ }^{-C_{33}}$ odd-carbon n-alkanes to the sum of $\mathrm{C}_{26}{ }^{-C_{34}}$ evencarbon n-alkanes. In this study only a few gas chromatograms showed long chain n-alkanes in excess of $\mathrm{n}-\mathrm{C}_{30}$, and as the reliability is decreased in the peak area calculation of smaller peaks, the CPI indices were calculated for $\mathrm{C}_{23}{ }^{-C_{29}}$ :

$$
C P I=\frac{1 C_{23}+C_{25}+C_{27}+\frac{1}{1} C_{29}}{C_{24}+C_{26}+C_{28}}
$$

CPI-indices have not been calculated for all samples, since longer chain n-alkanes derived from terrestrial material are not always present.

In the gas chromatograms an increased maturity can be observed from the base of the Fjerritslev Formation downwards, indicated by the smoothing of the n-alkane distribution curves. This is also reflected in the CPI-values.

The data show a clear lowering in the add-even carbon number predominance of the higher n-alkarres with a decreasing trend in CPI-values from about 1.6 at the top of the Fjerritsiev Formation and approaching 1.1 in the deeper samples of the well. CPI-calculations were not possible for the relatively mature-looking gas chromatograms from samples 967A and 976A.

According to Tissot \& Welte (1984) CPI-values above 1.5 always refer to relative immature sediments, Waples (1980) sets a value of 1.2. The Fferritslev and Gassum Formation values seem to reflect immature sediments whilst an increased maturity is indicated from the values of the $V$ inding Formation sediments. These results are in good agreement with the maturity estimations from extraction data, but in sight contradiction with the vitrinite reflectance analysis, if $0,55-0,608 \mathrm{R}$ is used as threshold for the onset of the oil generation. Maturity may be reached at a greater depth than indicated from the reflectance measurements. This discrepancy may be due to the fact that the CPI-indices, as well as the amount and composition of the extracts, is related to the original composition of the organic material 
while reflectance is only related to the change of vitrinite.

In this study there are only small differences in the pristanel $n-C_{17}$ ratio. This ratio increases slightly in the upper part of the well, followed by a slight decrease of the ratio in the lower part of the well.

Thus the index seems not to be usefull as no clear indications can be obtained either for environmental conditions or for maturity.

From the pristane/phytane ratios in this study no clear evidence is generally obtained to indicate the palaeoenvironmental conditions during deposition of the sequence. No pronounced high or low values are detected. Most samples have values around 1.5 , indicating non-oxidized to mildly oxidized material (typical for a "normal" marine environment). Only a few samples (929A (Bream Formation) and 957A (Fjerritslev Formation, F-1 Member)) have values of 2 or higher, indicating more oxidized organic content, but this does not generally correspond with other observations and data. Some of the pristane/phytane ratios may be too low, such as for sample 937A. This may be caused by laboratory evaporation of the lighter component pristane, which is more volatile than phytane, or it may be caused by imperfect integration of the peak areas of the gas chromatograms.

Hydrocarbon potential;

Most of the gas chromatograms seem to indicate sediments with a main potential for oil as they show a high proportion of n-alkanes in the lower molecular weight range with maxima at $\mathrm{n}-\mathrm{C}_{17}$, typical for phytoplankton material. On the other hand, under the microscope most of these samples seem to be mainly composed of terrestrial material, often with a more or less reworked appearance ("pseudovitrinite") with only a minor liptinite contribution (as is especially seen in the Vedsted Formation and the lower part of the Fjerritslev 
Formation F-1, F-2 and deeper F-3 Member sediments). This seeming discrepancy may be attributed to the fact that much of the terrestrial organic matter is practically inert and yields little or no extract. The gas chromatograms therefore mainly represent the liptinite component. The hydrocarbon potential in these sediments must therefore be downgraded. Alternatively, the small liptinite fragments may have been underestimated during optical description, as they are sometimes hardly visible under the microscope (submicroscopic).

The gas chromatograms of the upper Fjerritslev Formation (F-4 and upper F-3 Member) seem to indicate a potential mainly for oll (also indicated by the relatively high microscopic liptinite content of bituminite and alginite), although especially in the F-3 Member some terrestrial organic material, representing the secondary maximum in the high molecular weight range of the n-alkanes (presumably derived from some of the bituminite seen under the microscope) may show a lower potential for liquid hydrocarbons, maybe for a high-waxy oll or even ?gas.

Thus the potential for liquid hydrocarbons seems to decrease downwards in the sediments of the Fjerritslev Formation. In the deeper part of the well (approximately from the base of the Fferritslev Formation and downwards) an increasing maturity of the extracts can be observed in the gas chromatograms although, according to the amount and composition of the extracts and the CPI-values, clear evidence for mature sediments is first present in samples from the Vinding Formation. The gas chromatograms tend to become similar, and differentiation of the origin of the organic matter and assessment of the hydrocarbon potential becomes increasingly difficult. This seems particularly valid for the Gassum Formation sediments where the terrestrial input seen under the microscope can not be identified with certainty in the corresponding gas chromatograms.

A bimodal n-alkane profile, with maxima centered at $n-C$ and $n-C_{29}$, occurs in the gas chromatograms, for one particular sample ( $985 \mathrm{~A})$ from the Vinding Formation. Although the 
$C_{23}$ n-alkanes are usually considered to be derived from higher plant lipids, this is not true for the present sample as microscopical observation reveals a fresh/brackish water algae (Botryococcus-like) origin which is oil prone, giving a high waxy type oil (McKirdy el al. 1986). Thus, according to the type of organic matter, in the Vinding Formation some horizons seem to possess a good potential for oil, though the potential may be reduced because of the low organic content.

Gas chromatography - mass spectrometry of biomarkers

Since all the samples selected for analysis were rich in hopanes, most information was obtained on this particular type. (The steranes were present in too low concentration for analysis). Gaschromatographic-mass spectrometric analyses were concentrated on determination of the mass fragmentograms for $\mathrm{m} / \mathrm{z} .191$ and the results are shown in f1g. 11a-b.

The relative abundance of the $17 \mathrm{~B}(\mathrm{H}) 21 \mathrm{~B}(\mathrm{H})$ hopanes $(=\mathrm{BB}$ hopanes) is shown in table 6 . The average ratios $22 \mathrm{~S} / \mathrm{S}+22 \mathrm{R}$ og the $\mathrm{C}-22$ diastereoisomers in the range of $\mathrm{C}_{31}-\mathrm{C}_{34}$ of the $17 \alpha(H) 21 B(H)$-hopanes ( $=\alpha \beta$ hopanes) were calculated and are listed in table 6. For quantification of the epimerisation of the $C-22$ position in the $\alpha \beta$ hopanes, ideally the $C$ hopane diastereoisomers should be used. The $C_{31}$ isomers should be avoided as coevolution of other triterpanes with the 22R isomer can occur under certain conditions (Mackenzie 1984). Besides this, the different isomer pairs all have slightly different equilibrium constants.

As in this study the $C_{31}$ isomers are the most abundant components, while the other isomer pairs only occur in smalier quantities, the four stereoisomer pairs of $\mathrm{C}_{31}-\mathrm{C}_{3}$ were used for calculation of an average ratio. In a few of the upper samples (913A, 915A and 940A) only the isomer pairs of the $C_{31}$ and $C_{32}$ were detected in sufficient quantities to be used for calculations. In a few samples ( $913 \mathrm{~A}$, 
916A, 932A) either very small amounts were generally available for calculation, or coevolution occurred so that the results were unreliable.

In the m/e 191 fragmentograms not all the possible hopane configurations $(17 \mathrm{~B}(\mathrm{H}), 21 \mathrm{~B}(\mathrm{H})$ and $17 \mathrm{~B}(\mathrm{H}), 21 \mathrm{~A}(\mathrm{H})$ and 17 $\alpha(H), 21 B(H)$ ) were detected in all samples.

The hopane distribution pattern clearly changes downwards from 915A to $967 \mathrm{~A}$ :

High proportions of BB-hopanes are still present in $913 \mathrm{~A}$ and $915 \mathrm{~A}$ but the content decreases until $940 \mathrm{~A}$, and no BB-hopanes are detected at greater depths.

The $\alpha \beta$-hopanes are present in all samples, clearly showing increased epimerisation downwards of the 22R-isomer to the $22 \mathrm{~S}$-isomer in the $\mathrm{C}_{31}-\mathrm{C}_{34}$ range.

The $22 S / 22 S+22 R$ ratio increases from 0.30 in $915 \mathrm{~A}$ to 0.59 in $967 \mathrm{~A}$. In the upper samples (913A-940A) the $22 \mathrm{R}$ configuration is still dominant, but in $959 \mathrm{~A}$ the 225 configuration is approaching equilibrium (sequal amount) with the $22 R$ configuration, and from $967 \mathrm{~A}$ down to $985 \mathrm{~A}$ the $22 \mathrm{~s}$ configuration is dominant. In these samples from the deeper part of the well the final mixture of the $22 S$ and $22 R$ isomers seems to be reached with an isomerisation of 55-598, ind1cating that equilibrium has been reached (Mackenzie \& Maxwell 1981). Thus from 967 A downwards no further differences in the maturity of the sediments can be detected. In this area other chemical maturity parameters should be used, such as the isomerisation of the steranes, but they occur in too low concentrations to be taken into consideration. The

Ba-hopanes were also detected between the ab-hopanes, but they were not quantified.

Compared with the results of Mackenzie (1984) (fig. A-4) it is surprising that the least stable hopanes, the $B B-$ hopanes, are still present in the upper sequence of the well. According to Mackenzle (10c. cit.) the BB hopanes (analysed erom the Paris Basin) disappear at an earlier stage of the isomerisation of the $\alpha \beta$-hopanes than that which seems to have been passed in this study, according to the reflectance 

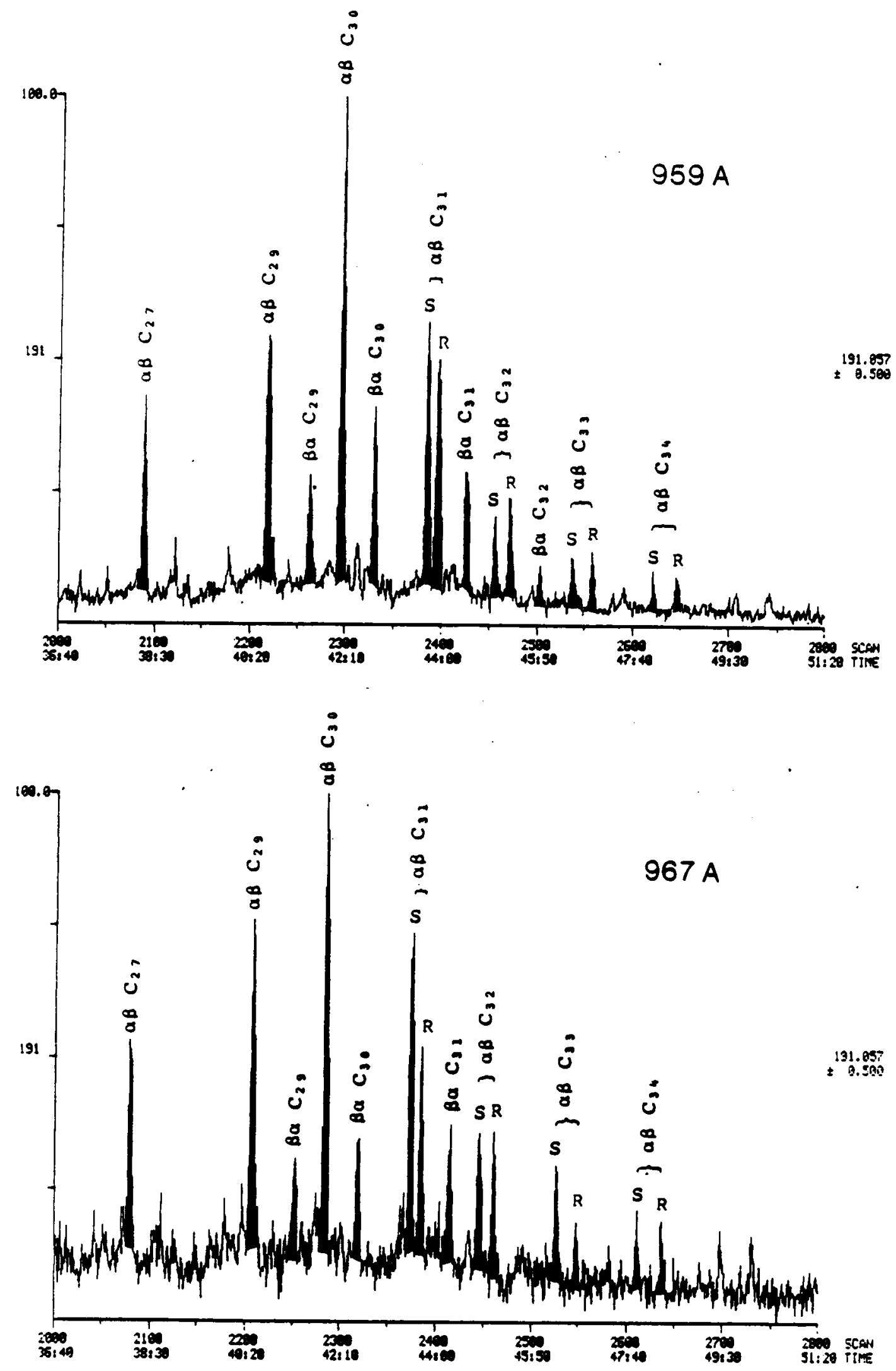

Fig. 11 a Examples of hopane fragmentograms $(m / z=191)$. 

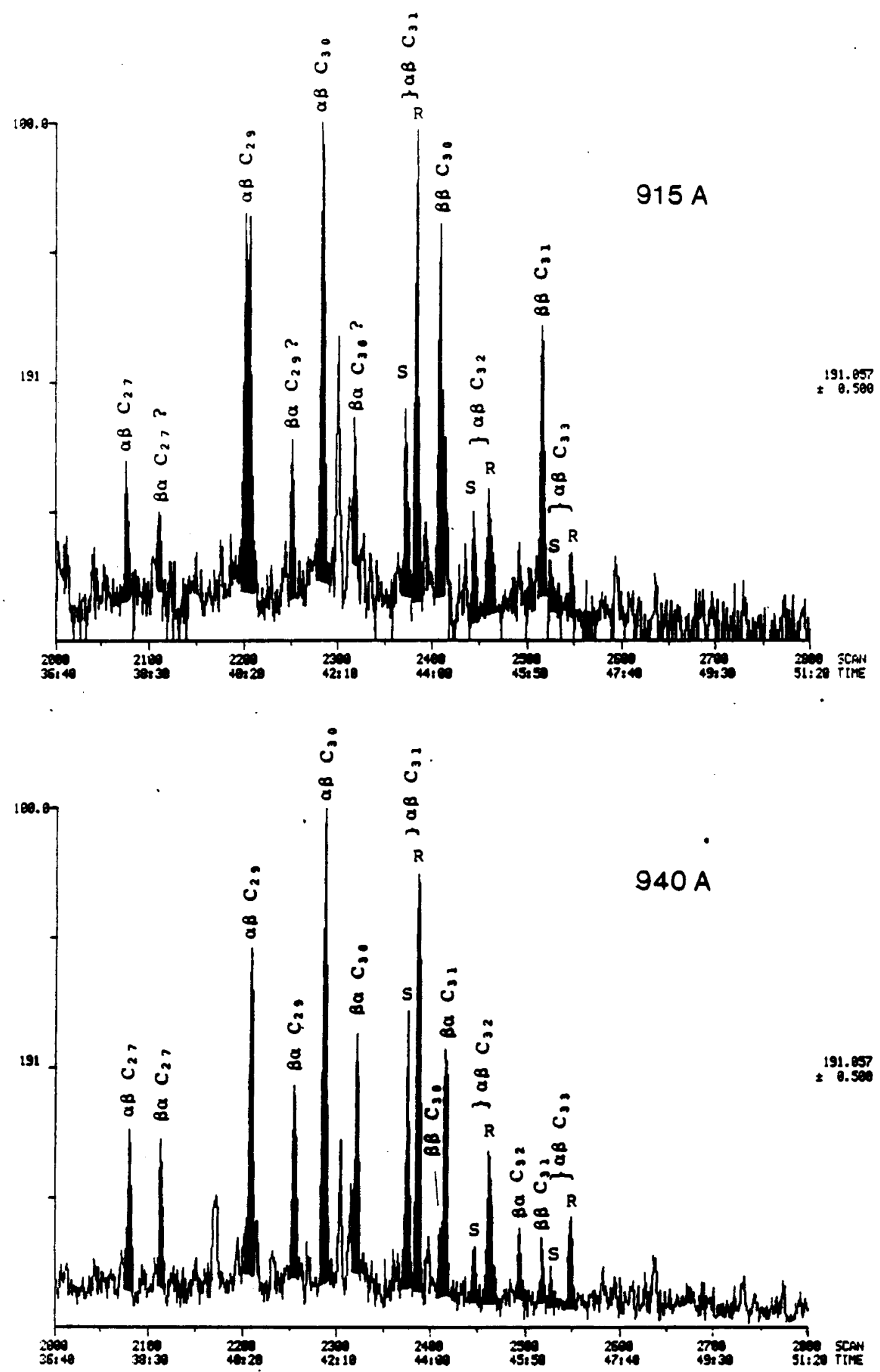

Fig. 11 b Examples of hopane fragmentograms $(m / z=191)$. 
measurements of the corresponding samples. The isomerisation ratios of the $\alpha \beta$-hopanes, on the other hand, seem to be in good agreement with the reflectance measurements. The equilibrium mixture of the $S$ and $R$ isomers is reached at approximately $8200^{\circ}$ depth, equivalent to a vitrinite reflectance value of about $0.57 \% \mathrm{R}$ which indicates that the zone of hydrocarbon generation has not been reached. This is in good accordance with Seifert \& Moldowan (1980) and Mackenzie \& Maxwell (1981) as isomerisation may be completed before the zone of significant hydrocarbon generation is attained. 
The various methods used to assess the source rock potential and maturity of the investigated Mesozoic sediments indicate, that maturity seems to be reached at different depths. The vitrinite reflectance measurement is the most widely used standard method always used for correlation of maturity parameters, though vitrinitic organic material itself is not oil prone. Whilst the other organic chemical methods mainly reveal the maturity of the oil prone organic matter. Thus discrepances arise from the results of the different used techniques. An important factor is that relatively few data were avalable in this study. Blomarker analyses may be useful although isomerization of the hopanes did not help resolving maturity problems as the maturity of the sediments had passed the level where the final equilibrium mixture of the C-22 diastereoisomers of the $\alpha \beta$-hopanes was reached. Analyses of the steranes would be useful to elucidate the maturity conditions at this level, but the concentration of the steranes was too low for further investigations.

The type of the organic matter and its hydrocarbon potential were estimated by optical characterization of the organic composition and gas chromatographic analysis of the extracted bitumen combined with TOC-analyses. A combination of these methods helped in the recognttion of reworked/oxidized, contaminated, biodegraded material, and to resolve seeming discrepancies in the gas chromatographic and microscopic results.

The composition and amount of organic matter indicate some sequences with potential source rock characteristics in the investigated Mesozoic sediments. These sediments may act as source rocks if sufficient maturity is attained.

Sediments with the most promising source rock charac- 
teristics occur in the F-4 and upper F-3 Member of the Fjerritslev Formation. The organic content of these lagoonal and deep water marine sediments is relatively high in some horizons where it is mainly composed of liptinite (bituminite and alginite) normally regarded as good source material for oil. But according to the gas chromatograms some of the bituminite seen under the microscope (especially in the F-3 Member) may be of terrestrial origin which may lower the hydrocarbon potenital.

Most of the other sediments (especially from the Vedsted and the lower part of the Fjerritslev Formation) are relatively unfavourable with respect to hydrocarbon generation, though the gas chromatograms show good quality material with respect to oil. However, under the microscrope the main part of the organic matter is seen to be composed of reworked/ oxidized terrestrial material with very limited hydrocarbon potential. Thus the potential for liquid hydrocarbons decreases. in the sediments from the F-4 to the F-3 Member and downwards in the Fjerritslev Formation.

In the Vedsted Formation, only one sample with a high organic content composed of bacterial reworked organic matter may indicate an anoxic event with deposition of sediments with an increased hydrocarbon potential.

The principal source rocks of the North Sea graben structures are organic-rich "black" shales erom the Rimmeridge Clay Formation and its lateral equivalents the Borglum Member of the Bream Formation and the $\mathrm{J}-4$ unit (Barnard \& Cooper 1981, Michelsen 1982, Cornford 1984). The equivalent Upper Jurassic sediments of the Bream Formation in this well do not show similar prominent source rock characteristics, though a higher proportion of liptinite (algal material) is observed.

Most of these sediments may be excluded as actual source rocks as maturity, according to the vitrinite reflectance measurements and assuming $0.60 \% R$ as the threshold value for the top of the "oll window" is first reached at $8500^{\circ}$, approximately at the top of the Gassum Formation. The base of the "oil window" at approximately $1.3 \mathrm{~s}_{0}$ may, by extra- 
polation of the reflectance trend, be predicted at 17,400' (presumably in Triassic redbeds). Thus the mature sediment sequences with respect to oil generation may be thinner and at slightly shallower depth in the central part of the Danish Subbasin than in the marginal areas (Lindgreen \& Thomsen 1982). This is attributed to a slightly higher geothermal gradient and higher heat flow in the central part of the basin compared to the areas outside the basinal depocenter. While maturity seems to be reached in the deeper part of the well, no commercial accumulations of hydrocarbons have so far been encountered. The reasons for this may be numerous. The upper threshold values of the oll window should perhaps be set af higher $\mathrm{h}_{\mathrm{R}}$-vaules, as according to the extraction data (amount and composition of the organic matter) maturity may first be reached in the Vinding Formation. Alternatively, the terrestrial-influenced type of organic matter in the Gassum Formation has an unfavourable potential for oil, and/or the organic content is too low. However, generation and possible migration of gasedus hydrocarbons cannot be excluded here or elsewhere in the basin, as in the coal-measure sequences the TOC-values fluctuate considerably and organic rich sequences are likely (as they are known from other wells).

In the sediments of the Vinding Formation the type of organic matter seems to show a good potential for oil in some algal-rich horizons, but it is doubtful whether oil generation can reach commercial levels as the low organic content may be critically close to the lower limit for potential source rocks. Alternatively, hydrocarbon saturation and expulsion have not been reached and the maturity threshold value may be set at higher $R$-values.

The situation may only be slightly different off-structure in this area as the F-4 and F-3 Member sequence according to seismic sections is found at approximately the same depth. But the thickness of and the depth to the Fjerritslev Formation is increasing towards the south east into the rimsyncline of the salt domes nearby.

The deeper part of the "oll window" seems to fall within 
the continental redbed sequences and evaporites of the Triassic (Bertelsen 1980) which are unlikely source rocks. 


\section{ACKNOWLEDGEMENTS}

This study was supported by the Danish Ministry of Energy (aktst. 118. 1983 and EFP-85 project).

I am also grateful to the Danish Natural Science Research Council for financing a scholarship at Aachen Technical University, F.R.G., and to the Geological Survey of Denmark, Copenhagen, for providing the material and preparation of the specimens for microscopy.

In particular I wish to thank the staff of "Lehrstuhl fur Erdol und Kohle" (Aachen Technical University, F.R.G.), Prof. M. Wolf, H.W. Hagemann and W. Püttmann for their assistance and discussion of the results. E.Thomsen and $P$. Dstfeldt Geological Survey of Denmark are thanked for their comments on a draft version of the text, J.R. Wilson (Geological Institute, University of Aarhus) kindly improved the English text. 


\section{Lithological description}

The lithologies of the cutting samples were examined and the main lithology of each sample (washed and dried cuttings) was estimated.

Observation of the glauconite and pyrite content was done in the polished specimens under the microscope.

\section{Optical coal petrographic methods}

Vitrinite reflectance measurements

Introduction

In reflected light the maturity/rank of the organic matter in the sediments can be determined by reflectance measurements on the dispersed organic particles belonging to the maceral group of huminite/vitrinite. Huminite/vitrinite particles are used as they are the main maceral group in humic coals and also occur widely in sediments of different lithologies and facies; they also mature regularly. Care must be taken in the choice of particles for measurements (Bostick 1974, 1979). The dispersed organic matter in the sediments usually consists of a mixture of various types of autochtonous and reworked, or in other ways altered, products with a large-reflectance range. Only the least altered particles represent the indigenous maturity of the rock and must be selected for measurements. In the huminite/vitrinite group many higher reflecting particles represent transitions 
to the inertinite group (counted here as pseudovitrinites) giving too high reflectance values, while other very low reflecting particles belong to the bituminous or "A"-types of huminites giving too low reflectance values. As many low reflecting huminite/vitrinite grains as possible must be recorded in each sample (Stach et al. 1982, Lindgreen \& Thomsen 1982). The measurements are presented in histograms and only the lower reflecting huminite/vitrinite are chosen as representing the autochtonous material.

Here some samples with coaly particles, whose reflectance results are unequivocal, are used as marker horizons to determine the realistic reflectance range.

Though huminite/vitrinite generally is not oil prone material, the huminite/vitrinite reflectance is now the most widely used optical technique in the petroleum industry for determining the maturity of sediments (Hunt 1979, Tissot \& Welte 1984). Reflectance increases with increasing maturity, and the following stages can be distinguished (Tissot \& Welte, 1984):

a) $\bar{R}_{0}<0.5$ to $0.7 \%$ diagenesis stage; source rock immature; Hydrocarbons scarce.

b) 0.5 to $0.7 \%<\bar{R}_{0} \quad<$ ca.1.3\% catagenes is stage; source rock mature; main zone of oil generation ("oil window").

c) ca. $1.3 \&<\bar{R}_{0}<2 \&$ catagenesis stage; source rock post mature with respect to oil generation; zone of wet gas and condensate.

d) $\bar{R}_{0}>2 \%$

metagenesisstage; methane remains as the only hydrocarbon; dry gas zone.

The boundaries of the oil and gas zones change slightly 
according to time-temperature relationships and according to the composition (type) of organic matter (fig. A-1).

Sample preparation

Small cutting samples were sent to the Coal Petrographic

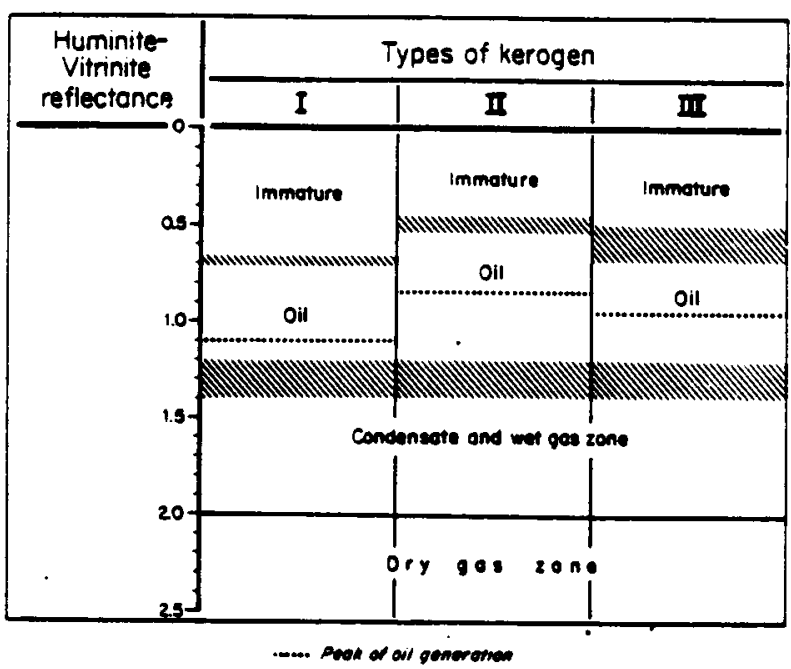

1. Fig. A-1: Approximate boundaries of the oil and gas zones in terms of vitrinite reflectance. Boundaries may change slightly according to the time-temperature relationship, and also to the various types of organic matter. Reprinted from Tissot \& Welte (1984), with permission.

Laboratory, Danish Geological Survey, Copenhagen, for preparation of the specimens for microscopy.

The samples were imbedded in a cold setting synthetic resin, followed by grinding and polishing using $1 / 4$ micron diamond powder for the final polish. All grinding and subsequent polishing stages were carried out using DP Lubricant Blue (Struers), since water causes swelling and disintegration of the clay content of some samples. 
Instruments

All polished sections were studied in reflected light by means of a "Zeiss Photomicroscope" equipped with a 40x "Epipol" oil immersion objective, an adjustable lamp current stabilizing transformer with a $100 \mathrm{~W}$ halogen lamp, filters for green light $(546 \mathrm{~nm})$ and a MPO3 photomultiplier with digital read-out, connected to a BBC computer. The photomultiplier was calibrated on the microscopy by measurements on a polished optical glass standard of constant known reflectance. The measured field was about 2 microns in diameter.

Qualitative description of the organic matter

The type of organic matter influences the quality and quantity of the hydrocarbons which may be generated if sufficient maturity is reached. Liptinitic plant material (especially of phytoplankton origin) shows a good potential for oil

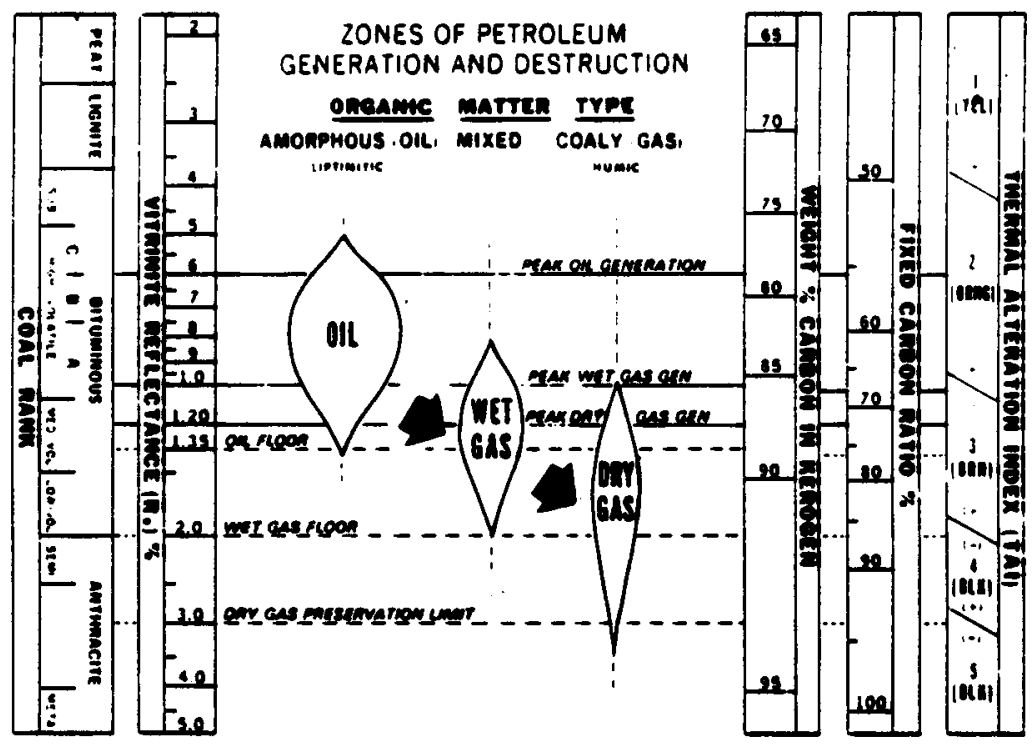

2. Fig. A-2: Correlation scheme of vitrinite reflectance and other maturity parameters with the main stages in the generation of ofl and gas.

The importance of the type of organic matter for the resulting hydrocarbon product is illustrated for liptinite, mixed and humic type of organic matter. Reprinted from Dow (1977a), with permission. 
while humic material (huminite/vitrinite) derived from terrestrial plants generally has a main potential for gas. Reworked/oxidized material (inertinite, pseudovitrinite) shows a very limited or no potential for gas. This is illustrated in fig. A-2 (Dow 1977a) (p.37).

The type of organic matter is rated qualitatively by reflected light microscopy, supplemented with observations on blue-light induced fluorescence performed on the same polished mounts as used for reflectance analysis. In the description of the organic matter (see tabel 7) special attention was given to the composition and fluorescence colours of the liptinite group.

The nomenclature is in accordance with Stach et al. (1982) though in this study "huminite" and "vitrinite" are used parallel, as precise distinction between brown or bituminous coal rank particles is impossible in sediments.

The organic particles show much larger scattering in reflectance in sediments than in coals. In sediments a continous reflectance and morphological sequence exists between particles of the huminite/vitrinite group due to extensive reworking and oxidation (Bostick 1974).

These particles with somewhat higher reflectance than true huminite/vitrinite are termed pseudovitrinite in this study, although in a coal petrographic sense most of them might belong to the inertinite group.

Spectral fluorescence measurements

Introduction

If reflectance measurements on huminite/vitrinite particles are impossible (absent, rare or mainly represented by reworked particles) the fluorescence properties of the liptinite group can be used as a maturity/rank parameter. Liptinite 
components show a characteristic change in fluorescence properties with increasing rank/maturity which causes the colour spectrum to change progressively: The wavelength range of the fluorescence light moves from green-yeliow towards orange and red simultaneously with decreasing fluorescence intensity. The visible fluorescence of liptinites disappears as a maturity corresponding to the end of the oil generation zone is reached (van Gijzel 1981, Ottenjan et al. 1974, Teichmüller \& Ottenjann 1980, $981 / 1982$, Teichmüller \& Durand 1983). The fluorescence spectra can be quantified and several parameters are used as rank/maturity indicators.

Spectral fluorescence measurements are usually performed on liptinites from polished surfaces of whole rock samples. As a new analytical method, fluorescence measurements have been carried out on extracted bitumens (i.e. the soluble part of the organic matter) since the fuorescence properties of the extracts change in a similar way to the macerals of. the liptinite group (Hagemann \& Hollerbach 1980, 1981a, 1981b).

In this study this new method has been applied to some selected samples. The mean spectra (average of 10 spectral measurements) were quantified and the following parameters were used as rank/maturity indicators:

1) The red/green ratio, i.e. the ratio between the relative intensities at $650 \mathrm{~nm}$ and at $500 \mathrm{~nm}$ (the socalled Q-values) were calculated.

2) The position of the maximum of the spectrum ( $\lambda_{\max }$ ) was determined.

3) The quantitative coefficients of the corresponding fluorescence colours, the so called trichromatic coordinates (Chromaticity coefficients) $x, y$ of the ICI system (International Commision of Illumination) were computed.

Very small differences in colour are detected by this calculation as intensities over the entire spectrum (420-700 nm wavelength) account for the trichromatic coordinates.

The trichromatic coordinates are plotted graphically in a two dimensional diagram (DIN 6164 for the illumination D65) see page 20 for an explanation. 
Sample preparation

The fluorescence analyses were carried out at the "LehrstuhI für Erdöl und Kohlen, Aachen Tecnical University, West Germany.

The spectral fluorescence measurements were performed on small amounts of the extracted bitumens (Soxhlet extracted with $\mathrm{CH}_{2} \mathrm{Cl}_{2}$ ) from the same samples as used for the chemical analysis.

In order to get comparable results by quantification of the spectral curves, a precise concentration of extract was adsorbed on small glass slides covered with Kieselguhr $G$ (Merck).

Small amounts of the extract were dissolved in $20 \mathrm{ul}$. toluene/methanol ( $3: 1)$ per milligram extract.

Kieselguhr $G$ has a very low blank fluorescence value and there is no chromatographic effect for the selection of any component from the extract solution, with the exception of high asphaltic compounds. After careful evaporation of the solvent mixture under vacuum, the glass slides with the extracts are ready for the fluoresence measurements (Hagemann \& Hollerbach 1981).

Measurements were started after adjusting the optical system of the microscope and the photoelectric assembly and were performed on small uniform fluorescing diatoms. In this study the alteration effect (alteration = change of pluorescence during irradition) has not been taken into account. To achieve the minimum alteration effect, focussing is done as quickly as possible. Ten spectral curves are measured for each sample and the mean spectrum calculated, which was used for quantification of the maturity parameter.

\section{Instruments}

The Zeiss microscope was equipped with a MPN 01K photometer, a reflected-light condenser III-RS with excitation filter $G$ 365, chromatic beam splitter FT 395 and barrier filter LP 397 , a Neofluar 16/0.40 T objective, stabilized superpres- 
sure discharge lamp HBO 100 as light source for florescence excitation and a grating monochromator registrating the spectral range from 420 to $700 \mathrm{~nm}$ in single steps of $5 \mathrm{~nm}$. The measured field was $0.030 \mathrm{~mm}$ in diameter. The microscope was attached to and controlled by a HP-85 computer which also recorded the spectra. In order to obtain the real spectrum the registred fluorescence intensities were corrected for several distorting effects caused by the photometric equipment (i.e. all optical and electrical parts). In this study a stabilized tungsten-filament lamp with a flat coil $60 \mathrm{~W}, 10.1 \mathrm{~V}$, colour temperature $2850^{\circ} \mathrm{K}$ was used as comparison lamp to obtain the correction factors. The correction factors for the spectral curves were calculated based on Planck's law of radiation (Piller 1978).

\section{Organic geochemical methods}

Total organic carbon (TOC)

The amount of organic matter is estimated by organic carbon analysis.

A minimum content of organic matter is required for a sediment (under otherwise ravourable conditions) to be a source rock. Generally 0.5 \& organic carbon (TOC) has been accepted for shales ( 0.3 \& for carbonates) to be the critical lower limit, though in many laboratories the limits are set at higher values (Tissot \& Welte 1984) as the.hydrocarbon potential is only affected by the percentage of carbon which is hydrocarbon prone.

The analytical laboratory technique involves combustion of the organic carbon to $\mathrm{CO}_{2}$ in an oxidizing atmosphere in a Leco induction furnace, followed by quantitative detection of the $\mathrm{CO}_{2}$ formed and calculation of weight percent total organic carbon.

The analyses were performed on all finely ground rock samples (ca. 2 g) which had been treated with $10 \% \mathrm{HCl}$ and 
washed with distilled water to remowe any carbonates present (Tissot \& Welte 1984).

Extractable organic matter (EOM) and chromatographic separation

\section{Introduction}

Chemical analyses were performed on the extractable part of the organic matter (EOM) - also called bitumen.

The amount of bitumen in the organic matter depends on the maturity as bitumen is generated from the kerogen during thermal degradation. During maturation the composition of the bitumen changes. The amount of saturated hydrocarbons in the bitumen increases as, to a lesser degree, does the amount of aromatic hydrocarbons, while heterocompounds ( $N$, $S$, 0 compounds) decrease in concentration.

Thus the amount of the extractable organic matter (mg $\mathrm{EOM} / \mathrm{g} \mathrm{TOC}$ ) and the hydrocarbon ratios (mg $\mathrm{HC} / \mathrm{g} \mathrm{TOC}$ ) can be used as maturity indices.

Maturity is indicated by a pronounced increase in the bitumen and hydrocarbon content, but variations in the amounts of extracts and their composition are also influenced by the type of the primeval plant material. Continental plant material generally generates smaller amounts of bitumens and hydrocarbons than marine or limnic predecessors.

Extractabilitty values may also be influenced by contaminating materials from processing the well and handing the cutting materials. Pronounced high values may indicate migrated hydrocarbon materials.

\section{Extraction}

Samples were selected for extraction on the basis of the TOC determinations and the qualitative description of the microscopic organic matter. About $50 \mathrm{~g}$ finely ground material 
was Soxhlet extracted with dichlormethane $\left(\mathrm{CH}_{2} \mathrm{CL}{ }_{2}\right)$ for $48 \mathrm{~h}$ at $45^{\circ} \mathrm{C}$.

Sulphur was removed by activated $\mathrm{Cu}$-sheets in the rlasks. The solvert was distilled before use; all extraction thimbles and filter papers were pre-extracted with pure solvents to remove any soluble component. After extraction the solvent was removed at reduced pressure and temperature (not exceeding $30^{\circ} \mathrm{C}$ ) on a Rotavapor rotary evaporator. The extract was transferred, with small amounts of solvent, to small bottles. The amount of the extractable organic matter (EOM) was determined after the solvent had been completely evaporated at room temperatur.

Chromatographic separation

The extractable organic matter (EOM) was fractioned by column chromatography. The column was packed with solvent washed and preactivated $\left(1 \mathrm{~h}\right.$ at $\left.110^{\circ} \mathrm{C}\right)$ silica gel (Merck Kieselgel 60), and the upper $1 / 3$ was packed with alumina. Small portions of EOM (ca. $5 \mathrm{mg}$ ) were dissolved in a few drops of $\mathrm{CH}_{2} \mathrm{Cl}_{2}$, adsorbed on alumina by gentle evaporation and transferred to the top of the column. Fractions of increasing polarity were eluted by pouring increasingly polar solvents through the column. About $5 \mathrm{ml}$ of each solvent was used. The eluants were collected in small bottles and the varlous fractions, the saturated hydrocarbons (eluted with n-hexane), the aromatic hydrocarbons (eluted with dichlormethane), and the NSO (polar nitrogen-, sulphur-, and oxygen containing) compounds (eluted with methanol) were determined after evaporation of the solvents at room temperature. The remaining part of the extract includes asphaltenes (retained on the column) and evaporative losses during handling. The weights of the different fractions were expressed in percent. 
Gas chromatography

\section{Introduction}

The extractable organic matter includes biomarker molecules which carry information about the type and origin of the organic matter. (For the importance of the type of organic matter with respect to the quality and quantity of the hydrocarbons generated during catagenesis, see p. 64). These can be detected by gas chromatographic analyses of the saturated hydrocarbon fraction of the bitumens. Thermally induced changes in the organic matter are reflected in the gas chromatograms and some indices can be used to assess the maturity of the organic matter.

In the gas chromatograms from immature extracts, differences in n-alkane distribution patterns can be attributed to the origin of the organic matter as there are fundamental differences between the chemical composition of marine planktonic algae and terrestrial higher plants. Long chained n-alkanes are derived from lipids (especially cuticular waxes) of higher plants. They show a strong predominance of odd carbon numbered over even carbon numbered n-alkanes, especially apparent from $n-C_{23}$ to $n-C_{35}$ with a strong predominace of $n-C_{27}, n-C_{29}$ andfor $n-C_{31}{ }^{35}$ (Hunt 1968, issot \& Welte 1984). Shorter chained n-alkanes in the low-medium molecular weight range are derived from marine algae, with only slight predominance of odd-numbered n-alkanes and especially prominent $\mathrm{n}-\mathrm{C}_{15}$ and/or $\mathrm{n}-\mathrm{C}_{17^{\circ}}$. With increasing thermal maturation n-alkanes of decreasing chain lengths are formed, principally within the oll generation zone. Especially in terrestrial organic matter a heavy-end bias gradually gives way to a light-end bias in corresponding gas chromtograms, so that the odd n-alkanes of blogenic origin become progressively diluted by thermally new generated n-alkanes without carbon number predominances. The odd-dominance is thereby lowered and the chromatograms tend to become alike in well mature sediments. This odd-dominance can be quantified by the so called Carbon Preference-Index CPI (which 
stands for the ratio of odd-to even chain lenght n-alkanes in a specific high molecular weight range) and used as a maturity index (Bray \& Evans 1961). In recent sediments the CPI-index is about 2-2.5 or even higher. With increased maturity the CPI-index is lowered and gradually approaches 1.0 when peak oil generation is reached (Tissot \& Welte $1984)$.

The pristane/n-C $C_{17}$ ratio has also been used as a maturity indicator ( $T$ issot et al. 1971) as well as an environmental indicator (Lijmbach 1975).

As a function of n-alkane generation by thermal processes the pristane/n-C ratio decreases with increasing maturity (Tissot et al. 1971). The ratio is also highly dependent on the original input of organic matter and the redox potential of the depositional environment, and sensible to blodegradation. Marine algal material with a prominent $n-C_{17}$ peak will lower the pristance/n-C 17 ratio, while in a highly oxygenated environment pristane generation will be favoured and thus increase the pristane/n-C 17 ratio. Lijmbach (1975) proposed a high pristane/n-C, ratio in peat swamp environments and a low ratio in aquatic environments.

The acyclic isoprenoids pristane and phytane can be used as environmental indicators. Pristane and phytane are considered to be end products of the diagenesis of the phytol side chain of chlorophyll, their relative abundance depending on the local environment (Powell \& Mckirdy 1975, Brooks 1969). In oxidizing environments phytol is mainly transformed to pristane while reducing environments favour the generation of phytane. Thus differences in the pristane/phytane ratios (typically > 3) indicate oxidizing environments of land derived organic matter or organic matter which has passed through an oxygenated phase during decomposition while low pristane/phytane ratios (typically < 1.5 ) indicate reducing environments with anaerobic decay.

The pristane/phytane ratio is influenced by thermal processes as pristane is progressively generated during the late stages of diagenesis and early stages of catagenesis. As a result the pristane/phytane ratio increases slightly 
during maturation until the cracking zone is reached then it decreases (Tissot \& Welte 1984). Maturation processes do not readily affect the pristane/phytane ratio to such an extent that original palaeoenvironmental information is obscured (Didyk et al. 1978).

Instruments

Gas chromatoghraphic analysis of the saturated fractions (and for control also some aromatic hydrocarbon fractions) were performed on a HRGC 5160 Mega Series (Carlo Elba) instrument equipped with a 50 m glass-capillary SE 54 Column with $\mathrm{H}_{2}$ as carrier gas using the split injection technique. The effluent from the colun was detected with a Flame Ionisation detector (FID). The column temperature was increased from $100^{\circ}$ to $300^{\circ} \mathrm{C}$ at a rate of $4^{\circ} \mathrm{C} / \mathrm{min}$ and subsequently maintained at $300^{\circ} \mathrm{C}$ until the analysis was completed. Relative concentrations of the n-alkanes and the isoprenoids pristane and phytane a.o. were found by integrating the peak areas on the gas chromatograms.

Gas chromatography - Mass spectrowetry (GC-MS)

Introduction

Some samples ( 1.0 . the saturated hydrocarbon eraction) were selected on the basis of the gas chromatograms for further investigation of the blomarkers with computerized GC-MS.

Biomarkers are any organic compounds detected in the geosphere whose carbon skeletons have survived in a recognizable form through the process of early sediment diagenesis (Mackenzie 1984). Thus they can be linked to some major structural types known from biological molecules. In their structure they often contain several chiral centers 1.e. atoms around which alternative spatial arrangements of attached groups result in different stereolsomers. These 


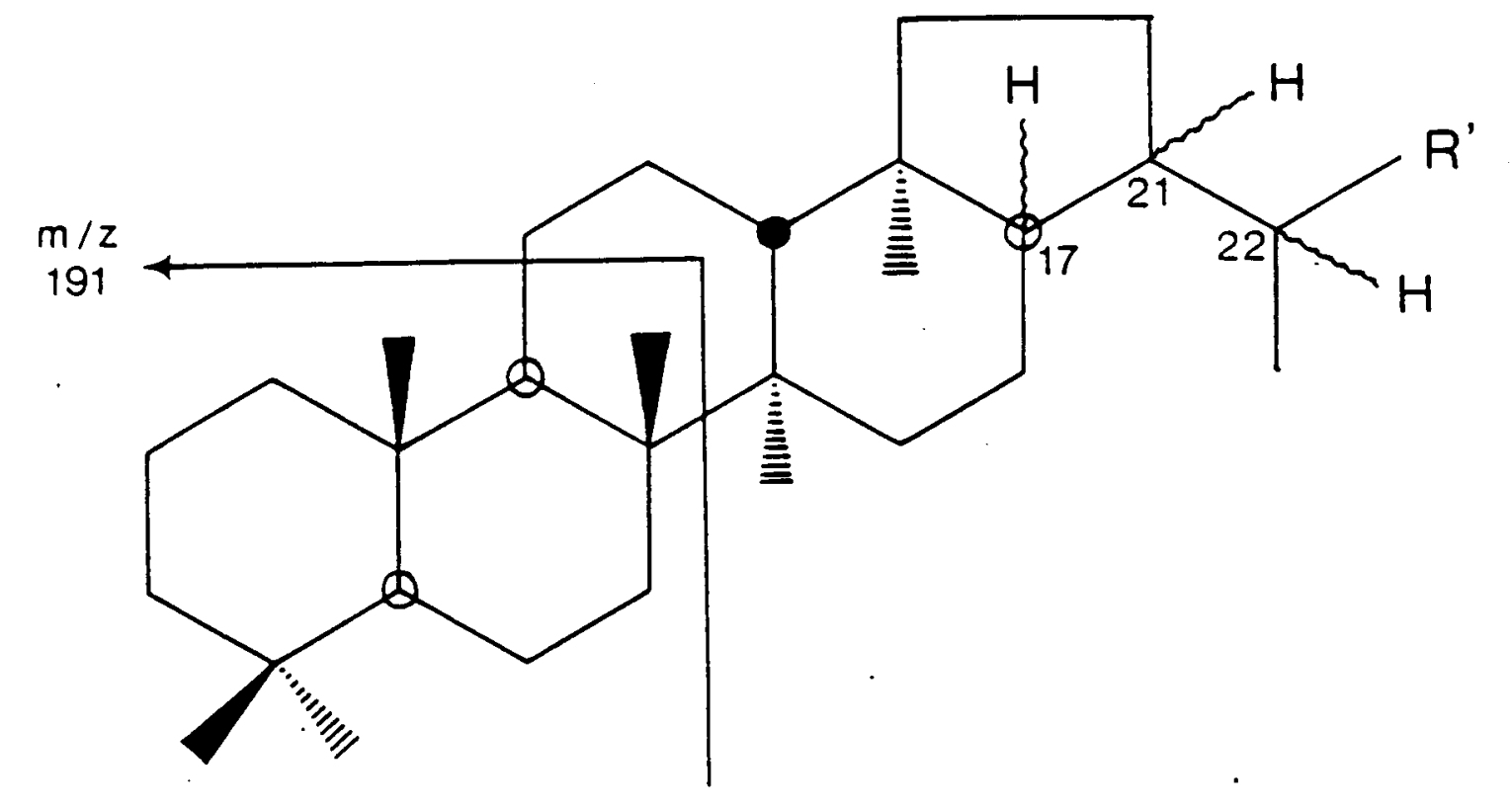

3. Fig. A-3: General hopane structure ( $c \geq 29$ ) with the key eragment $m / z=191$ of all hopanes indicated. $R^{\circ}$ means the alkyl side chain $R^{\prime}=C_{n} H_{2 n+1}$ or $R^{\circ}=\mathrm{H}$.

A solid/open dot represents a carbon-hydrogen bond pointing out/into the plane of paper. A solid/dotted triangle represents a carbon-carbon bond above/below the plane of paper and a sinuous line means that both the latter possibilities exist. 
stereoisomers have lightly different chemical and physical properties and can be distinguished in GC-MS by their different mass spectra and/or retention times. During sediment burial many of the biological stereoisomers become thermally unstable and adjust to more stable structures. These thermally induced changes in the stereochemistry of some biomarkers (e.g. hopanes, steranes, meso-pristane) can be quantified and used as maturity indices.

Selective ion monitoring was used for investigation of the biomarkers.

In this study most information was obtained from the GC-MS investigation of the hopane group (pentacyclic triterpenoids). The hopanes are one of the most abundant molecular groups of the biomarkers, reflecting their bacterial origin (Ourisson et al. 1979, 1984). Thus hopanes are found in almost all sediments (and petroleum) which are sufficient immature to have allowed preservation. All hopanes possess the same pentacyclic triterpenoid structure which only vary in the length of their alkyl side chains and stereochemistry: the molecular structure include possibilities for $\alpha$ or $B H$ atoms at $C-17$ and $C-21$ and $R$ or $S$ configuration at $C-22$. The key fragment $\mathrm{m} / \mathrm{z} 191$ of all hopanes is indicated in $\mathrm{fig}$. A-3.

It has been shown (Seifert \& Moldowan 1980) that the hopanes in living organisms and immature sediments are typically 17 $B H, 21 B H$ hopanes occurring as a single eplmer at C-22 (22R). The process of thermal maturation affects conversion to some $17 \mathrm{BH}, 21 \propto \mathrm{H}$ compounds (moretanes) but mainly $17 \propto \mathrm{H}, 21 \mathrm{BH}$ hopanes (which are more stable) while the $17 \mathrm{BH}, 21 \mathrm{BH}$ hopanes disappear (Ensminger \& Albrecht 1978). At higher levels of maturity the $17 \mathrm{BH}, 21 \mathrm{aH}$ moretanes are also converted into the thermodynamically most stable $17 \mathrm{aH}, 21 \mathrm{BH}$ configuration with the two C-22 diastereolsomeric pairs (22R and 22S) in the extended hopane members $\geq C_{31}$ (Seifert \& Moldowan 1980) (See 11g. A-4).

The epimerisation at the C-22 position takes place at a 


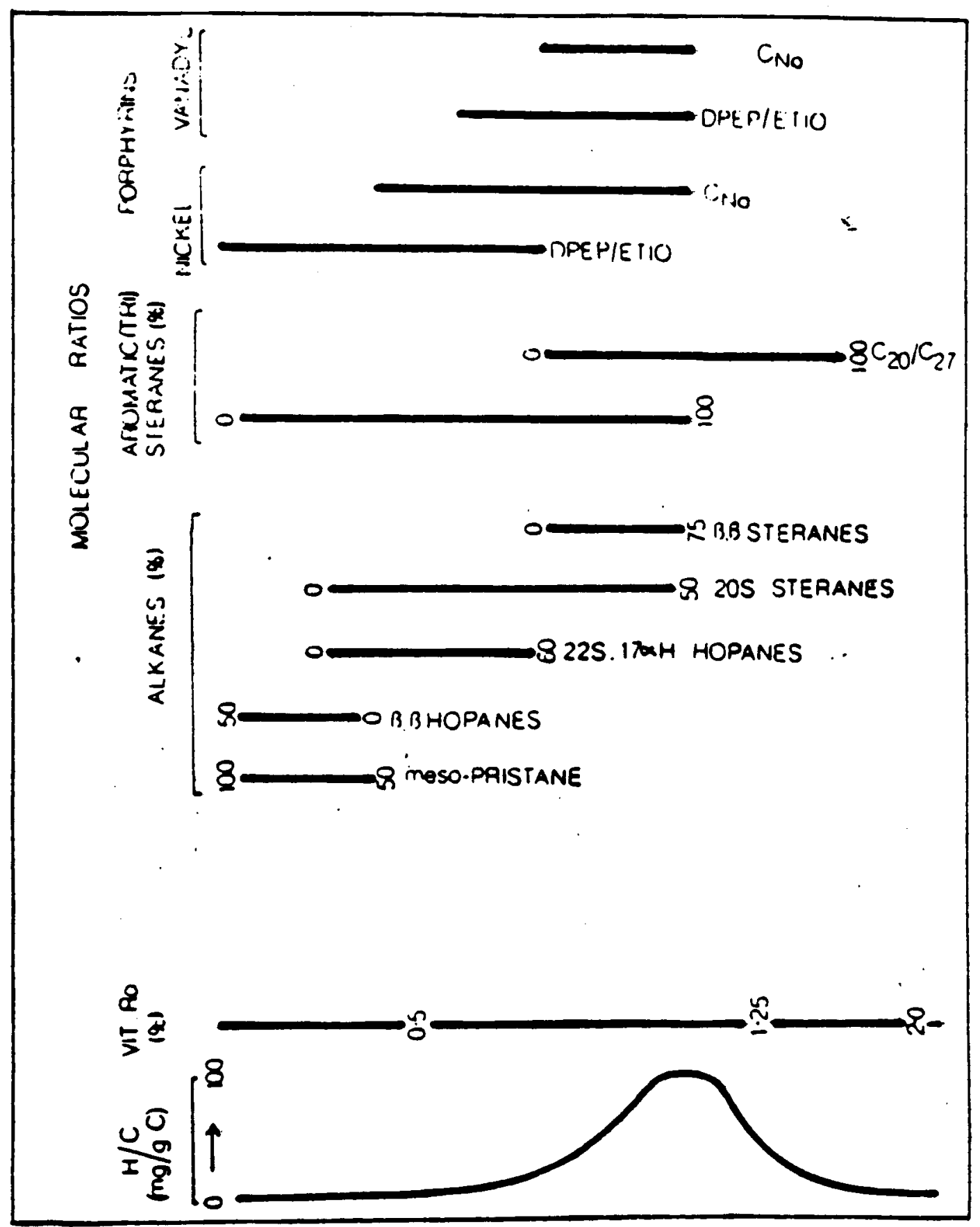

4. Fig. A-4: Ranges of individual molecular measurements for thermal maturation, plotted against the downhole hydrocarbon generation curve and vitrinite reflectance-values $\left(R_{0}\right)$. (Toarcian shale, Paris Basin and Pliensbachian shale, N.W. Germany). Reprinted from Mackenzie (1984), with permission. 
slower rate than conversions to $17 \mathrm{aH}, 21 \mathrm{BH}$ hopanes. The $22 \mathrm{~S}$ isomer is thermodynamically slightly more stable than the $22 R$ isomer and a final 60:40 mixture of $S$ and $R$ is achieved before the onset of intense hydrocarbon generation, as has been shown for the Paris Basin (Mackenzie \& Maxwell 1981). The hopane distributions in mature sediments and petroleum are thus characterized by high relative abundance of the stable $17 \alpha \mathrm{H}, 21 \mathrm{BH}$ configuration with mixtures of the C-22 isomers in members $\geq C_{31}$ (e.g. van Dorsselaer et al. 1974).

The ratio of the $\mathrm{C}-22$ diastereoisomers in the $17 \mathrm{aH}, 21 \mathrm{BH}$ hopane series was calculated by measuring the appropriate peak area for each component over the range $\mathrm{C}_{31}-\mathrm{C}_{34}$ in mass fragmentograms of $\mathrm{m} / \mathrm{z}$ 191. The ratio, expressed as an average of the ratios for each carbon number in the range (Mackenzie 1981), has been used as maturity index.

\section{Instruments}

The samples were analysed on a Varian 3700 gas chromatograph fitted with a quartz capillary column (20.m $\times 0.25 \mathrm{~mm}$ i.d.) with SE 54 as stationary phase. Helium was used as a carrier gas (head pressure 0.5 bar). The temperature was programmed from $100-300^{\circ} \mathrm{C}$ at $4^{\circ} \mathrm{C} / \mathrm{min}$ and held at $300^{\circ} \mathrm{C}$ for 15 minutes.

The gas chromatograph was interfaced directly (open interface) with a Finnigan Mat 8200 mass spectrometer (electron energy $70 \mathrm{eV}$, filament.current $1 \mathrm{~mA}$ ). The aquired data were registered in an Incos-system. The mass spectra were recorded cyclically with 1.1 sec. pr. scan. 
78

TABELS 
Table 1 Stratigraphy, lithology and total organic carbon (TOC)

\begin{tabular}{|c|c|c|c|c|c|c|c|}
\hline $\begin{array}{l}\text { Sample } \\
\text { no. }\end{array}$ & Lithostr: & ratigraphy & & & $\begin{array}{l}\text { Depth } \\
\text { below KB }\end{array}$ & $\begin{array}{l}\text { Main cutting } \\
\text { lithology }\end{array}$ & TOC \& \\
\hline $909 \mathrm{~A}$ & Vedsted & Formation & $(\mathrm{V}-4)$ & Mb.) & $4700^{\prime}$ & $\begin{array}{l}\text { light-medium } \\
\text { grey siltstone }\end{array}$ & 0.55 \\
\hline $910 \mathrm{~A}$ & - & - & -- & - & $4760^{\prime}$ & -- & 0.19 \\
\hline $911 \mathrm{~A}$ & - & - & $(V-3)$ & Mb.) & $4820^{\prime}$ & - & 0.48 \\
\hline $912 \mathrm{~A}$ & - & - & -- & - & $4880^{\prime}$ & $\begin{array}{l}\text { dark-grey-black } \\
\text { silty claystone }\end{array}$ & 1.06 \\
\hline $913 \mathrm{~A}$ & - & - & -- & - & $4940^{\prime}$ & -- & 1.19 \\
\hline $914 \mathrm{~A}$ & - & - & -- & - & $5000^{\prime}$ & $\begin{array}{l}\text { dark grey shaly } \\
\text { claystone }\end{array}$ & 1.33 \\
\hline $915 A$ & - & - & $(V-2)$ & Mb.) & $5060^{\prime}$ & - & 1.13 \\
\hline $916 \mathrm{~A}$ & - & - & -- & - & $5120^{\circ}$ & -- & 2.71 \\
\hline $917 A$ & - & - & $-\cdots$ & - & $5180^{\prime}$ & - & 1.01 \\
\hline $918 A$ & - & - & $(V-1)$ & Mb.) & $5240^{\prime}$ & - & 1.08 \\
\hline $919 A$ & - & - & $-\cdots$ & - & $5300^{\prime}$ & - & 1.33 \\
\hline $920 \mathrm{~A}$ & - & - & $-\cdots$ & - & $5360^{\circ}$ & - & 1.14 \\
\hline $921 \mathrm{~A}$ & - & - & $-\cdots$ & - & $5420^{\prime}$ &.- & 1.09 \\
\hline $922 \mathrm{~A}$ & - & - & $\because-$ & - & $5480^{\prime}$ & - & 0.88 \\
\hline $923 A$ & - & - & -- & - & $5540^{\prime}$ & $\begin{array}{l}\text { medium grey } \\
\text { claystone }\end{array}$ & 1.28 \\
\hline $924 \mathrm{~A}$ & Bream For & rmation $(F)$ & red. & Mb.) & $5600^{\prime}$ & -- & 1.19 \\
\hline $925 \mathrm{~A}$ & - & - & - & - & $5660^{\circ}$ & - & 0.92 \\
\hline $926 A$ & - & - & - & - & $5720^{\circ}$ & - & 0.75 \\
\hline $927 A$ & - & - & - & - & $5780^{\prime}$ & $\begin{array}{l}\text { brownish grey } \\
\text { silt/sandstone }\end{array}$ & 0.77 \\
\hline $928 \mathrm{~A}$ & - & - & - & - & $5840^{\circ}$ & - & 1.32 \\
\hline $929 A$ & - & - & - & - & $5900^{\prime}$ & - & 0.88 \\
\hline $930 \mathrm{~A}$ & - & - & - & - & $5960^{\prime}$ & - & 0.73 \\
\hline $931 \mathrm{~A}$ & - & - & - & - & $6020^{\circ}$ & $\begin{array}{l}\text { medium grey } \\
\text { silty claystone }\end{array}$ & 0.56 \\
\hline $932 A$ & - & (Be & $\operatorname{\phi rg} 1$. & . Mb.) & $6080^{\prime}$ & $\begin{array}{l}\text { medium grey } \\
\text { claystone }\end{array}$ & 0.80 \\
\hline $933 A$ & - & - & - & - & $6140^{\prime}$ & -- & 0.95 \\
\hline $934 \mathrm{~A}$ & - & - & - & - & $6200^{\prime}$ & -- & 1.16 \\
\hline $935 A$ & Haldager & Formation & (Flyo & $\begin{array}{l}\text { Mvbj. } \\
\text { Mb.) }\end{array}$ & $6250^{\prime}$ & $\begin{array}{l}\text { gray claystone } \\
\text { and light sand- } \\
\text { stone, coaly } \\
\text { particles }\end{array}$ & 0.86 \\
\hline
\end{tabular}


Table 1 Stratigraphy, lithology and total organic carbon (TOC) - continued

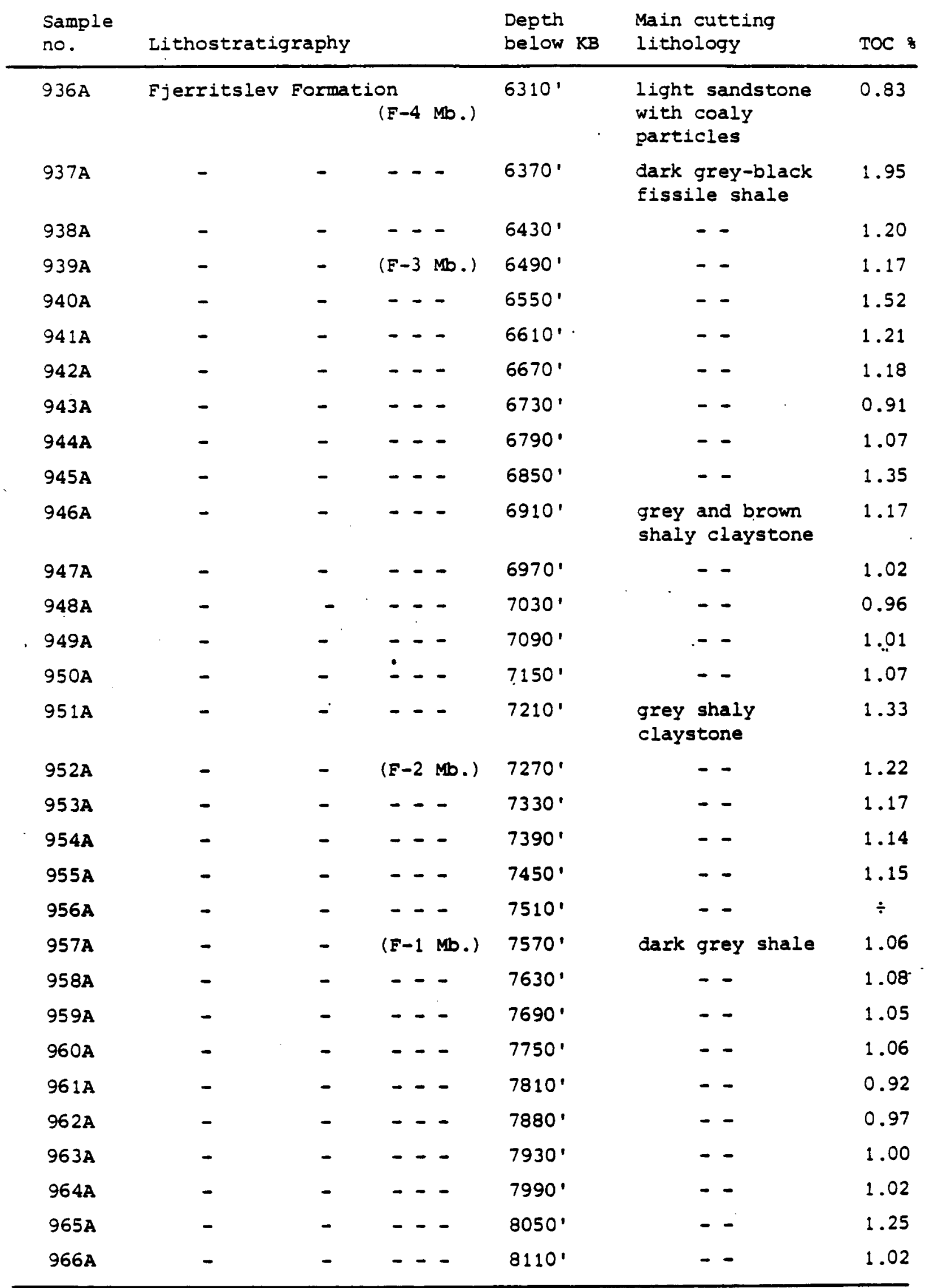


Table 1 Stratigraphy, lithology and total organic carbon (Toc) - continued

\begin{tabular}{|c|c|c|c|c|c|c|c|c|}
\hline $\begin{array}{l}\text { Sample } \\
\text { no. }\end{array}$ & Lithostr & ratig & Iraphy & & & $\begin{array}{l}\text { Depth } \\
\text { below KB }\end{array}$ & $\begin{array}{l}\text { Main cutting } \\
\text { lithology }\end{array}$ & TOC 8 \\
\hline $967 \mathrm{~A}$ & Fjerrits & slev & Format & on & Mb.) & $8170^{\prime}$ & $\begin{array}{l}\text { dark grey shale } \\
\text { with some coarse } \\
\text { quartz grains }\end{array}$ & 1.13 \\
\hline $968 A$ & - & & - & - & - & $8230^{\prime}$ & $\begin{array}{l}\text { dark grey shale } \\
\text { with some coarse } \\
\text { quartz grains and } \\
\text { dark fine laminated } \\
\text { sand/siltstone with } \\
\text { coaly stringers }\end{array}$ & d \\
\hline $969 A$ & - & & - & - & - & $8290^{\prime}$ & - & 0.85 \\
\hline $970 \mathrm{~A}$ & - & & - & - & - & $8350^{\prime}$ & $\begin{array}{l}\text { dark laminated } \\
\text { sand/siltstone } \\
\text { with coaly stringer } \\
\text { and dark shale }\end{array}$ & $\begin{array}{l}0.89 \\
65\end{array}$ \\
\hline $971 A$ & - & & - & - & - & $8410^{\prime}$ & - & 0.89 \\
\hline $972 \mathrm{~A}$ & Gassum E & Format & tion & & & $8470^{\prime}$ & - & 1.01 \\
\hline $973 \mathrm{~A}$ & - & - & & & & $8530^{\prime}$ & $\begin{array}{l}\text { grey shale, coarse } \\
\text { grained sandstone } \\
\text { with coaly particles }\end{array}$ & $\begin{array}{l}1.22 \\
\text { es }\end{array}$ \\
\hline $974 A$ & - & - & & & & $8590^{\prime}$ & $\cdot \quad-\quad$ & 1.09 \\
\hline $975 A$ & - & $\dot{-}$ & & & & $8650^{\prime}$ & $\begin{array}{l}\text { - - besides some } \\
\text { carbonate cutting }\end{array}$ & 0.92 \\
\hline $976 A$ & - & - & & & & $8710^{\prime}$ & $\begin{array}{l}\text { dark grey shale } \\
\text { and yellowish fine } \\
\text { grained sandstone } \\
\text { with coaly particle }\end{array}$ & $\begin{array}{l}1.11 \\
25\end{array}$ \\
\hline $977 \mathrm{~A}$ & - & - & & & & $8770^{\prime}$ & -- & 0.98 \\
\hline $978 A$ & - & - & & & & $8830^{\prime}$ & $\begin{array}{l}\text { light sandstone, } \\
\text { red-green mottled } \\
\text { claystone, } \\
\text { dark claystone }\end{array}$ & 0.71 \\
\hline $979 A$ & - & - & & & & $8890^{\prime}$ & -- & 0.55 \\
\hline $980 \mathrm{~A}$ & - & - & & & & $8950^{\prime}$ & $\begin{array}{l}\text { light coarse } \\
\text { grained sand and } \\
\text { siltstone, dark } \\
\text { shale, some mottled } \\
\text { red-green claystone }\end{array}$ & 0.42 \\
\hline $981 \mathrm{~A}$ & - & - & & & & $9020^{\prime}$ & -- & 0.68 \\
\hline $982 \mathrm{~A}$ & Vinding & Forma & ation & & & $9080^{\prime}$ & $\begin{array}{l}\text { dark shale, some } \\
\text { sand/siltstone } \\
\text { with coaly } \\
\text { stringers, } \\
\text { carbonates }\end{array}$ & 0.82 \\
\hline
\end{tabular}


Table 1 Stratigraphy, lithology and total organic carbon (TOC) - continued

\begin{tabular}{|c|c|c|c|c|}
\hline $\begin{array}{l}\text { Sample } \\
\text { no. }\end{array}$ & Lithostratigraphy & $\begin{array}{l}\text { Depth } \\
\text { below KB }\end{array}$ & $\begin{array}{l}\text { Main cutting } \\
\text { lithology }\end{array}$ & TOC \& \\
\hline $983 A$ & Vinding Formation & $9140^{\prime}$ & $\begin{array}{l}\text { dark grey and } \\
\text { brownish shale, } \\
\text { dark mottled } \\
\text { carbonates }\end{array}$ & 0.73 \\
\hline $984 \mathrm{~A}$ & - & $9200^{\prime}$ & - & 0.75 \\
\hline $985 A$ & - & $9260^{\prime}$ & $\begin{array}{l}\text { dark grey-black } \\
\text { brownish shale, } \\
\text { dark mottled } \\
\text { carbonates }\end{array}$ & 0.56 \\
\hline $986 \mathrm{~A}$ & - & $9320^{\prime}$ & - & 0.76 \\
\hline $987 A$ & Oddesund Formation & $9380^{\prime}$ & $\begin{array}{l}\text { light grey clay- } \\
\text { stone and silt- } \\
\text { stone, } \\
\text { few carbonates }\end{array}$ & 0.70 \\
\hline $988 A$ & - & $9440^{\prime}$ & -- & 0.54 \\
\hline $989 A$ & - & $9460^{\prime}$ & - & 0.67 \\
\hline
\end{tabular}


Table 2 Vitrinite reflectance measurements

\begin{tabular}{|c|c|c|c|}
\hline $\begin{array}{l}\text { Sample } \\
\text { no. }\end{array}$ & $\begin{array}{l}\text { Depth } \\
\text { below KB }\end{array}$ & $\& \bar{R}_{0}$ & $\begin{array}{l}\text { Number of } \\
\text { measurements }\end{array}$ \\
\hline $909 A$ & $4700^{\circ}$ & 0.45 & 18 \\
\hline $910 \mathrm{~A}$ & $4760^{\prime}$ & 0.48 & 9 \\
\hline $911 \mathrm{~A}$ & $4820^{\prime}$ & 0.44 & 31 \\
\hline $912 \mathrm{~A}$ & $4880^{\circ}$ & 0.46 & 49 \\
\hline $913 \mathrm{~A}$ & $4940^{\prime}$ & 0.45 & 56 \\
\hline $914 \mathrm{~A}$ & $5000^{\prime}$ & 0.45 & 32 \\
\hline $915 \mathrm{~A}$ & $5060^{\circ}$ & 0.47 & 19 \\
\hline $916 \mathrm{~A}$ & $5120^{\prime}$ & 0.48 & 44 \\
\hline $917 \mathrm{~A}$ & $5180^{\prime}$ & 0.46 & 11 \\
\hline $918 \mathrm{~A}$ & $5240^{\prime}$ & 0.47 & 9 \\
\hline $919 A$ & $5300^{\circ}$ & 0.45 & 14 \\
\hline $920 \mathrm{~A}$ & $5360^{\prime}$ & 0.46 & 16 \\
\hline $921 \mathrm{~A}$ & $5420^{\prime}$ & 0.47 & 11 \\
\hline $922 \mathrm{~A}$ & $5480^{\circ}$ & 0.45 & 16 \\
\hline $923 \mathrm{~A}$ & $5540^{\prime}$ & 0.46 & 26 \\
\hline $924 \mathrm{~A}$ & $5600^{\circ}$ & 0.47 & 17 \\
\hline 925A & $5660^{\circ}$ & 0.47 & 13 \\
\hline $926 \mathrm{~A}$ & $5720^{\prime}$ & 0.48 & 20 \\
\hline $927 A$ & $5780^{\prime}$ & 0.42 & 16 \\
\hline $928 \mathrm{~A}$ & $5840^{\prime}$ & 0.47 & 20 \\
\hline $929 \mathrm{~A}$ & $5900^{\prime}$ & 0.44 & 25 \\
\hline $930 \mathrm{~A}$ & $5960^{\prime}$ & 0.45 & 17 \\
\hline $931 \mathrm{~A}$ & $6020^{\prime}$ & 0.47 & 28 \\
\hline $932 \mathrm{~A}$ & $6080^{\prime}$ & 0.46 & 19 \\
\hline $933 \mathrm{~A}$ & $6140^{\prime}$ & 0.50 & 33 \\
\hline $934 A$ & $6200^{\prime}$ & 0.50 & 27 \\
\hline $935 \mathrm{~A}$ & $6250^{\prime}$ & 0.50 & 37 \\
\hline $936 \mathrm{~A}$ & $6310^{\circ}$ & 0.49 & 78 \\
\hline $937 \mathrm{~A}$ & $6370^{\circ}$ & 0.49 & 55 \\
\hline $938 A$ & $6430^{\prime}$ & 0.49 & 46 \\
\hline $939 A$ & $6490^{\circ}$ & 0.49 & 47 \\
\hline $940 \mathrm{~A}$ & $6550^{\prime}$ & 0.50 & 35 \\
\hline $941 \mathrm{~A}$ & $6610^{\prime}$ & 0.52 & 23 \\
\hline $942 \mathrm{~A}$ & $6670^{\circ}$ & 0.48 & 29 \\
\hline $943 A$ & $6730^{\prime}$ & 0.51 & 46 \\
\hline
\end{tabular}


Table 2 Vitrinite reflectance measurements - continued

\begin{tabular}{|c|c|c|c|}
\hline $\begin{array}{l}\text { Sample } \\
\text { no. }\end{array}$ & $\begin{array}{l}\text { Depth } \\
\text { below KB }\end{array}$ & $\bar{R}_{0}$ & $\begin{array}{l}\text { Number of } \\
\text { measurements }\end{array}$ \\
\hline $944 \mathrm{~A}$ & $6790^{\circ}$ & 0.48 & 27 \\
\hline $945 A$ & $6850^{\prime}$ & 0.51 & 37 \\
\hline $946 \mathrm{~A}$ & $6910^{\prime}$ & 0.51 & 25 \\
\hline $947 \mathrm{~A}$ & $6970^{\circ}$ & 0.50 & 17 \\
\hline $948 \mathrm{~A}$ & $7030^{\prime}$ & 0.53 & 56 \\
\hline $949 \mathrm{~A}$ & $7090^{\circ}$ & 0.54 & 58 \\
\hline $950 \mathrm{~A}$ & $7150^{\circ}$ & 0.53 & 30 \\
\hline $951 \mathrm{~A}$ & $7210^{\circ}$ & 0.54 & 42 \\
\hline $952 \mathrm{~A}$ & $7270^{\prime}$ & 0.52 & 54 \\
\hline $953 \mathrm{~A}$ & $7330^{\circ}$ & 0.54 & 52 \\
\hline $954 \mathrm{~A}$ & $7390^{\prime}$ & 0.54 & 68 \\
\hline $955 \mathrm{~A}$ & $7450^{\circ}$ & 0.54 & 36 \\
\hline $956 \mathrm{~A}$ & $7510^{\circ}$ & 0.55 & 44 \\
\hline $957 \mathrm{~A}$ & $7570^{\circ}$ & 0.56 & 24 \\
\hline $958 A$ & $7630^{\circ}$ & 0.57 & 12 \\
\hline $959 \mathrm{~A}$ & $7690^{\prime}$ & 0.57 & 37 \\
\hline $960 \mathrm{~A}$ & $7750^{\circ}$ & 0.56 & 37 \\
\hline $961 \mathrm{~A}$ & $7810^{\circ}$ & 0.58 & 47 \\
\hline $962 A$ & $7870^{\circ}$ & 0.58 & 56 \\
\hline $963 A$ & $7930^{\circ}$ & 0.58 & 62 \\
\hline $964 A$ & '7990' & 0.60 & 54 \\
\hline $965 A$ & $8050^{\prime}$ & 0.55 & 82 \\
\hline $966 A$ & $8110^{\circ}$ & 0.57 & 56 \\
\hline $967 A$ & $8170^{\circ}$ & 0.57 & 31 \\
\hline $968 A$ & $8230^{\circ}$ & 0.61 & 27 \\
\hline 969A & $8290^{\circ}$ & 0.59 & 49 \\
\hline 970A & $8350^{\circ}$ & 0.60 & 62 \\
\hline $971 \mathrm{~A}$ & $8410^{\circ}$ & 0.60 & 63 \\
\hline $972 A$ & $8470^{\prime}$ & 0.63 & 46 \\
\hline $973 A$ & $8530^{\circ}$ & 0.63 & 81 \\
\hline $974 A$ & $8590^{\circ}$ & 0.62 & 21 \\
\hline $975 A$ & $8650^{\prime}$ & 0.62 & 74 \\
\hline $976 \mathrm{~A}$ & $8710^{\circ}$ & 0.63 & 65 \\
\hline $977 A$ & $8770^{\circ}$ & 0.62 & 53 \\
\hline $978 A$ & $8830^{\prime}$ & 0.63 & 20 \\
\hline
\end{tabular}


Table 2 Vitrinite reflectance measurements - continued

\begin{tabular}{llll}
$\begin{array}{l}\text { Sample } \\
\text { no. }\end{array}$ & $\begin{array}{l}\text { Depth } \\
\text { below KB }\end{array}$ & $\overrightarrow{\mathrm{R}}_{0}$ & $\begin{array}{l}\text { Number of } \\
\text { measurements }\end{array}$ \\
\hline $979 \mathrm{~A}$ & $8890^{\circ}$ & 0.62 & 23 \\
$980 \mathrm{~A}$ & $8950^{\circ}$ & 0.67 & 33 \\
$981 \mathrm{~A}$ & $9020^{\circ}$ & 0.62 & 45 \\
$982 \mathrm{~A}$ & $9080^{\circ}$ & 0.63 & 66 \\
$983 \mathrm{~A}$ & $9140^{\circ}$ & $\div$ & $\div$ \\
$984 \mathrm{~A}$ & $920^{\circ}$ & 0.63 & 16 \\
$985 \mathrm{~A}$ & $9260^{\circ}$ & 0.67 & 33 \\
$986 \mathrm{~A}$ & $9320^{\circ}$ & $\div$ & $\div$ \\
$987 \mathrm{~A}$ & $9380^{\circ}$ & 0.62 & 27 \\
$988 \mathrm{~A}$ & $9440^{\circ}$ & 0.64 & 18 \\
$989 \mathrm{~A}$ & $9460^{\circ}$ & 0.66 & 41 \\
\hline
\end{tabular}


Table 3 Data of spectral fluorescence measurements on the organic extracts and corresponding reflectance values.

\begin{tabular}{|c|c|c|c|c|c|}
\hline $\begin{array}{l}\text { Sample } \\
\text { no. }\end{array}$ & $\begin{array}{c}\text { red/green } \\
\text { ratio } \\
\text { (Q-value) }\end{array}$ & $\lambda_{\max }$ & $\begin{array}{l}\text { trichromatic } \\
\mathbf{x}\end{array}$ & $\begin{array}{c}\text { coordinates } \\
y\end{array}$ & $\overline{\mathbf{R}}_{0}$ \\
\hline $913 \mathrm{~A}$ & 0.86 & 565 & 0.3694 & 0.4424 & 0.45 \\
\hline $915 \mathrm{~A}$ & 0.44 & 540 & 0.3161 & 0.4192 & 0.47 \\
\hline $916 \mathrm{~A}$ & 0.53 & 505 & 0.3019 & 0.3739 & 0.48 \\
\hline $923 \mathrm{~A}$ & 0.31 & 520 & 0.2853 & 0.3858 & 0.46 \\
\hline $929 A$ & 0.52 & 545 & 0.3318 & 0.4318 & 0.44 \\
\hline $932 \mathrm{~A}$ & 0.66 & 550 & 0.3526 & 0.4461 & 0.46 \\
\hline 936A & 0.67 & 545 & 0.3449 & 0.4325 & 0.49 \\
\hline $937 A$ & 1.20 & 580 & 0.3861 & 0.4378 & 0.49 \\
\hline 938A & 1.06 & 570 & 0.3797 & 0.4390 & 0.49 \\
\hline 940A & 1.22 & 575 & 0.3911 & 0.4460 & 0.50 \\
\hline $945 A$ & 1.46 & 580 & 0.4090 & 0.4548 & 0.51 \\
\hline 954A & 1.66 & 590 & 0.4203 & 0.4565 & 0.54 \\
\hline $957 \mathrm{~A}$ & 0.99 & 565 & 0.3861 & 0.4641 & 0.56 \\
\hline $959 A$ & 1.03 &. .575 & 0.3910 & 0.4645 & 0.57 \\
\hline $967 A$ & 1.23 & 580 & 0.4010 & 0.4624 & 0.57 \\
\hline $973 A$ & 1.73 & 590 & 0.4241 & 0.4629 & 0.63 \\
\hline 976A & 1.44 & 585 & 0.4092 & 0.4587 & 0.63 \\
\hline $982 \mathrm{~A}$ & 1.06 & 575 & 0.3864 & 0.4491 & 0.63 \\
\hline $985 A$ & 1.14 & 570 & 0.3994 & 0.4666 & 0.67 \\
\hline
\end{tabular}




\begin{tabular}{|c|c|c|c|c|c|c|c|c|}
\hline $\begin{array}{l}\text { Sample } \\
\text { no. }\end{array}$ & $\begin{array}{l}\text { Sediment } \\
\text { extracted }(g)\end{array}$ & $\begin{array}{l}\text { EOM } \\
\text { ppm }\end{array}$ & $\begin{array}{l}\text { mg EOM } \\
\text { /g TOC }\end{array}$ & $\begin{array}{l}\mathrm{mg} \text { HC } \\
/ \mathrm{g} \text { TOC }\end{array}$ & $\begin{array}{c}\text { sat } H C \\
8\end{array}$ & $\underset{8}{\operatorname{arom} \mathrm{HC}}$ & $\begin{array}{l}\text { total } \mathrm{HC} \\
\mathrm{q}\end{array}$ & $\begin{array}{c}\text { non } \mathrm{HC} \\
8\end{array}$ \\
\hline $913 \mathrm{~A}$ & 47.21 & 180 & 15.1 & 6.6 & 19 & 25 & 44 & 56 \\
\hline $915 A$ & 55.37 & 220 & 19.5 & 9.4 & 24 & 24 & 48 & 52 \\
\hline $916 \mathrm{~A}$ & 59.32 & 912 & 33.7 & 9.1 & 7 & 20 & 27 & 73 \\
\hline $923 A$ & 49.87 & 900 & 70.3 & 41.5 & 34 & 25 & 59 & 41 \\
\hline $929 A$ & 41.22 & 197 & 22.3 & 5.8 & 15 & 11 & 26 & 74 \\
\hline $932 \mathrm{~A}$ & 39.05 & 213 & 26.6 & 11.4 & 27 & 16 & 43 & 57 \\
\hline $936 \mathrm{~A}$ & 49.52 & 214 & 25.8 & 15.2 & 26 & 33 & 59 & 41 \\
\hline $937 \mathrm{~A}$ & 22.34 & 663 & 34.0 & 12.6 & 16 & 21 & 37 & 63 \\
\hline 938A & 39.62 & 558 & 46.5 & 8.8 & 7 & 12 & 19 & 81 \\
\hline $940 A$ & 46.58 & 554 & 36.4 & 16.0 & 22 & 22 & 44 & 56 \\
\hline $945 A$ & 44.31 & 413 & 30.6 & 6.7 & 4 & 18 & 22 & 78 \\
\hline $954 \mathrm{~A}$ & 51.06 & 313 & 27.5 & 11.0 & 10 & 30 & 40 & 60 \\
\hline $957 \mathrm{~A}$ & 48.97 & 292 & 27.5 & 13.8 & 15 & 35 & 50 & 50 \\
\hline $959 A$ & 54.84 & 254 & 24.1 & 7.2 & 13 & 17 & 30 & 70 \\
\hline $967 A$ & 44.30 & 348 & 30.8 & 14.8 & 16 & 32 & 48 & 52 \\
\hline $973 A$ & 46.89 & 346 & 28.3 & 10.2 & 7 & 29 & 36 & 64 \\
\hline $976 \mathrm{~A}$ & 43.47 & 368 & 33.2 & 11.6 & 9 & 26 & 35 & 65 \\
\hline $982 A$ & 51.96 & 579 & 70.6 & 28.9 & 22 & 19 & 41 & 59 \\
\hline $985 A$ & 49.79 & 593 & 105.8 & 60.3 & 45 & 12 & 57 & 43 \\
\hline
\end{tabular}

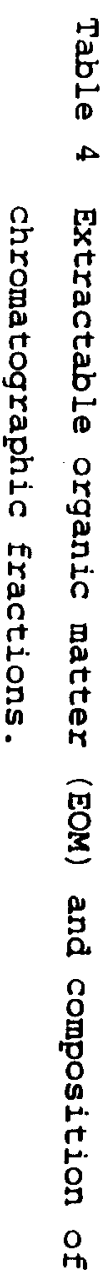


Table 5 Ratios determined by gas chromatographic analysis.

\begin{tabular}{lllll} 
Sample no. & pri/n-C 17 & phy/n-C 18 & pri/phy & CPI $\left(C_{23}-C_{29}\right)$ \\
\hline $913 \mathrm{~A}$ & 0.86 & 0.44 & 1.13 & - \\
$915 \mathrm{~A}$ & 1.28 & 0.80 & 1.62 & - \\
$916 \mathrm{~A}$ & 3.43 & 2.65 & 0.98 & - \\
$923 \mathrm{~A}$ & 1.40 & 0.38 & 1.17 & - \\
$929 \mathrm{~A}$ & 1.41 & 0.55 & 2.00 & - \\
$932 \mathrm{~A}$ & 1.40 & 0.75 & 1.31 & - \\
$936 \mathrm{~A}$ & 1.33 & 0.61 & 1.71 & - \\
$937 \mathrm{~A}$ & 1.61 & 0.93 & 1.30 & 1.54 \\
$938 \mathrm{~A}$ & 1.54 & 1.01 & 1.32 & 1.79 \\
$940 \mathrm{~A}$ & 1.62 & 1.10 & 1.58 & 1.53 \\
$945 \mathrm{~A}$ & 1.78 & 1.06 & 1.56 & 1.64 \\
$954 \mathrm{~A}$ & 1.42 & 0.74 & 1.62 & - \\
$957 \mathrm{~A}$ & 1.32 & 0.56 & 2.34 & 1.48 \\
$959 \mathrm{~A}$ & 0.99 & 0.58 & 1.54 & 1.60 \\
$967 \mathrm{~A}$ & 0.89 & 0.75 & 1.15 & - \\
$973 \mathrm{~A}$ & 1.22 & 0.72 & 1.24 & 1.36 \\
$976 \mathrm{~A}$ & 0.87 & 0.62 & 1.36 & - \\
$982 \mathrm{~A}$ & 1.14 & 0.83 & 1.55 & 1.16 \\
$985 \mathrm{~A}$ & 0.91 & 0.54 & 1.54 & 1.08 \\
\hline
\end{tabular}


Table 6 Average diastereoisomer ratio of the $C_{31}-C_{34} 17 \alpha(H) 21 \beta(H)$-hopanes and relative content of the $17 B(\mathrm{H}) 21 B(\mathrm{~B})$-hopanes.

\begin{tabular}{llcc} 
Sample & $\begin{array}{l}\text { Depth } \\
\text { below KB }\end{array}$ & $\sum 22 \mathrm{~S}(\alpha \beta) / \sum 22 \mathrm{~S}+22 \mathrm{R}(\alpha \beta)$ & $\beta B$ \\
\hline $913 \mathrm{~A}$ & $4940^{\circ}$ & $(0.37)^{\dagger}$ & +++ \\
$915 \mathrm{~A}$ & $5060^{\circ}$ & $0.30^{+}$ & +++ \\
$916 \mathrm{~A}$ & $5120^{\circ}$ & $(0.45)^{\circ}$ & ++ \\
$932 \mathrm{~A}$ & $6080^{\circ}$ & $(-)^{+}$ & + \\
$940 \mathrm{~A}$ & $6550^{\circ}$ & $0.33^{+}$ & + \\
$959 \mathrm{~A}$ & $7690^{\circ}$ & 0.50 & - \\
$967 \mathrm{~A}$ & $8170^{\circ}$ & $0.59^{\circ}$ & - \\
$973 \mathrm{~A}$ & $8530^{\circ}$ & 0.56 & - \\
$982 \mathrm{~A}$ & $9080^{\circ}$ & 0.56 & - \\
$985 \mathrm{~A}$ & $9260^{\circ}$ & 0.55 & + \\
\hline
\end{tabular}

' : only estimated in the range $c_{31}-c_{32}$

( ) : low concentrations 
Table 7 Microscopic description of the cuttings and composition of the organic matter

909A $4700^{\circ}$ Vedsted Formation (V-4 Member)

Light-medium grey siltstone, glauconite very frequent (some chalk-cavings).

The sample has a moderate-low organic content of fine grained particles, dominated by pseudovitrinite and only a few small true huminite/vitrinite particles for reflectance measurements. Very few wisps of liptinite and inertinite. Pseudovitrinite particles often look reworked: high reflecting rounded particles with oxidation rims and shrinkage cracks. Blue light induces a weak brownish-orange fluorescence from few sporinite and few liptodetrinites.

$4760^{\circ}$ Ved sted Formation (V-4 Member)

Like 909A, but difflcult to estimate because of extensive contamination (cavings and additives) many chalk cavings.

$911 \mathrm{~A} 4820^{\circ}$ Vedsted Formation (V-3 Member)

Like $909 \mathrm{~A}$

912A $4880^{\circ}$ Vedsted Formation (V-3 Member).

Dark grey-black silty claystone, large content of small pyrite framboids, glauconite very rare.

The sample shows a moderate content of organic matter, most pseudovitrinite and large angular huminitelvitrinite particles (often ulminites with cellular structure), few liptinites.

Blue light induces dark orange fluorescence from fow sporinite and liptodetrinite, low liptinite content.

$4940^{\circ}$ Vedsted Format Ion (V-3 Member)

Like $912 \AA$, but sone contanination.

$91415000^{\circ}$ Vedsted Formation (V-3 Member)

Dark grey shaly claystone, often pyrite frambolds, some glauconite. The sample has a moderate content of organic matter, most pseudovitrinite (some show oxidation rims and shrinkage cracks) together with liptinite, only fow small huminite/vitrinite particles.

In blue light some alginite (dinoflagellates) are seen with yellow fluorescence, faw sporinite (yellow-orange (luorescence), but most liptodetrinites (dark orange fluorescence); moderate liptinlte content. 
$5120^{\circ}$ Vedsted Formation (V-2 Memoer)

Dark grey shaly claystone (some chalk-cuttings), glauconite is rare, but small pyrite framboids are very frequent.

The sample has a very high content of fine grained organic matter, most consisting of liptinite and smaller amounts of pseudovitrinite and huminitel vitrinite, but relatively high content of inertinite particles (tiny fusinite fragments and some micrinite). True huminite/vitrinite particles are small and angular, some of them are relatively weak reflecting types.

In blue light a high liptinite content is seen, most as many fine stringers of bituminite with dull orange fluorescing inclusions, besides some small liptodetrinites. Few greenish-yellow fluorescing alginites (dinoflagellates).

$5180^{\circ}$ Vedsted Eormation ( $V-2$ Member)

Dark grey shaly claystone, pyrite and glauconite occur.

The sample has a moderate content of organic matter with approximately equal amounts of pseudovitrinite (many reworked) and liptinite, tew wisps of huminite/vitrinite and rare inertinite.

In blue light some alginite (dinoplagellates) arcritarchs) are seen with yellow pluorescence, some fow sporinites and moderate liptinite content.

218A $5240^{\circ}$ Vedsted Foraation ( $V-1$ Member) Like 917 A.

$219 \mathrm{~A} 5300^{\circ}$ Vedsted Formation (V-1 Member)

Like $917 \mathrm{~A}$, besides a fow stringers of bituminite.

220A $5360^{\circ}$ Vedsted Formation ( $V-1$ Member)

Like 919 .

$921 \mathrm{~A} 5420^{\circ}$ Vedsted Formation ( $\mathrm{V}-1$ Member)

Like $919 A$.

$922 \mathrm{~A} 5480^{\circ}$ Vedsted Formation (V-1 Member) Like $919 A$.

223A $5540^{\circ}$ Vedsted Formation ( $\mathrm{V}-1$ Member)

Medium grey claystone, with a large content of pyrite, glauconite occurs.

The sample has a verying (low-hlgh) content or organic matter, only a few cuttings show a high content of very line grained particles, mostly liptinite and pseudovitrinite, less huminite/vitrinite.

In blue light in a few cuttings many very small and some larger liptodetrinites are seen together with some alginite (dinollagellates with greenish-yellow fluorescence) and fow sporinites (yellow fluorescence), few bituminite stringers. 
$224 \mathrm{~A} 5600^{\circ}$ Bream Formation (Frederikshavn Member)

Like 923A, but some less liptinite and less organic matter.

925A $5660^{\circ}$ Bream Formation (Frederikshavn Member) Like $924 \mathrm{~A}$.

926A $5720^{\circ}$ Bream Formation (Froderikshavn Member) Like $924 \mathrm{~A}$.

$927 \mathrm{~A} 5780^{\circ}$ Bream Formation (Frederikshavn Member) Brownish grey silt/sandstone, very rich in glauconite, some pyrite.

The sample has a moderate-low content of relatively coarse grained organic atter, most liptinite and less pseudovitrinite. Very few huminite/vitrinite (some lower reflecting types) and inertinite.

In blue light some large structured liptodetrinites are seen together with some alginite (dinoflagellates, greenish-yellow (luorescence) and sporinite, few streaks of bituminite are also seen.

$928 \mathrm{~A} \quad 5840^{\circ}$ Bream Formation (Froderikshavn Member) like 927 , but with a higher organic content.

$5900^{\circ}$ Bream Formation (Frederiskhava Member)

Brownish grey silt/sandstone, $r i c h$ in glauconite in the coarser cuttings, erequently pyrite.

The sample has a moderate content of organic matter, higher in the wore coarse grained cuttings. Especially in the coarse grained parts liptinite is dominant, some pseudovitrinite and inertinite fragments (Pusinite and sclerotinite), a few huminite/vitrinite.

In blue light much liptinite is seen as large detrinites (and some dinoplagellates) with yellow Pluorescence and stringers of bituminite, a fow recognizable alginite and sporinite, resinite obserred.

$23045960^{\circ}$ Brean Forwation (Frederikshavn Menber)

Like 929A, but lower organic content and wany small llptodetrinites.

$231 \mathrm{~A} 6020^{\circ}$ Brean Formation (Frederikshavn Member)

Medium grey silty claystone, pyrite and glauconite occur.

The sample has a moderate-low content of organic matter, like In $929 k$ and $930 \mathrm{~A}$ malnly consisting of liptinite and only small amounts of pseudovitrinite and huminite/vitrinite.

In blue light the liptinite (yellow-orange pluorescence) is mainly seen as very small tiny detrinites (5 5 a) af alginites together with a fow recognizable alginites (dinoplagellates) and sporinites. 
$6080^{\circ}$ Bream Formation (Borglum Member)

Medium grey claystone with pyrite and glauconite.

The sample has a moderate content of organic matter with a composition like $931 \mathrm{~A}$, besides some stringers of bltuminite.

933A $6140^{\circ}$ Bream Formation (Borglum Member)

Like $932 \mathrm{~A}$.

$934 \mathrm{~A} 6200^{\circ}$ Bream Formation (Børglum Member)

Like $932 \mathrm{~A}$.

$6250^{\circ}$ Haldager Formation (FIyvojerg Member)

Grey claystone and light sandstone, coaly particles and mica, pyrite occurs, glauconite very rare.

The sample has a moderate content of organtc matter, but somewhat varying amount and composition. Approximately equal proportions of liptinite and pseudovitinite together with some particles of huminite/vitrinite and a fow inertinites.

In blue light the liptinite (yellow-orange eluorescence) especially is seen as tiny liptodetrinites and sporinites, som bituminite (cutinite observed).

$6310^{\circ}$ Fjerritsiev Formation (F-4 Member)

Light sandstone with coaly particles and mica, pyrite frambolds, glauconite absent.

The sample has a moderate content of organic matter, about equal amounts of liptinite and pseudovitrinite -and huminite/vitrinite. Many small angular partic̈les of pseudovitrinite and huminite/vitrinite occur, but a Cow large (up to $1 \mathrm{~mm}$ ) huminite/vitrinite particles (sometimes with cellular structure) $936 \mathrm{~A}$ cont.

also occur. Here also sowe fow inertinites (Pusinites and sclerotinites) are seen.

Blue light shows a moderate liptinite content. Orange fluorescence from som streaky liptodetrivites and sporinite and orange-brown bituminite. Alginite and ?cutinite are observed.

$23746370^{\circ}$ Fjerritsiev Formation (F-4 Member)

Dark grey-black fissile shale, very $r$ lch in framboids of pyrite, glauconite absent.

The sample has a very high content of organic matter, most liptinite, but also large amounts of pseudovitrinite and huminite/vitrinite, fow inertinites (micrinite).

In blue light much fine-grained liptinite is seen. Many streaks of bituminite (dull brown-orange fluorescence and greenish inclusions), some sporinite (yellow-orange eluorescence), serveral alginites (Tasmanites with greenlsh-yellow fluorescence) and alginite fragments. 
$6430^{\circ}$ Fferrintslev Formation (F-4 Member)

Dark grey-black fisslle shale, very rich in framboids of pyrite, glauconite absent.

The sample has a moderate-high content of organic matter, most liptinite, only swall amounts of pseudovitrinite and huminite/vitrialte and inertinite.

In blue light much very fine grained liptinite is seen (1ike In 937A), most bituminite (brownish-orange Pluorescence with greenish fluorescing inclusions), some sporinite (orange fluorescence) and fow alginites (Tasmanites with greenish-yellow fluorescence).

939A $6490^{\circ}$ Ejerritslev Formation (F-3 Member)

Like $938 \mathrm{~A}$.

240A $6550^{\circ}$ Ejerritslev Formation (F-3 Member)

Like $938 \mathrm{~A}$.

$241 \mathrm{~A} 6610^{\circ}$ Ejerritslev Formation (F-3 Member)

Like 938A, but moderate organic content, liptinite (bituminite) predominant, fow very fine grained huminite/vitrinite particles, some are lower reflecting ulminite types.

242A $6670^{\circ}$ Fjerritslev Formation (F-3 Member) Like $941 \mathrm{~A}$.

243A $6730^{\circ}$ Fjerritslev Formation (F-3 Member) Like $941 \mathrm{~A}$.

244A $6790^{\circ}$ Ejerritslev Formation (F-3 Member) Like $941 A$.

245A $6850^{\circ}$ Fjerritslev Formation (F-3 Member) Like $941 \mathrm{~A}$.

$24646910^{\circ}$ Pjerritsiev Formation (F-3 Menber) Groy and brown shaly claystone, pyrite erequent, no glauconite.

The sample has a moderate content of relatively coarse grained organic partioles (some long ulminites up to $200 \mathrm{~m})$. The oorposition of the organle matter like 941A, but somewhat wore pseudovitrinite and hueinite/vitrinite.

247A $6970^{\circ}$ Fferritslov Formation (F-3 Member) Like $946 \mathrm{~A}$.

2484 7030. Fjerritslev Formation (F-3 Member) Grey-brown shaly claystone, glauconite absent, pyrite (small stens) rare.

The sample has a moderate content of organic matter, most pseudovitrinite and huminite/vitrinite, less ilpeinite. 
Blue :ight shows a low liptinite content (dull brown-orange) or no fluorescence, some bituminite and sporinite.

949A $7090^{\circ}$ Fjerritslev Formation (F-3 Member)

Like $948 \mathrm{~A}$, besides some large huminite/vitrinite with cellular structure (some telinites contain resinite), a few alginites (yellow fluorescence).

$950 \mathrm{~A} 7150^{\circ}$ Fjerritslev Formation (F-3 Member) Like $949 \mathrm{~A}$.

$951 \mathrm{~A} 7210^{\circ}$ Fjerritslev Formation (F-3 Member)

Grey shaly claystone, glauconite rare, pyrite rare.

The sample shows a moderate content of organic matter, most consisting of pseudovitinite and some. liptinite, less true huminite/vitrinfte (often lower reflecting types, can be coarse grained).

Blue light shows a moderate-low liptinite content, wost unidentiflable liptodetrinites some sporinites (orange fluorescence) and bituminite.

252A $7270^{\circ}$ Fjerritslev Formation (F-2 Member)

Like 951A, but pseudovitrinite dominant. Some very coarse grained cuttings (? cavings).

253A $7330^{\circ}$ Fjerritsley Formation (F-2 Member) Like $952 \mathrm{~A}$.

$954 \mathrm{~A} 7390^{\circ}$ Fjerritsler Formation (F-2 Member) Grey shaly claystone, probably like 915A, but also some different coarse grained cuttings and coaly particles (? cavings).

The sample shows a moderate content of organic matter, dowinated by pseudovitrinite and alwost equal amounts of huminite/vitrinite, a fow inertinites, almost no ilptinite.

Blue light shows a very low liptinite content, besides some liptodetrinites only a sew sporinites and bituminites can be recognized.

255A $7450^{\circ}$ Fjerritslov Foration (F-2 Member) Like $954 \mathrm{~A}$.

256A $7510^{\circ}$ Fjerritsiev Forwation (F-2 Member) Like $954 \mathrm{~A}$.

257A $7570^{\circ}$ Fjerritslev Formation ( $F-1$ Member) Dark grey shale, glauconite absent, frambolds of pyrite.

The sample has a moderate-low content of organic matter, wost pseudovitrinite (often showing oxidation rides and shrinkage cracks, probably due to reworking) and some liptinite. Only a fow small whisps of true huminite/vitrinite and some small inertinite eragments. 
Blue light shows some liptinite with varying Pluorescence, most small liptodetrinites (yelloworange fluorescence), a few sporinite (orange fluorescence) and streaks of bituminite. A fow alginites (Tasmanites, yellow fluorescence) probably in cavings.

258A $7530^{\circ}$ Fjerritslov Formation (F-1 Member)

like $957 \mathrm{~A}$.

959A $7690^{\circ}$ Ejerritslev Eormation ( $F-1$ Member)

Dark grey shale, glauconite rare, pyrite "tissues".

The sample has a moderate-low content of fine gralned organic particles, highly dominated by pseudovitrinite (some showing reworking, oxidation rims and shrinkage cracks), only few liptinlte and huminite/vitrinite particles and a fow inertinites (sclerotinite and fusinite).

Blue light shows a low liptinite content of small Ilptodetrinites (yellow-orange fluorescence), a few sporinite (dull orange-brown (luorescence) and very few streaks of bituminite.

960A $7750^{\circ}$ Ejerritslev Formation (F-1 Member) Like 959A.

961A $7810^{\circ}$ Ejerritslev Formation (F-1 Momber) Like $959 \mathrm{~A}$.

262A $7870^{\circ}$ Ejerritslev Formation (F-1 Member) Like 959A.

963A $7930^{\circ}$ Fjerritslev Formation (F-1 Member) Like 959A.

264 A $7990^{\circ}$ Ejerritslev Formation (F-1 Member) Like 959A.

965 A $8050^{\circ}$ Fforritsler Foration (F-1 Moaber) Dark groy shele, slauconite and pyrite (rhomble) rare.

The sauple has a moderate content of organic matter, nost pseudovitrinlte (often showing reworking, shrinkage cracks and oxidation rias) and some angular hualnite/vitrinfte, fow Inertinites (sclerotinite) and liptinite.

Blue light shows a low content of liptinite, wost structured liptodetrinites and a little bituminite, fow alginites and sporinites.

966A $8110^{\circ}$ Fjerritslev Formation (F-1 Member)

Like $965 A$. 
968A $8230^{\circ}$ Fjerritslev Formation (F-1 Member)

Dark grey shale with some coarse quartz-grains and dark finely laminated sand/siltstone with coaly stringers.

The sample has a moderate-low content of organic matter, with a composition like 965A, but the coarse grained cuttings more like $970 \mathrm{~A}$.

969A $8290^{\circ}$ Ejerritslev Formation (F-1 Member) Like 968A.

$970 \mathrm{~A} 8350^{\circ}$ Fjerritsiev Formation (F-1 Member)

Dark Laminated sand/siltstone with coaly stringers and dark grey shale, glauconite rare, pyrite common. The sample has a moderate content of relatively coarse grained angular and gnarled organic particles, most consisting of pseudovitrinite and huminite/ vitrinite (often bituminous), very little liptinite and inertinite.

Blue light shows a very low content of liptinite, very tow of sporinite (brownish-orange fluorescence), resinite, bituminite and some liptodetrinites

971A $8410^{\circ}$ Fjerritslev Formation (E-1 Member)

Like 970A..

272A $8470^{\circ}$ Gassum Formation

Like $970 \mathrm{~A}$.

273A $8530^{\circ}$ Gassum Formation

Different lithologies, grey shale and coarse grained sandstone with coal particles, feldspar, kaolinite, white and brown mica. Gauconite rare pyrite common. The sample has a moderate-high very coarse grained organic content with a composition like $970 \mathrm{~A}$ and besides a fow large coal grains (up to $1 / 2 \mathrm{~mm}$ in diameter) (most desmocollinite with sporinite, corpocollinite).

Blue light shows a rather low but varied content of liptinite, especially of sporinite (orange eluorescence) besides liptodetrinites and bituminite, a fow resinites, cutinite and ?alginite.

274 A $8590^{\circ}$ Cassum Formation

Like $973 \mathrm{~A}$, but more einegrained.

975 A $8650^{\circ}$ Gassum Formation

Same cutting lithology as 973 A (very coarse grained sandstone), besides some carbonate cuttings.

The sample shows a varied content of organic matter, like $973 \mathrm{~A}$, besides in the carbonate cuttings: many angular huminite/vitrinite and pseudovitrinite, some inertinite and liptinite.

Blue light shows a moderate content of liptinite, most bituminite. 
$8710^{\circ}$ Gassum Formation

Dark grey shale and yellowlsh fine grained sandstone

with coaly particles, glauconite rare, pyrite common.

The sample has a moderate content of coarse grained organic mattor. Many angular huminite/vitrinite and pseudovitrinlte but almost equal amount of liptinite.

Blue light shows a moderate content of liptinite, wuch sporinite (orange eluorescence) and bituminite, a fow resinites and cutinite (?) besides some liptodetrinites.

977A $8770^{\circ}$ Gassum Formation

Like 976A, but lower organic content (some "clea" coarse grained sandstone cuttings without organic material).

$8830^{\circ}$ Gassum Formation

Many very different cuttings, light sandstone, redgreen mottled claystone, dark claystone, white carbonates (? cavings).

The sample has in average a low organic content, but composition is difficult to estimate.

979A

$8890^{\circ}$ Gassum Eormation

Like 978A.

$8950^{\circ}$ Gassum Formation

Different lithologles, light coarse grained sand and siltstone (with feldspar and kaolinite) dark shale and some mottled red-green claystone. Glauconite absent, pyrite rare.

The sample has a varying but gererally rather low content of organic matter, largely dominiated by psoudovitrinite and few huminite/vitrinite and very few liptinites.

Blue light shows alnost no liptinite, a fow recognizable sporinites (dark orange-red (Iuorescence) baldes a fow 11 ptodetrinites.

$98119020^{\circ}$ Gassum Foraction

Llke 980A.

$9080^{\circ}$ Vinding Formation

Dark shale, some sand/siltstone with coaly stringers and carbonates. Pyrite and glauconite rare.

The sample has a moderate-low organlc content, most pine-grained angular huminite/vitrinite and pseudovitrinite, but also some liptinite.

Blue light shows a low liptinite content, sporinite (orange-red Pluorescence), small liptodetrinites and few alginites (yellow fluorescence). 
Dark grey and brownish shale, dark mottled carbona-

tes. Glauconite absent, pyrite common.

The sample has a low organic content, some liptinite often associated with small pyrites and a few huminite/vitrinite and pseudovitrinite.

Blue light shows a low liptinite content, most small liptodetrinites and alginites (yellow-orange fluorescence), (ew sporinites.

985A $9250^{\circ}$ Vinding Formation

Dark grey-black and brownish shale, dark mottled carbonates. Glauconite absent, pyrite common.

The sample generally has a moderaterlow organic content, dominated by liptinite and only a few pseudovitrinite and huminite/vitrinite.

Blue light shows a low iiptinite content, most alginite (tousled Botryococcuslike with yellow-orange fluorescence) and some liptodetrinites. In a lew cuttings the liptinite content is very high consisting of large Botryococcus like and alginite pragments with bright yellow eluorescence.

286A $9320^{\circ}$ Vinding Formation Missing

987A $9380^{\circ}$ Oddesund Formation Light gre claystone and siltstone, few carbonates, sowe cavings. Glauconite absent, pyrite common.

The saaple has a very low content of very suall (usually < 5 m) organic particles, some liptinite and some pseudovitrinite and huminite/vitrinite (many lower reflecting, ? cavings).

Blue light shows a few liptinites, small liptodetrinites and sporinite (orange-red fluorescence).

288A $9440^{\circ}$ Oddesund Formation

Like $987 \mathrm{~A}$. 
Bailey, N.J.L., Jobson, A.M. \& Rogers, M.A., 1973. Bacterial degradation of crude oil; Comparison of field and experimental data. Chem. Geol., 11, 203-221.

Balling, N., 1978: Geofysiske metoder til lokalisering af geotermiske energiressourcer. Dansk geol. For. Arsskr., $1977,13-27$.

Balling, N., 1979: Subsurface temperatures and heat flow estimates in Denmark. In: Cermak, V. \& Rybach, 1. (eds.): Terrestrial heat flow in Europe. Springer Verlag, 161-171.

Bernard, P.C. \& Cooper, B.S., 1981: 011s and source rock of the North Sea area. In: Illings, L.V. \& Hobson, G.D. (eds): Petroleum Geology of the continental shelf of north-west Europe. Heyden \& Son Ltd. for Inst. of Petroleum, London, 169-175.

Bertelsen, F:, 1978: The upper Triassic - lower Jurassic Vinding and Gassum Formation of the Norwegian-Danish Basin. Danm. geol. Unders., Ser. B, 3, 1-26.

Bertelsen, F., 1980: Lithostratigraphy and depositional history of the Danish Triassic. Danm. geol. Unders., Ser. B, 4, 1-59.

Bostick, N.H., 1974: Phytoclasts as indicators of thermal metamorphism, Franciscan Assemblage and Great Valley Sequence (upper Mesozolc), California. Geol. Soc. America Spec. Paper, 153, 1-17.

Bostick, N.H., 1979: Microscopic measurements of the level of catagenesis of solid organic matter in sedimentary rocks to aid exploration for petroleum and to determine former burial temperatures. A review. Soc. Econ. Paleont. Miner., Spec. Pubi., 26, 17-43.

Bray, E.E. \& Evans, E.D., 1961: Distribution of n-paraffins as a clue to recognition of source beds. Geochim. Cosmochim. Acta, 22, 2-15.

Brooks, J.D., 1969: Isoprenoid hydrocarbons in coal and petroleum. Nature, 222, 257.

Brooks, J. (ed.), 1981: Organic maturation studies and fossil fuel exploration. The British National Oil Corporation, Glasgow, 1-441. 
Christensen, O.B., 1974: Marine communications through the Danish Embayment during uppermost Jurassic and lowermost Cretaceous. Geoscience and Man, 6, 99-115.

Cornford, C., 1984: Source rocks and hydrocarbons of the North Sea. In: Giennie, K.W. (ed.): Introduction to the petroleum geology of the North Sea. Blackwell Scientific Publications, 172-204.

Damtoft, K., Andersen, C. \& Thomsen, E., 1987: Prospectivity and hydrocarbon plays of the Danish Central Through. In: Brooks, J. and Glennie, K. (eds.): Petroleum Geology of North west Europe, Graham \& Trotman, 403-417.

Deroo, G., Tissot, B., McCrossan, R.G. \& Der, F., 1974: Geochemistry of heavy oils of Alberta. Canadian Soc. Petrol. Geol. Memoir 3. Calgary, Canada: Stacs Data Services, 148-167.

Didyk, B.M., Simoneit, B.R.T., Brassel, S.C. \& Eglington, G., 1978: Organic geochemical indicators of paleoenvironmental conditions of sedimentation. Nature, 272, 216-222.

Dow, W.G., 1977a: Kerogen studies and geological interpretations. J. Geochem. Expl., 7, 79-99.

Dow, W.G., 1977b: Petroleum source beds on continental slopes and rises. AAPG Bull., 62, 1584-1606.

Ensminger, A. \& Albrecht, P., 1978: Rearranged steranes in sediments and crude oil. Tetrahedron Lett., 18; 1575-1578.

Gehmann, H.M. Jr., 1962: Organic matter in 1imestones. Geochim. Gosmochim. Acta, 26, 855-897.

Glennie, K.W., 1984: Introduction to the petroleum geology of the North Sea, Blackwell Scientific Publication, 1-236.

Hagemann, H.W. \& Hollerbach, A., 1980: Spektralfluorimetrische Analysen von Sediment-Extrakten. Erdol u. Kohle, 33, 577 .

Hagemann, H.W. \& Hollerbach, A., 1981a: Spectral Pluorometric analysis of extracts - a new method for the determination of the degree of maturity of organic matter in sedimentary rocks. Bull. Centres Rech. Explor.-Prod. ElfAquitaine, 5, 2, 635-650.

Hagemann, H.W. \& Hollerbach, A., 1981b: The spectral fluorometric analyses of the soluble organic matter applied. to hydrocarbon source rock evaluation. Advances in organic geochemistry 1981, Wiley, 72-75.

Huc, A.Y., 1980: Origin and formation of organic matter in recent sediments and its relation to kerogen. In: Durand, B. (ed.): Kerogen, Technip, 445-474. Hunt, J.M., 1968: How oil and gas form and migrate. World
Oil, 167, 140-150. 
Hunt, J.M., 1972: Distribution of carbon in crust of earth. AAPG Buli., 56, 2273-2277.

Hunt, J.M. 1979: Petroleum geochemistry and geology. W.H. Freeman and Co., 1-617.

Hutton, A.C., Kantsler, A. J., Cook, A.C. \& McKirdy, D.M., 1980: Organic matter in oil shales. APEA, $1,120,44-67$.

Koch, J.0., 1983: Sedimentology of middle and upper Jurassic sandstone and reservoir of Denmark. In: Raasschieter, J.P.H. \& Reijers, T.J.A. (eds.): Petroleum geology of the southeastern North Sea and the adjacent onshore areas. The Hague, 1982, Geol. Mijnb., 62, 115-129.

Larsen, G., 1966: Rhaetic-Jurassic-lower Cretaceous sediments in the Danish Embayment. Danm. geol. Unders. II række, 91, 1-127.

Lijmbach, G.W.M., 1975: On the origin of petroleum. 9th World Petr. Congress, Tokyo, 2, 357-369.

Lindgreen, H. \& Thomsen, E., 1982: Investigations on the source rock potential of the Danish onshore area. Danm. geol. Unders. 1-91.

Mackenzie, A.S., 1984: Applications of biological markers in petroleum geochemistry. In: Brooks, J. \& Welte, D. (eds.): Advances in petroleum gochemistry, 1, Academic Press, $115-214$.

Mackenzie, A.S. \& Maxwell, J.R., 1981: Assessment of thermal maturation in sedimentary rocks by molecular measurements. In: Brooks, J. (ed.): Organic maturation studies and fossil fuel exploration, Academic Press, 239-254.

Madsen, L., 1975: Approximate geothermal gradients in Denmark and the Danish North Sea sector. Danm. geol. Unders., Arbog 1974, 5-16.

Madsen, L., 1978: Geotermisk energi i Danmark - en geologisk vurdering. Dansk geol. Foren. Arsskr., 1977, 29-40.

McRirdy, D.M., Cox, R.E., Volkman, J.K. \& Howell, V.J., 1986: Botryococcane in a new class of Australian nonmarine crude olls. Nature, 320, 57-59.

Michelsen, 0., 1975: Lower Jurassic biostratigraphy and ostracods of the Danish Embayment. Danm. geol. Unders., II Række, 104, 1-287.

Michelsen, 0., 1978: Stratigraphy and distribution of Jurassic deposits of the Norwegian-Danish Basin. Danm. geol. Unders., Ser. B, 2, 1-28. 
Michelsen, 0., Saxov, S., Leth, J.A., Andersen, C., Balling, N., Breiner, N., Holm, L., Jensen, K., Kristiansen, J.I., Laier, T., Nygaard, E., Olsen, J.C., Poulsen, K.P., Prisholm, S., Raade, T.B., Sorensen, T. R. \& Wurtz, j., 1981: Kortlegning af potentielle geotermiske reservoirer $i$ Danmark, Danm. geol. Unders., Ser. B, 5, 1-78.

Michelsen 0., (ed.) 1982: Geology of the Danish Central Graben, Danm. geol. Unders., Ser. B, 8, 1-133.

Michelsen, 0. 1986: The Danish pre-Tertiary Lithostratigraphy. Danm. geol. Unders., Internal report no. 12.

Ottenjann, K., 1980: Spektrale Fluoreszens-Mikrophotometrie von Kohlen und Olschiefern. Leitz-Mitt. Wiss. u. Techn. (Wetzlar), VII, 282-272.

Ottenjann, K., 1981/82: Verbesserungen bei der mikro-photometrischen Fluoreszenzmessung an Kohlenmaceralen. ZeissInform, Oberkochen, $26,40-46$.

Ottenjann, K., Teichmüller, M. \& Wolf, M., 1974 : Spektrale Fluoreszenz-Messungen an Sporiniten wit Auflicht-Anregung, eine mikroskopische Methode zur Bestimmung des Inkohlungsgrades gering inkohlter Kohlen. Fortschr. Geol. Rheinld. u. Westf., $24,1-36$.

Ourisson, G., Albrecht, P. \& Rohmer, M., 1979: The hopanoids. Paleochemistry and blochemistry of a group of natural products. Pure Appl. Chem., 51, 709-729.

Ourisson, G., Albrecht, P. \& Rohmer, M., 1979: The microbial origin of fossil fuels. Sci. Am. $251(2), 44-51$.

Piller, H., 1978: Verfahren zur Bestimmung der spektralen Verteilung relative Fluoreszenz-Intensitaten. Zeiss Druckschr. A 41-823.2-d, Oberkochen.

Powell, T.G. \& McKirdy, D.M., 1975: Geological factors controlling crude oll composition in Australia and Papua, New Guinea. AAPG Bull., 59, 1176-1197.

Schmidt, B.J., 1985: A coal petrographic source rock evaluation of the Rhaetic-Jurassic-lower Cretaceous sediments of the Børglum 1 and Uglev 1 wells, Denmark. Bull. geol. Soc. Denmark, 33, 239-252.

Seifert. W.R. \& Molddowan, J.M., 1980: The effect of thermal stress on source-rock quality as measured by hopane sterochemistry. In: Douglas, A.G. \& Maxwell, J.R. (eds.): Advances in organic geochemistry, Pergamon Press, 229-237.

Stach, E., Mackowsky, M. -TH., Telchmuller, M., Taylor, G.H., Chandra, D. \& Telchmuller, R., 1975: Stach's Textbook of coal petrology (2.nd ed.), Gebrüder Bornträger, $1-428$.

Stach, E., Mackowsky, M.-Th., Teischmuller, M., Taylor, G.H., Chandra, D. \& Teichmulier, R., 1982: Stach's textbook of coal petrology (3.rd ed.), Gebrüder Bornträger, $1-535$. 
Teichmüller, M., 1979: Die Diagenese der kohligen Substanzen in den Gesteinen des Tertiärs und Mesozoikums des mittleren Oberrhein-Grabens. Fortschr. Geol. Rheinl. Westf., $27,19-50$.

Teichmüller, M., 1982: Origin of the petrographic constituents of coal. In; Stach, E. et al.: Stach's textbook of coal petrology, 3.rd ed., Gebrüder Bornträger, 219-294.

Teischmüller, M. \& Durand, B., 1983: Fluorescence microscopical rank studies on liptinites and vitrinites in peat and coals, and comparison with results of the rock-eval pyrolysis. International Journal of Coal Geology, 2, $197-230$.

Teichmüller, m. \& Ottenjann, K., 1977: Liptinite und lipoide Stoffe in einem Erdolmuttergestein. Erdol u. Hohle, 30, $387-398$.

Teichmüller, M. \& Teichmüller, R., 1966: Geological causes of coalification. In: Given, P. (ed.): Coal science, Adv. Chem. Ser., 55, 133-155. Am. Chem. Soc.

Teichmüller, M. \& Wolf, M., 1977: Applications of Pluorescence microscopy in coal petrology and oil exploration. J. Microscopy, 109, 49-73.

Thomsen, E., Lindgreen, H. \& Wrang, P., 1983: Investigation on the source rock potential of Denmark. In: Kaaschieter, J.P.H. \& Rejers, T.J.A. (eds.): Petroleum geology of the southeastern North Sea area and the adjacent onshore areas, 1982, Geol. Mijnb., 62, 221-239.

Thomsen, E., Damtoft, K. \& Andersen, C. 1987: Hydrocarbon plays in Denmark outside the Central Through. In: Brooks, J. and Glennie, K. (eds.): Petroleum Geology of North west Europe, Graham \& Irotman, 375-388.

Tissot, B., Califet-Debyser, Y., Deroo, G. \& Oudin, J.L., 1971: Origin and evolution of hydrocarbons in early Toarcian shales, Paris Basin, France, AAPG Bull., 55, $2177-2193$.

Tissot, B.P. \& Welte, D.H., 1984: Petroleum formation and ocurrence, Springer Verlag, 1-538.

Vandenbrouke, M., 1980: Structure of kerogens as seen by investigations on soluble extracts. In; Durand, B. (ed.): Kerogen Technip, $415-433$.

Van Dorsselaer, A., Ensminger, A., Spyckerelle, C., Dastillund, M., Sieskind, 0., Arpino, P., Albrecht, P., Ourisson, G., Brooks, P.W., Gaskell, S.J., Kimble, B.J., PhIlip, R.P., Maxwell, J.R. \& Eglington, G., 1974: Degraded and extended hopane derivatives ( $C-27$ to $C-35$ ) as ubiquitous geochemical markers. Tetrahedron Lett., 14 , $1349-1352$. 
Van Gijzel, P., 1981: Applications of the geomicrophotometry of kerogen solid hydrocarbons and crude oils to petroleum exploration. In: Brooks, J. (ed.): Organic maturation studies and fossil fuel exploration. The British National Oil Corp., Glasgow, 351-375.

Waples, D., 1980: Organic geochemistry for exploration geologists, Burgess Publ. Co., 1-151.

Well Data Summary Sheets 1981: Volume 2. The Geological Survey of Denmark. 
The source rock potential of the Mesozoic sediments in the Hyllebjerg-1 well is assessed in this paper.

The methods used encompas vitrinite reflectance measurements, spectral flourescence measurements, Gas Chromatography and mass spectrometry of Biomarkers. 